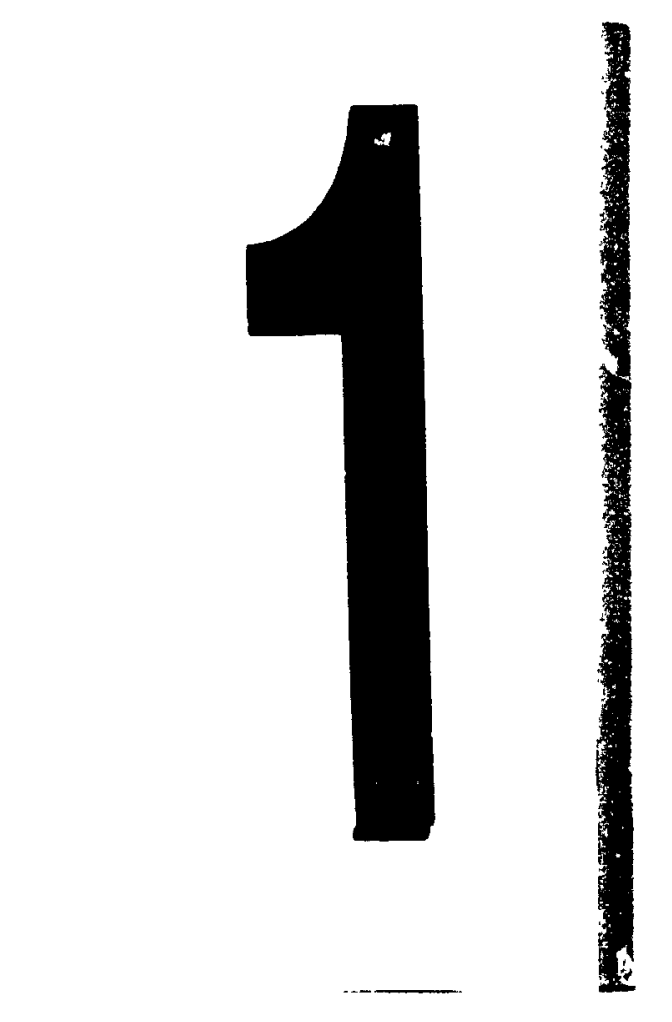

PM-1 31/2" 4 " PHOTOGRAPHIC MICROCOPY TARGET NBS 1010a ANSIIISO "2 EQUIVALENT

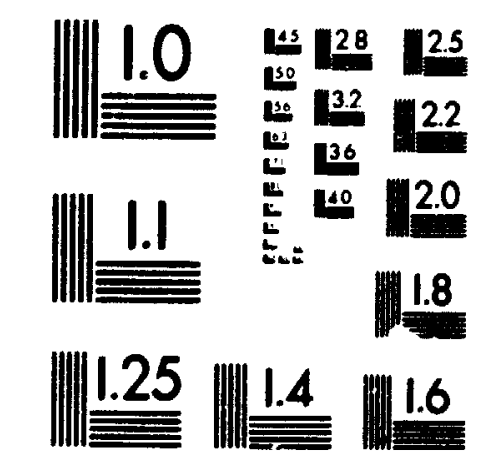

PRECISIONEm RESOLUTION TARGETS

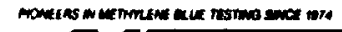


Acquisitions and

Bibliographic Services Branch

395 Wellington Street

Ottawa, Ontanio

KIA ON4
Bıbliothèque natıonale

du Canada

Direction des acquisitions et

des services bibliographiques

395. nue Wellington

Ottawa (Ontario)
NOTICE
AVIS
The quality of this microform is heavily dependent upon the quality of the original thesis submitted for microfilming. Every effort has been made to ensure the highest quality of reproduction possible.

If pages are missing, contact the university which granted the degree.

Some pages may have indistinct print especially if the original pages were typed with a poor typewriter ribbon or if the university sent us an inferior photocopy.
La qualité de cette microforme dépend grandement de la qualité de la thèse soumise au microfilmage. Nous avons tout fait pour assurer une qualité supérieure de reproduction.

S'il manque des pages, veuiliez communiquer avec l'université qui a conféré le grade.

La qualité d'impression de certaines pages peut laisser à désirer, surtout si les pages originales ont été dactylographiées à l'aide d'un ruban usé ou si l'université nous a fait parvenir une photocopie de qualité inférieure.

La reproduction, même partielle, de cette microforme est soumise à la Loi canadienne sur le droit d'auteur, SRC 1970, c. C-30, et ses amendements subséquents. 


\author{
AN EVALUATION OF THE ENVIRONMENTAL EDUCATION PROGRAM \\ OF THE CARLETON ROMPN CATHOLIC SCHOOL BOARD \\ by \\ SUSAN ANN SCRATCH, B.A., B.Ed. \\ A thesis submitted to \\ the Faculty of Grajuate studies and Research \\ in partial fulfilment of \\ the requirements for the degree of \\ Master of Arts \\ Department of Geography
}

\author{
Carleton University \\ ottawa, ontario \\ June 1992 \\ @copyright
}

1992, Susan Ann Scratch 
Natıonal Library

of Canada

Acquisitions and

Bibliographic Services Branch

395 Weltington Street

Ottawa. Ontario

KIA ON4
Biblıotheque natıonale

du Canada

Direction des acquisitions et des services bibliographiques

395. rue Wellington

Ottawa (Ontano)

KIAON4
The author has granted an irrevocable non-exclusive licence allowing the National Library of Canada to reproduce, loan, distribute or sell copies of his/her thesis by any means and in any form or format, making this thesis available to interested persons.
L'auteur a accordé une licence irrévocable et non exclusive permettant à la Bibliothèque nationale du Canada de reproduire, prêter, distribuer ou vendre des copies de sa thèse de quelque manière et sous quelque forme que ce soit pour mettre des exemplaires de cette thèse à la disposition des personnes intéressées.
The author retains ownership of the copyright in his/her thesis. Neither the thesis nor substantial extracts from it may be printed or otherwise reproduced without his/her permission.
L'auteur conserve la propriété du droit d'auteur qui protège sa thèse. Ni la thèse ni des extraits substantiels de celle-ci ne doivent être imprimés ou autrement reproduits sans son autorisation. 


\begin{abstract}
The undersigned recommend th the Faculty of Graduate studies and Research acceptance of the thesis
\end{abstract}

AN EVALUATION OF THE ENVIRONMENTAL EDUCATION PROGRAM

OF THE CARLETON ROMAN CATHOLIC SCHOOL BOARD submitted by Susan Ann Scratch, B.A., B.Ed. in partial fulfillment of the requirements for the degree of Masters of Arts

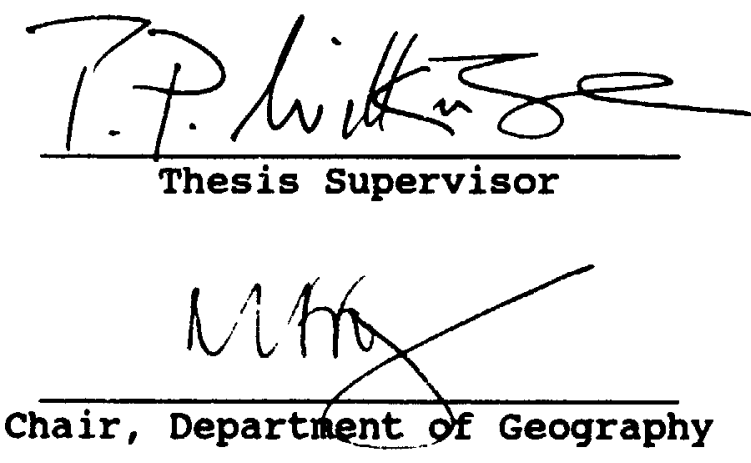

\author{
Carleton University \\ June 1992.
}


with the rise of environmental arareness in the late 1980 s environmental issues have begun appearing in the school curriculum. The following is an evaluation of the carleton Roman Catholic School Board's (CRCSB) environmental education program. The case study method, as described by Thomas (1989), was used to examine the environmental education program of the CRCSB in terms of the ontario Ministry of Education requirements. As well, satisfaction of the user group, the students, was examined.

As yet, the Ministry of Education has not developed a firm policy on environmental education. This notwithstanding, the CRCSB has made every effort to ensure that their students become environmentally conscious. The Board has established an environmental committee and seeks every available opportunity to heighten environmental awareness in its students and staff. Even so, the students are unsatisfied with the program and feel that far more reeds to be done by the Board. 
I would like to take this opportunity to thank the Carleton Roman Catholic school Board for agreeing to participate in this study and allowing me such free access to their staff and students. I would especially like to thank Vic D'Amico. He spent hours setting up interviews for me and answering questions.

I would also like to thank the people of the Geography department. Both the staff and my fellow students were very helpful every step of the way. Special thanks here go to Tom wilkinson, Iain Wallace and Mike Fox. without their assurances and patience this project would have been shelved long ago.

And of course there are my friends. To all those that I have complained to unceasingly for the last many months I am thankful. Walter, especially walter, Eliane, and Maureen you will never again hear me complain about how slowly this project is going. 
TABLE OF CONTENTS

Title Page $\ldots \ldots \ldots \ldots \ldots \ldots \ldots \ldots \ldots \ldots \ldots \ldots$ i

Acceptance sheet $\ldots \ldots \ldots \ldots \ldots \ldots \ldots \ldots \ldots \ldots \ldots$ i

Abstract ............................... ii

Acknowledgements $\ldots \ldots \ldots \ldots \ldots \ldots \ldots \ldots \ldots \ldots$ iv

Table of Contents ........................ v

List of Tables .......................... viii

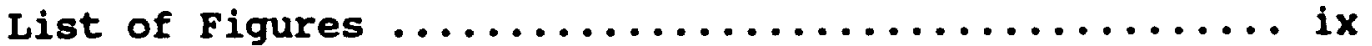

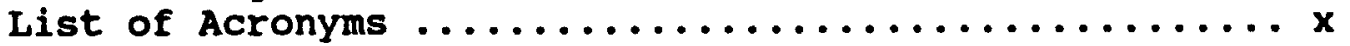

CHAPTER ONE: INTRODUCTION

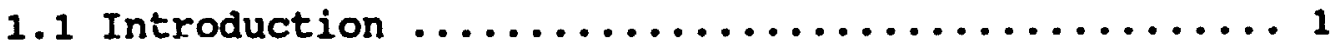

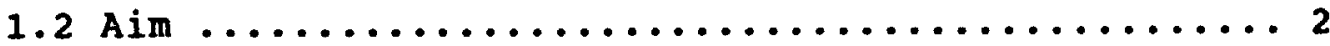

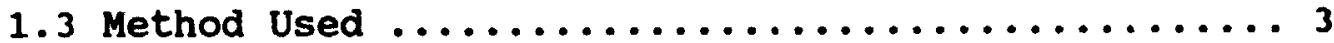

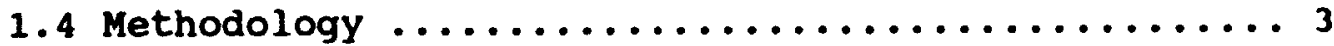

1.5 Thesis organization $\ldots \ldots \ldots \ldots \ldots \ldots \ldots \ldots \ldots \ldots \ldots$

CHAPTER TWO: THE ENVIRONMENTAL EDUCATION MOVEMENT

2.1 Defining Environmental Education ............ 7

2.2 A Short History of the Environmental Education Movement ......................... 8

2.3 Environmental Awareness in Canada ............ 11

2.4 Characteristics of Environmental Education ....... 14

2.5 Ultinate Educational Aims ................ 18

CHAPTER THREE: THE ENVIRONMENTAL EDUCATION PROGRAM OF THE ONTARIO MINISTRY OF EDUCATION

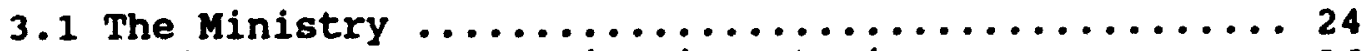

3.2 Environmental Education in Ontario ........... 26

3.3 The Primary and Junior Divisions ............ 29

3.4 The Intermediate and Senior Divisions ......... 34

CHAPTER FOUR: AN EVALUATION OF THE CARLE'TON ROMAN CATHOLIC SCHOOL BOARD'S ENVIRONMENTAL EDUCATION PROGRAM

4.1 The Board $\ldots \ldots \ldots \ldots \ldots \ldots \ldots \ldots \ldots \ldots \ldots \ldots \ldots \ldots \ldots \ldots$ 
4.2 The Environment Committee ................46

4.3 The Enviromental Education Program ............48

4.4 Results of the Board's Environmental

Questionnaire ....................... 51

CHAPTER FIVE: DATA ACQUISITION AND ANALYSIS

5.1 Data Acquisition ..................... 56

5.2 Research Design ....................... 58

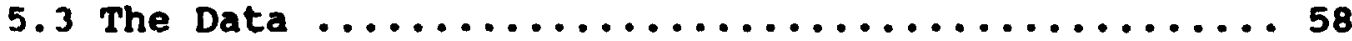

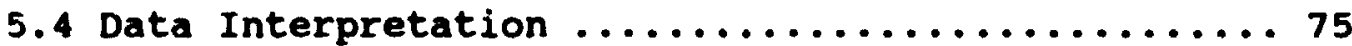

5.5 problems with Data Collection ............. 77

CHAPTER SIX: CONCLUSIONS AND RECOMMENDATIONS

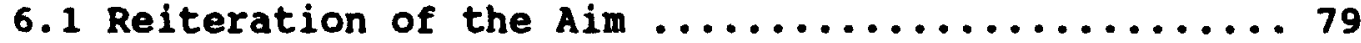

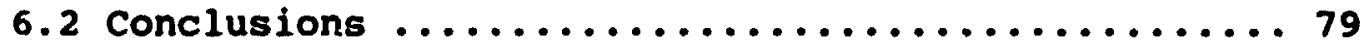

6.3 Recommendations ....................... 81

6.4 Limitations of the study ................... 83

6.5 Future Directions of Research ............... 84

APPENDIX A: Interview Guide $\ldots \ldots \ldots \ldots \ldots \ldots \ldots$

APPENDIX B: Ethics Committee Approval ............ 94

APPENDIX C: Request for Input From the Carleton

Roman Catholic School Board ..........96

APPENDIX D: The Goals of Education ............ 97

APPENDIX E: The Key Concepts of Environmental

Education .................... 101

APPENDIX F: Environmental Issues ............... 103

APPENDIX G: Environmental Learning Opportunitites

Afforded to Children in the Primary

and Junior Divisions 
APPENDIX H: List of Carleton Roman Catholic

School Board Schools - By School

Family ...................... 107

APPENDIX I: Goals of the Carleton Roman Catholic

School Board ......................110

APPENDIX I: Environmental Education at the carleton

Roman Catholic Sctool Board ..........113

APPENDIX K: Environment Questionnaire Administered by the Environmental Action Ad Hoc

Committee ....................133

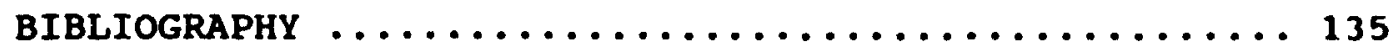

INTERVIEWS $\ldots \ldots \ldots \ldots \ldots \ldots \ldots \ldots \ldots \ldots \ldots \ldots \ldots \ldots \ldots \ldots$ 


\section{LIST OF TABLES}

5.1 Participant Involvement ................ 57

5.2 Environmentally Friendly Behaviour ..........6 63

5.3 How Can Teachers Become Better Informed on Environmental Issues ...................66 


\section{LIST OF FIGURES}

4.1 The Regional Municipality of ottawa-Carleton ..... 43

4.2 Schools of the CRCsB ....................44 44

5.1 Number of Years with the Board .............60

5.2 Do you consider yourself environmentally aware? ...........................61

5.3 Respondents' Ranking of the Board's Program ...... 70

5.4 Teachers' Ranking of the Board's Program ....... 71

5.5 Students' Ranking of the Board's Program ........ 72 


\section{LIST OF ACRONYMS}

CIDA: Canadian International Development Agency

CRCsB: Carleton Roman Catholic School Board

IDRC: International Development Research Centre

NGOs: non-governmental organizations

OAC: Ontario Academic Credit

OECD: Organization for Economic Cooperation and Develpoment

OS:IS: Ontario schools: Intermediate and Senior Divisions (Grades 7 - 12/0AC): Program and Diploma

Requirements, a publication of the Ontario Ministry of Education (1988).

PCC: Parent Communication Committee

PTA: Parent - Teacher Association

UN: United Nations

UNEP: United Nations Environment Program

UNESCO: United Nations Educational, Scientific and Cultural organization 
CHAPTER ONE

INTRODUCTION

\subsection{INTRODUCTION}

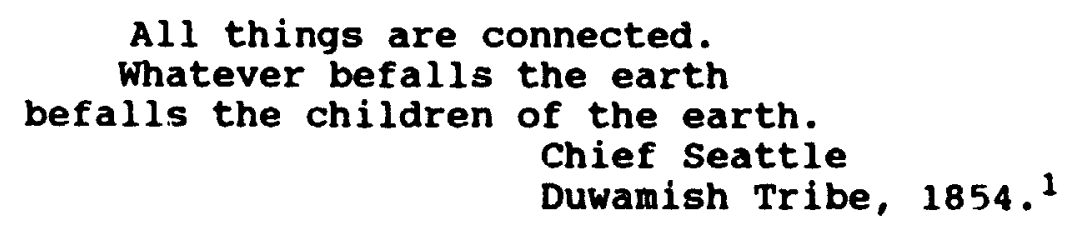

Chjef Seattle is quoted as having made this statement in 1854 but, it was not until the later part of the $1980 \mathrm{~s}$ that Canadians began to take the statement seriously. According to Michael Adams (1992), president of Environics Corporation, Canadians ranked the environment as the "number one issue" from 1988 to 1990 , in national poiss. Adams sees environmental issues as becoming part of the canadian "psyche" in the 1990s affecting everything we do in our daily lives.

Canadians are beginning to realize that their schools have not done a very effective job of teaching their children how to live "with" the environment. More and more pressure has been put on the ministries of education and the local school boards, by parents, to have environmental issues included in their children's curriculum (Lamarche, May 1991). This grassroots movement is slowly forcing change within the school systems of the nation.

1 Quoted from a poster produced by the British columbia Government. 
One of these school systems is examined in this paper. This paper is an evaluation of the environmental education program of the Carleton Roman Catholic School Board (CRCSB) .

The CRCSB was chosen for the study because it proved to be the most accessible board in the sttawa area, not because of any religious belief held, or not held by the researcher. The views expressed are not necessarily the views of the Board. These are the opinions of the individuals interviewed and may or may not be reflected in Board policies and practices.

\subsection{AIM}

The aim of this investigation is threefold: 1) to describe the environmental education program, both formal and informal, at the CRCSB; 2) to evaluate the content of the environmental education program of the CRCSB in terms of the Ministry of Education requirements; and 3) to determine whather or not the students, the users, are satisfied with the program.

At the outset only the first two points were considered. After data collection was begun it became apparent that the third issue needed to be addressed as well. There is little use in saying that a program has met Ministry standards if the persons who are supposed to be served by that program are not 
satisfied with it. Too often program evaluations stop with the program and do not examine user satisfaction.

\subsection{METHOD USED}

According to Thomas $(1989,4)$ case studies can be used when "the aim of the study is to provide understanding, rather than knowledge." In the case of an environmental education program the "evaluation will seek explanation of the program rather than the compilation of statistics" (Thomas 1989,4). The case study approach allows the researcher a great deal of flexibility. "It is particularly good at shedding light on all aspects of a program and helping to construct a picture of what was attempted and what has been achieved" (Thomas 1989,7 ). Several strengths of case studies, according to Thomas, are: the ability to represent diverse points of view and different interests and the ability to "uncover fundamental aspects of a program" (Thomas 1989,4).

\subsection{METHODOLOGY}

The approach taken in this evaluation was similar to that described by Thomas (1989). To begin with, the problem was defined by asking a series of questions: "what is the program"; "who is involved in the program"; and "what 
influences do they have?" Once the problem had been defined a thorough search of the relevant literature was undertaken. Upon completion of the literature search, it was decided that the research would be conducted using a case study method. A school board from the ottawa area, the CRCSB, was chosen to participate in the study. Persons from all levels of the Board were to be interviewed. At this point, an interview guide was designed. 2 The guide was then submitted to the university Ethics Committee for approval. 3

Once approval from the Ethics Committee was received the CRCSB was approached to participate in the study. A presentation was also made to the Board's Environmental Action Ad Hoc Committee asking if the committee had any particular issues it wished addressed in the research. 4

The CRCSB's policies and practices were researched and then interviews with persons from the Board were conducted. The data were then analyzed and simple descriptive statistics were used to describe the trends seen.

2 A copy of the interview guide is included in Appendix A.

3 Appendix B contains the letter of request sent to the university's Ethics Committee and the letter of approval received from the committee.

4 Appendix c contains a copy of the letter that was distributed at the Environment Committee meeting on the 1 st of May 1991. 


\subsection{THESIS ORGANIZATION}

Chapter 2 begins with a definition of environmental education, followed by a brief history of environmental education in an international context. Environmentalism is then addressed at a national level followed by a discussion of the nature of environmental education.

The environmental education program, as directed by the Ontario Ministry of Education, is examined in Chapter 3 . The Ministry of Education puts out curriculum guidelines and circulars for each grade and subject taught. These documents were examined and the sections that deal with environmental education are discussed.

The CRCSB's environmental education program is evaluated in chapter 4. The chapter begins with some descriptive details about the size of the Board and student population. The Board's Environmental Action Ad Hoc Committee (Environment Committee) and its policies concerning environmental education are examined. This is followed by a discussion of the Board's environmental education program and how it compares to Ministry expectations. The chapter concludes with a summary of an environmental questionnaire that was designed and distributed by the Environment committee.

Chapter 5 examines the data collected as a result of interviews with persons from the Board. Chapter 6 contains 
conclusions and recommendations as well as suggestions for further study. 
CHAPTER TWO

THE ENVIRONMENTAL EUUCATION MOVEMENT

To assist the reader in understanding the impetus behind some of the decisions the CRCSB has made in terms of environmental education, discussed in Chapter 4, this chapter briefly describes the history, characteristics and nature of environmental education.

\subsection{DEFINING ENVIRONMENTAL EDUCATION}

Environmental education is the process of recognizing values and clarifying concepts in order to develop skills and attitudes necessary to understand and appreciate the inter-relatedness among man, his culture, and his biophysical surroundings. Environmental education also entails practice in decision making and self-formulation of a code of behaviour about issues concerning environmental quality (Saveland 1976,4 ).1

The term "environmental education" became popular in the $1960 \mathrm{~s}$ (Disinger 1985, 1). Disinger describes environmental education as having evolved out of nature study, conservation education, and outdoor education. 2 Environmental education

1 Adopted by the first International working Meeting on Environmental Education in the School Curriculum, 1970. Taken from Jan Ceruvsky, p. 17, comprehensive Programmes of Environmental Education, Conference Document 33-6/KP/2, European Working Conference on Environmental Conservation Education, I.U.C.N., Morges, Switzerland, Nov. 1971.

2 Disinger $(1985,1)$ describes the emphasis of these predecessors as: "the natural environment, the pastoral environment, and the environment as the preferred venue for learning", respectively. These educational practices continue to exist today in much the same format as they always have. 
has taken the study of natural/pastoral environments, the "environmental education" of the past, and added the concept of human impact on natural environments.

2.2 A SHORT H'STORY OF THE ENVIRONMENTAL EDUCATION MOVERENT

Little attention was given to environmental consequences during the rapid growth and industrialization of the $1950 \mathrm{~s}$ and 60s. Industry, the major polluter, had few regulations and controls imposed upon it. At the time there was a notion that our resources were inexhaustible and we could continue economic growth indefinitely, without regard to environmental consequences.

An indication that something was amiss with our atmosphere was the London smog of 1952 which killed 4000 people (Biswas and Biswas 1982, 125). Slowly, other environmental concerns came to light, such as an increase in water pollution, lack of land-use pianning and increased noise levels.

In the last forty years several events have occurred to heighten the awareness of individuals. Rachel Carson's silent Spring (1962) was a turning point for many people. During the later part of the $60 \mathrm{~s}$ and early $70 \mathrm{~s}$ other books were written and governments began to take action. Environmental protection agencies were established and tougher regulations and policies were adopted (CIDA 1986C, 2). 
Biswas and Biswas $(1982,125)$ gauged the interest of the general public by comparing the number of articles on environmental issues published in The New York Times every year. During the ten year period 1960 to 1970 the number of articles published increased by slightly over 10008 .

Environmentalism, as an international movement, gained momentum in June of 1972. That summer the United Nations Conference on the Human Environment, the first of the United Nations (UN) mega-conferences, was held in stockholm (CIDA 1986c, 2). It recommended that

...the organizations of the United Nations ... should after consultation and agreement, take the necessary steps to establish an international programme in environmental education, interdisciplinary in approach, in school and out of school, encompassing all levels of education and directed towards the general public (UNESCO 1980, 19).

For the first time, world attention was focused on "indiscriminate development" and the threat that that development posed to "planetary life-support systems." It marked the beginning of a truly historic change in understanding: "there were limits to the earth's capacity to sustain development and provide essential resources" (CIDA $1986 \mathrm{c}, 2)$.

The Earthwatch Program and the United Nations Environment Program (UNEP) both resulted from the stockholm conference. Earthwatch is an international monitoring, research and exchange network. UNEP, based in Nairobi, Kenya, monitors emerging problems, assesses the risks and develops proposals 
for better environmental management. It advocates sustainable development, "development based on sound environmental principles and practices that protect the long-term socioeconomic development of populations" (CIDA 1986C,2).

A lack of cooperation before the 1972 United Nations Conference on the Human Environment encouraged the adoption of Recommendation 96 by the UN General Assembly. Recommendation 96 was developed at the 1972 conference in stockholm. It placed the responsibility for leadership with UNESCO and enjoined all other organizations to cooperate fully (Dyasi 1977, 45). As well, Recommendation 96 gave UNESCO the authority to "study innovations in general education and specialized training and to encourage the institution of courses and training periods at the regional and international levels" (Dyasi 1977, 45).

The first international exchange on environmental education took place in 1975. UNESCO and UNEP organized the Belgrade Workshop which was attended by specialists from sixty-five countries. It was followed in 1976 and 1977 by meetings of experts from the various regions of the world, and national or subregional meetings organized by Member states. The concepts relating to environmental education were thus established (UNESCO 1980, 19).

In 1983, the World Commission on Environment and Development was established by the United Nations General Assembly. The Commission was asked to study "the relationship 
between economic development and the global environment and to make recommendations about both that would guide countries in the early part of the next century" (Government of Canada $1990 a, 4)$. The Brundtland Report was tabled in 1987 under the title our Common Future: World Commission on Fnvironment and Development. The report deals, at length, with the concept of sustainable development, and promotes the idea "that resources must be treated on the basis of their future, as well as their present, value" (Government of Canada 1990a, 4).

We have come a long way from the fledgling environmental moversent of the 60s and early 70s. Take, for example, the number of countries having environmental agencies. In 1972 there were only 11 developing countries with environmental agencies, by the early 80's there were 102. Another indication of our progress is the number of non-governmental organizations (NGOS) involved in environmental issues. By 1986 there were 5000 NGOs registered with the Environmental Liaison Centre in Nairobi (CIDA 1986C, 2). Through NGOs and organizations like UNEP and UNESCO the average person is slowly being made aware of the environmental issues and how they, as individuals, affect the planet.

\subsection{ENVIRONMENTAL AWARENESS IN CANADA}

The Canadian economy relies heavily on its natural resources. Yet, there is growing evidence that we have not 
been meeting our environmental responsibilities (Government of Canada 1990a, 3). "Canadians use the most energy, drive the greatest distances, and create the most garbage on a per capita basis" (Hammill 1990, 16). These facts are associated with abuses which lead to pollution problems in our air, land, and water (Government of Canada 1990a, 3).

Even so, Canada played a large role in the organization of the 1972 stockholm Conference, the UN's first environment conference. Maurice strong, at the time president of CIDA, served as the chief organizer of the conference. The conference raised concern about many environmental issues that have only recently been "embraced" by political leaders. subsequently, Mr. strong founded and became the first executive director of UNEP (Ottawa citizen 1989, 3).

A second influential Canadian environmentalist is Jim MacNeill. MacNeill served as Secretary General to the World Commission on Environment and Development, the Brundtland Commission, for three years. Prior to this he spent 7 years as director of the Organization for Economic Cooperation and Development, based in Paris. In 1987 MacNeill moved to ottawa to establish a sustainable development program at the Institute for Research on Public Policy (Ottawa citizen, 1989, 3).

Many Canadians became sensitized to environmental issues in the 1970 s wen the government, the media and special interest groups began to popularize the issue. Interest 
continued to grow as the general public looked more and more for preventative measures instead of "react and cure" policies (CIDA 1986a, 5).

In part, as a reaction to public demand the Environment Minister, Robert R. de Cotret, released Canada's Greer:Plan on December 11th, 1990. The Green Flan is a "a comprehensive, \$3 - billion, five - year environmental action plan for Canadan (Government of Canada 1990b, 1).

Canada's Green Plan offers new policies, programs and standards to clean up, protect and enhance our land, water and air, our renewable resources, the Arctic, parks and wildlife, and to reduce waste generation and energy use. It also includes measures to maintain global environmental security. foster environmentally responsible decision-making and improve our emergency preparedness (Government of Canada 1990b, 1).

The entire essence of the plan can be boiled down to these two statements: "Sustainable development is what we want to achieve. The Green Plan sets out how we are going to achieve it..." (Government of Canada 1990a, 5).

The Green Plan looks to the government to provide "leadership" and to society as a whole to "produce the changes we need to meet the economic and environmental challeages of the 1990s and beyond" (Government of Canada 1990a, 5). The efforts of all Canadians are required to meet the overall national objective expressed in The Green Plan: "to secure for current and future generations a safe and healthy environment, and a sound and prosperous economy" (Government of Canada 199\%a, 9). 
In order to achieve this objective, we must be able to provide for Canada's "environmental and economic future by investing in science, education and technology" (Government of Canada 1990a, 15).

\subsection{CHARACTERISTICS OF ENVIROMMENTAL EDUCATION}

Environmental education is an integral part of the education process. It should be centred on practical problems and be of an interdisciplinary character. It should aim at building up a sense of values, contribute to public well-being and concern itself with the survival of the human species. Its force should reside mainly in the initiative of the learners and their involvement in action and it should be guided by both immediate and future subjects of concern (UNESCO 1981, 1).

Environmental education is more than a new course one adds to the curriculum. Its a way of life. The literature repeatedly points out four major themes that characterise environmental education: interdisciplinarity, community orientation, life-long education, and the problem-solving approach (Biswas and Biswas 1982, UNESCO 1980 and Kelly 1977). These are interwoven to give environmental education the foundation that it needs to work towards changing our society.

It has become clear that no single discipline can encompass the totality of the environment. The environment includes aspects of geography, history, biology, and mary other disciplines. These disciplines must be viewed as one cohesive working unit, much like the environment itself. Each discipline will approach a problem uniquely sut without some 
knowledge of the other disciplines the chances of solving this particular problem efficiently are slim (Biswas and Biswas 1982, 127).

More and more learning theory is incorporating the notion that "knowledge is not simply the juxtaposition of disparate elements but is rather the progressive coordination of the elements, each interacting with all the others" (UNEsco 1981 , 1). It is far more productive to integrate information than to teach it as distinctive parts. To illustrate with a very simple example, it is almost impossible to follow the politics of World War I without knowing something about the geography of Europe.

The environment, as a "teachable" topic, has entered the educational world at a time when the paradigm of interdisciplinarity is working its way into the classroom (Duquette, March 1991). The environment is the ideal topic on which to try out this new teaching paradigm. Can students learn better using this interdisciplinary approach? Will the interdisciplinary approach produce young adults who are better able to think for themselves? - These questions and many more like them will be answered in the coming years.

One of the important innovations emphasised by environmental education is the idea that environmental education should be community oriented. Students react best to studies in their local environment (UNESCo 1980, 28). One 
strategy, therefore, should be to get the students out of the classroom and into their environment.

It is undoubtedly in everyday community life and face to face with the problems there that individuals and social groups will come to feel concerned with the quality of the environment and will act with resolve and perseverance to preserve or improve it ('JNESCO 1980, 28).

To be effective environmental education should, by its very nature, be intended for all members of the community.

It should create in the public at large an awareness and a better understanding of environmental problems; it should provide the member's of certain occupational groups whose activities have a direct bearing on the environment with an appropriate grounding in environmental matters; and, lastly, it should train research workers and other professionals specializing in environment science (UNESCO 1980, 20).

"Since environmental education should be a lifelong process, available to all, it should be provided at all educational levels, both in ind out of school" (UNESCO 1980, 20). It is not something we can discuss in kindergarten and then never mention again. Environmental education must be taught and retaught until the environmental ethic becomes ingrained in the population. ${ }^{3}$ Yet, some educators are afraid that we could over teach environmental education, and feel that there needs to be a "happy medium" (Duggan, May 1991).

3 Vivian $(1973,8)$ believes that any environmental ethic must include three basic beliefs. They are:

1) people should have a reverence for all life;

2) people should respect the right of existence for all environments; and

3) people should accord the highest priority to environmental quality. 
Due to the diverse nature of environmental concerns problem-solving skills are seen as a necessary part of any environmental education program. Problem solving is not an easy process. It involves a whole series of skills and abilities that must be learned and internalized. The Ministry of Education, in its science is Happening Here publication (Ontario Ministry of Education 1988a, 43), has adopted the following problem-solving model:

A PROBLEM-SOLVING MODEL

STAGE

Exploring

Inquiring

Predicting

Planning and collecting

Deciding

Communicating

Evaluating

Applying
SOME FACILITATING QUESTIONS

What do we see? What do we hear? What is happening?

What questions could we ask to find out what to know (e.g., Which one is strongest? Why did the bulb light?

When...? What...? How...? Which...?)?

What do we think? How will we know?

How can we find out? What can we do? What will we need? Where should we look? Whom should we ask? How will we lynow?

What did we learn? What do we think now? What are we going to do now?

With whom should we share? Why should we share? What should we share? How can we share?

Did we find out what we wanted to? could we have done it differently?

How is this the same as... or different from...? What other questions could we ask?

(Ontario Ministry of Education 1988a, 43). 
This model has been adopted for elemeniary school children (5 to 12 years). Yet, Piaget felt that it was not until the formal operational stage (11 to 16 years) that children were able to develop skills at predicting and hypothesis testing (Sprinthall and Sprinthall 1987, 104). Is the educational system misapplying resources by trying to teach problem solving to young children (less than 11 years old), or can some of the skills involved be acquired at an early age (e.g. exploring and inquiring)? Regardless, the environmental problems we face today require more and more a problem-solving approach. As Biswas and Biswas $(1982,129)$ stated "there are not enough people who... are willing to innovate when applying theory to practice." Maybe introducing appropriate problem-solving skills at a young age is the answer.

\subsection{ULTIMATE EDUCATIONAL AIMS}

As stated in the Belgrade Charter ${ }^{4}$, environmental education seeks:

To develop a world population that is aware of, and concerned about, the environment and its associated problems, and which has the knowledge, skills, attitudes, motivations and commitment to work

${ }^{4}$ The Belgrade Charter was produced at the first International Environmental Education Workshop at Belgrade in October 1975. The charter "laid down the principles and established the guidelines for the world-wide environmental education of a generation which spans the earth" (UNEsCO $1976,1)$. 
individually and collectively toward solutions of current problems and the prevention of new ones (UNESCO 1976, 2).

This quotation sums up the goal of global environmental education quite well. This educational goal, as UNEsCo sees it, will be achieved through a series of objectives that focus on awareness, knowledge, attitudes, skills, and participation (UNESCO 1980, 71). Once a learner has achieved each of the educational objectives he or she will be environmentally educated, according to the UNESCo definition.

The primary aim of environmental education is "to enable human beings to understand the complex nature of the environment as this results from the interaction of its biological, physical, social, economic and cultural aspects" (UNESCO 1980, 23). Thus, environmental education must provide the learner with the knowledge and understanding of the elements listed above. It is hoped that through this learning process the student will gain a respect for and understanding of the resources our world offers, and learn to use them wisely.

Environmental education should also contribute to "an appreciation of the importance of the environment in economic, scicial and cultural development," or what has come to be known as "sustainable development", development "of ways of life conducive to a harmonious relationship with the environment" (UNESCO 1980, 23). 
Finally, environmental education should provide an understanding of "the economic, political and ecological interdependence of the modern world, where the decisions and behaviour of the variolis countries can have international repercussions" (UNESCO 1980, 69).

To achieve the above aims, not only must environmental education teach knowledge and methods, it must also teach values and attitudes. Only by learning environmental values and attitudes will the learner be able to understand and solve environmental problems. Even with this understanding changes in behaviour will only occur when "a majority of the members of a particular society have adopted more positive values" (UNESCO 1980, 24). Only once environmental activism is socially acceptable will a large number of the population begin to act. Increased education will not promote change if change is not introduced in a social context.

In general, the aim should be to inculcate, at every level of formal and non-formal education, the ability to acquire, analyse, synthesize, communicate, apply and evaluate existing knowledge on the environment (UNESCO 1980, 25).

This is a noble aim for a First world country where few people die of starvation. A sobering note was voiced by the Brundtland Commission when they reminded us that

... in terms of absolute numbers there are more hungry people in the world than ever before, and their numbers are increasing. So are the numbers who cannot read or write, the numbers without safe water or safe and sound homes, and the numbers short of woodfuel with which to cook and warm themselves. The gap between the rich and poor nations is widening... Poverty is a major cause and 
effect of global environmental problems (Brundtland $1988,2)$.

It is naive to believe that someone who does not have enough food to eat is going to be concerned about the environment. Their over-riding concern is how do they feed themselves and their families. "It is therefore futile to attempt to deal with environmental problems without a broader perspective that encompasses the factors underlying world poverty and international inequality" (Brundtland 1988, 2).

Disinger criticises environmental education in that it tends to take a negative perspective. "It seeks to capture attention and is generally successful in doing so, by focusing on what is wrong, not what is right, with science - technology - society - environment interactions as they exist, or are perceived to exist, in the real world" (Disinger 1985, 2). Environmental education has, unfortunately, not progressed to the stage where it can offer viable solutions to environment related problems (Disinger 1985,2 ).

Environmental education has thus far focused on "awareness and appreciation of environmental issues" and must, in the future, go beyond this if students are expected to take action. According to Hammill, president of the Environmental Educators' Provincial Specialist Association in British Columbia, two other objectives need to be met to motivate students to take action:

Students must gain sufficient understanding to be able to make rational decisions on the resolution of environmental issues. 
Students must have the means to take whatever action is required to resolve environmental issues (Hammill 1990, 16).

As Nicholson stated in his Keynote Address to the conference on environmental education held at the college of Technology, Farnborough, England in 1977. "...not being environmentally educated is simply not being educated" (Nicholson 1977, 5).

We need nothing short of a new global ethic - an ethic which espouses attitudes and behaviour for individuals and societies which are consonant with humanity's place within the biosphere; which recognizes and sensitively responds to the complex and ever-changing relationships betweell humanity and nature and between people (UNESCO 1976, 1).

This statement may seem rather dramatic but many environmentalists believe that if we do not start doing something soon we will have changed the Earth so much that no amount of education and effort will "set it to rights".

In nature there are balancing mechanisms: disease and fire for example. These mechanisms have not affected humankind on a large scale for decades because we have been able to develop new technologies to avoid them. But what if, just for argument sake, we say that our ideas have run out. Mother nature is catching up to us. Then what?

Even if predictions prove to be wrong, even if the environmentalist stance is overstated or exaggerated, we would be wise to live well within the means of the planet. Thus, there is a need for environmental education on a global basis. 
Individuals have to be made aware of the impact their actions have on their surroundings. They have to have knowledge and understanding to be able to choose the least harmful alternative. This said, it is hard to believe that the Ontario Ministry of Education has not developed a comprehensive environmental education policy. The following chapter describes what little has been undertaken by the Ministry in terms of environmental education. 
CHAPTER THREE

THE ENVIRONMENTAL EDUCATION PROGRAM OF

THE ONTARIO MINISTRY OF EDUCATION

\subsection{THE MINISTRY}

The Ontario Ministry of Education endeavours to design a publicly supported education system that will "provide the greatest possible opportunity for every student to develop as completely as possible his or her abilities and interests and to meet each student's special needs" (Ontario Ministry of Education 1989a, 2). This aim is achieved through programs that are designed to help individual learners "achieve their potential in physical, intellectual, emotional, social, cultural, and moral development" (ontario Ministry of Education 1989a, 3).

To facilitate the achievement of this aim the Ministry has laid out thirteen goals of education (Ontario Ministry of Education 1989a, 3), a common framework of learning opportunities that the schools should make available to its students. The goals of education consist of helping each student to:

1. develop a responsiveness to the dynamic processes of learning;

2. develop resourcefulness, adaptability, and creativity in learning and living;

3. acquire the basic knowledge and skills needed to comprehend and express ideas through words, numbers, and other symbols; 
4. develop physical fitness and good health;

5. gain satisfaction from participating and from sharing the participation of others in various forms of artistic expression;

6. develop a feeling of self-worth;

7. develop an understanding of the role of the individual within the family and the role of the family within society;

8. acquire skills that contribute to self-reliance

in solving practical problems in everyday life;

9. develop a sense of personal responsibility in society at the local, national, and international levels;

10. develop esteem for the customs, cultures, and beliefs of a wide variety of societal groups;

11. acquire skills and attitudes that will lead to satisfaction and productivity in the world of work;

12. develop respect for the environment and a commitment to the wise use of resources; and

13. develop values related to personal, ethical, or religious beliefs and to the common welfare of society (Ontario Ministry of Education 1989a, 3).1

The Ministry issues guidelines and circulars rather than detailed courses of study because it is felt that, to be effective, curriculum must reflect the needs of the particular pupils for whom it is planned. Thus, the Ministry provides direction and support and it becomes the responsibility of the local school boards to design programs that are "within the rationale of the provincial policy and at the same time reflect local needs and priorities" (Ontario Ministry of Education 1975,2$)$. It then falls to the school's staff to

1 For a description of each goal see Appendix $D$. 
plan classroom programs "specifically adapted to the children for whom they are responsible" (Ontario Ministry of Education $1975,2)$.

The individual teacher selects strategies, resources, and activities appropriate to the needs of individual learners. Each learner is then involved in "setting short-term objectives, in devising ways and means of accomplishing tasks, and in choosing activities" (Ontario Ministry of Education $1975,2)$.

The general policies of the educational program in Ontario are laid out in two documents: circular P1J1: Provincial curriculum Policy for the Primary and Junior Divisions of the Public and Separate Schools of ontario: The Eormative Years ${ }^{2}$ (Ontario Ministry of Education 1975) and Ontario Schools: Intermediate and Senior Divisions (Grades 712/OACs): Program and Diploma Requirements ${ }^{3}$ (Ontario Ministry of Education 1989a). These two documents are supported by more specific curriculum guidelines and circulars for each subject area.

\subsection{ENVIRONMENTAL EDUCATION IN ONTARIO}

The only information obtained from the Ministry, specifically dealing with environmental education, came in the

2 Commonly referred to as The Formative Years.

3 commonly referred to as osirs. 
form of an unpublished report by Lorne Smith (1991) of the Curriculum Policy Development Branch. The report is twelve pages long and describes, in very basic terms, what the Ministry expectations are with regard to environmental edication. 4

The twelfth goal of education, as stated in osiIs, is to: "develop respect for the environment and a commitment to the wise use of resources". Every teacher is, thus, expected to introduce environmental concepts into the curriculum as appropriate (Smith 1991, 1).

According to Smith "a wide range of environmentally related topics" are outlined in the Ministry curriculum documents. The documents specifically mentioned, as dealing with environmental issues, are: science is Happening Here (used in the Primary and Junior divisions), science, Grades 7 and 8 , and Geography Part $c$ : The Intermediate Division Program (Smith 1991, 1).

Smith $(1991,1)$ then goes on to note that at the secondary level students must "successfully complete a full credit course in Canadian Geography and two full credit courses in science" as partial fulfilment of a secondary School Graduation Diploma. In addition optional courses are available in Environmental Science, Environmental studies,

4 According to Mr. Smith (April 1992) this is the official Ministry policy on environmental education. The document has been distributed broadly throughout the ontario education system and is designed to help explain "who we are and what we do". 
Physical Geography, World Issues, Physics, Chemistry, Biology, Canadian Geography, and Science in Society.

Those environmental concepts which the Ministry feels are key concepts to environmental education and should be addressed in the curriculum are:

- the planet is a closed system

- renewable / non-renewable resources

- market forces

- human impact

- natural cycles

- resource management

- habitat

- food chain

- decision - making

- natural rehabilitation and regeneration

- reduce, reuse, recycle, and rethink

- respect for ail living things (Smith 1991, 9).5

Those environmental issues that the Ministry feels are relevant are:

- growth of the population

- global warming

- destruction of the ozone layer

- vanishing forests

- acid rain

- biotechnology

- environmental deterioration

- loss of genetic diversity

- soil degradation

- disappearance of prime agricultural land

- disappearance of wetlands

- waste disposal

- air quality

- water quality

- sustainable development

- distribution of wealth and food

- respect for living things (Smith 1991, 11).6

5 Appendix $\mathbf{E}$ contains a more detailed description of these concepts.

6 Appendix F contains a more detailed description of these issues. 
Along with scientific information the curriculum guidelines also emphasise the development of environmentally responsible attitudes and values. The "objective is to help students understand the scientific, personal and societal dimensions of environmental issues and to act accordingly" (Smith 1991, 1).

\subsection{THE PRIMARY AND JUNIOR DIVISIONS}

The Ministry of Education's policy document for the Primary and Junior Divisions is The Formative Years (Ontario Ministry of Education 1975). The Formative Years is a twentyfour page document that was published in 1975. It addresses all subjects taught from Kindergarten to Grade 6 (age 5 to 12 years).

In this document the Government makes a pledge to: support an education that develops basic skills, knowledge, and attitudes, that endeavours to provide a fuller life during a child's years in the Primary and Junior Divisions, and that endeavours to nurture every child's growth so that each may be able to continue his or her education with satisfaction and may share in the life of the community with competence (Ontario Ministry of Education 1975, 4).

From this pledge, it follows that the curriculum will provide each child with opportunities:

- to acquire the basic skills fundamental to his or her continuing education;

- to develop and maintain confidence and a sense of self-worth; 
- to gain the knowledge and acquire the attitudes that he or she needs for active participation in Canadian society;

- to develop the moral and aesthetic sensitivity necessary for a complete and responsible life (Ontario Ministry of Education 1975,4 ).

These general learning opportunities are then described in greater detail in The Formative Years. The section that is of particular interest is science and Geography.

The Science and Geography section states that Primary and Junior Division children will be given opportunities to:

Understand the environment, both in terms of the nature of its parts and of the patterns that characterize it as a whole

- develop an awareness of the natural environment and of how it affects and in turn is affected by human activities, past and present;

- develop an initial understanding of the relationships among natural things (e.g., the relationship between weather and erosion), among natural and manufactured things (e.g., between machinery and air pollution), and between people and things (e.g., between the quality of life and the automobile):

- perceive the development of patterns and relationships over time, such as the structurefunction patterns of living things, the interdependence of living things, and the relation of the form and structure of materials to properties and function:

- develop concepts basic to science, such as matter, mass, force, energy, time, temperature, change, interdependence, growth, and development (Ontario Ministry of Education 1975, 22).

These four points have been expanded on in the publication Science is Happening Here (Ontario Ministry of Education 1988a). 
The only time The Formative Years makes reference to the environment is in the section quoted above. The reader could "read between the lines" in other parts of the publication and expect that the environment is being discussed. One such section is the section on values. This section states that children in the Primary and Junior Divisions will be given opportunities to: "become aware of the values that Canadians regard as essential to the well-being and continuing development of their society" and "identify and analyse public value issues" (Ontario Ministry of Education 1975, 20). These two statements could be interpreted in such a way as to highlight the environmental angle. The question one needs to raise here is "are they?" Do the teachers read environmental education into these statements? This research will explore the extent to which statements such as this are interpreted, by the Board and, more importantly, its teachers, to have an environmental angle.

The Formative Years and science is Happening Here are quite inconsistent. The Formative Years refers to "Science and Geography" while the Science is Happening Here publication refers to an "environmental studies section of The Formative Years" (Ontario Ministry of Education 1988, 3). After making several inquiries ${ }^{7}$ it was determined that the terms are meant to be interchangeable. In other words, the science is

7 The Ontario Ministry of Education, Ottawa University's Faculty of Education, and the Carleton Roman Catholic School Board were all contacted. 
Happening Here document is the curriculum guideline for both the science and geography components of the Primary and Junior programs: "environmental studies" or, as it is also called in Science is Happening Here, science and technology.

Smith $(1991,4)$ reite ates three statements that were made in Science is Happening Here with respect to involvement in the science and technology component of the educational program. According to Smith, the science and technology program will help children to:

- appreciate the beauty and value of their natural environment;

- respond constructively to changes effected through science and technology; and

- develop a positive attitude towards the conservation of natural resources (Smith 1991, 4).

There were originally eight points in science is Happening Here. Two other points that seem relevant to environmental education and are as follows:

- develop the attitudes, skills, and knowledge required to make informed decisions;

- enhance their self-concepts through their understanding of the environment (Ontario Ministry of Education $1988 \mathrm{a}, 6$ ).

According to the Science is Happening Here document the science learning environment should nurture the following attitudes:

- concern and care for the environment;

- respect for living things;

- consideration for others;

- open-mindedness;

- objectivity and accuracy;

- thoroughness and perseverance; 
- safety-mindedness;

- curiosity and risk taking (ontario Ministry of Education 1988, 17).

Smith lists only four of these attitudes as being relevant to environmental education. Each of the attitudes listed above is important in developing a well rounded individual who is environmentally aware.

Smith also goes on to list the learning opportunities from Science is Happening Here that he feels are relevant to environmental education in the Primary and Junior divisiors. This list includes: "demonstrate concern and care for the environment", "investigate human dependence on plants and animals", and "identify devices that may help corsserve energy". The entire list is included in spendix G. The list covers all the areas listed in science is Happening Here that deal, or could deal, with the environment. The way in which the individual teacher chooses to handle these learning opportunities will affect how relevant they are to environmental education. For example, one of the points in the Primary division states: "observe and describe a variety of living things." The teacher can approach this topic in at least two ways. First, students can observe and describe plants and animals, how they fit into the natural world, and their dependence on each other. Or, second, students can observe and describe plants and animals and discuss what we as humans take from them or make from them (eg. a baby seal becomes a fur coat). Again, it is left up to the teacher to 
choose to focus on environmental issues. Most of the learning objectives in Appendix $G$ can be achieved without raising environmental concerns / awareness.

\subsection{THE INTERMEDIA ${ }^{n}$ AND SENIOR DIVISIONS}

The general policy document governing the Intermediate and Senior Divisions is OS:IS (Ontario Ministry of Education 1989a). This document is very unlike The Formative Years in the Primary and Junior Divisions. It does not deal with specific learning opportunities, but instead, leaves that to the more specific curriculum guidelines. The os:Is document describes, in some detail, the programs and services offered to intermediate and senior students, as well as credits and ways to earn them (Ontario Ministry of Education 1989a).

Secondary education is designed to prepare adolescents to develop the independence they need to act as concerned and compassionate citizens and to continue their education if they have the interest and the capability to do so (Ontario Ministry of Education 1989a, 2).

At the Grade 7 and 8 (age 13 and 14 years) level many of the aims and objectives of the curriculum are identified in the individual course guidelines. There are, however, several objectives that are considered cross-curricular objectives and

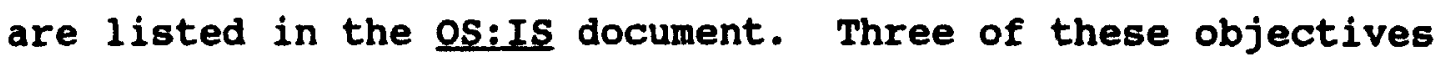


can play some part in the environmental education program. They are as follows:

- knowledge of Canada and Canadian society;

- awareness of the influences and rapid

developments of technology and communications; and

- appreciation of personal and societal values (Ontario Ministry of Education 1989a, 15).

There are no similar aims and objectives listed for the Grade 9 to OAC students (age 15 to 19 years), although the os:IS document does discuss the fact that in Grade 9 and 10 the program "is exploratory in nature. It should serve to help each student confirm interests, test talents, form clearer career goals, and begin to formulate more detailed plans for further study" (Ontario Ministry of Education 1989a, 16). At the Grade 11 and 12 level the document refers to the fact that students are able to pursue more specific career and life goals. They are able to "select a combination of courses that will provide them with the best foundation for personal career and life aspirations" (Ontario Ministry of Education $1989 a, 16)$.

From what is written in The Formative Years and os:Is it appears that the aims and objectives switch from being those of the Ministry to those of the student. Beginning in Grade 9 the program becomes student centred and is there to help students achieve their goals.

At the Intermediate and senior levels the curriculum guidelines are far more specific than at the Primary and 
Junior levels, to the point that there are fifteen volumes covering the Intermediate and Senior Division Science courses (Ontario Ministry of Education 1987b-h, 1988h-n, and 1989b). Smith (1991, 3) lists the courses the Ministry feels touch on environmental education. They are as follows:

\section{GEOGRAPHY}

Grade 7

PROBLEMS IN PHYSICAL GEOGRAPHY

Our Community is Unique

Environments in the News

River Systems

Fragile Environments

Grade 8

PATTERNS IN HUMAN GEOGRAPHY

Patterns in our community

Grade 9

GEOGRAPHY OF CANADA

Physical Diversity

Human Diversity

Natural Resources

Urban Canada

Grade 10

GEOGRAPHY OF EUROPE AND ASIA

The Land

The People

Comparisons

Change

Grade 11 ENVIRONMENTAL STUDIES

Grade 12

ENVIRONMENTAL STUDIES

OAC

WORLD ISSUES

OAC

CANADA: ITS ENVIRONMENT AND ECONOMY 
SCIENCE

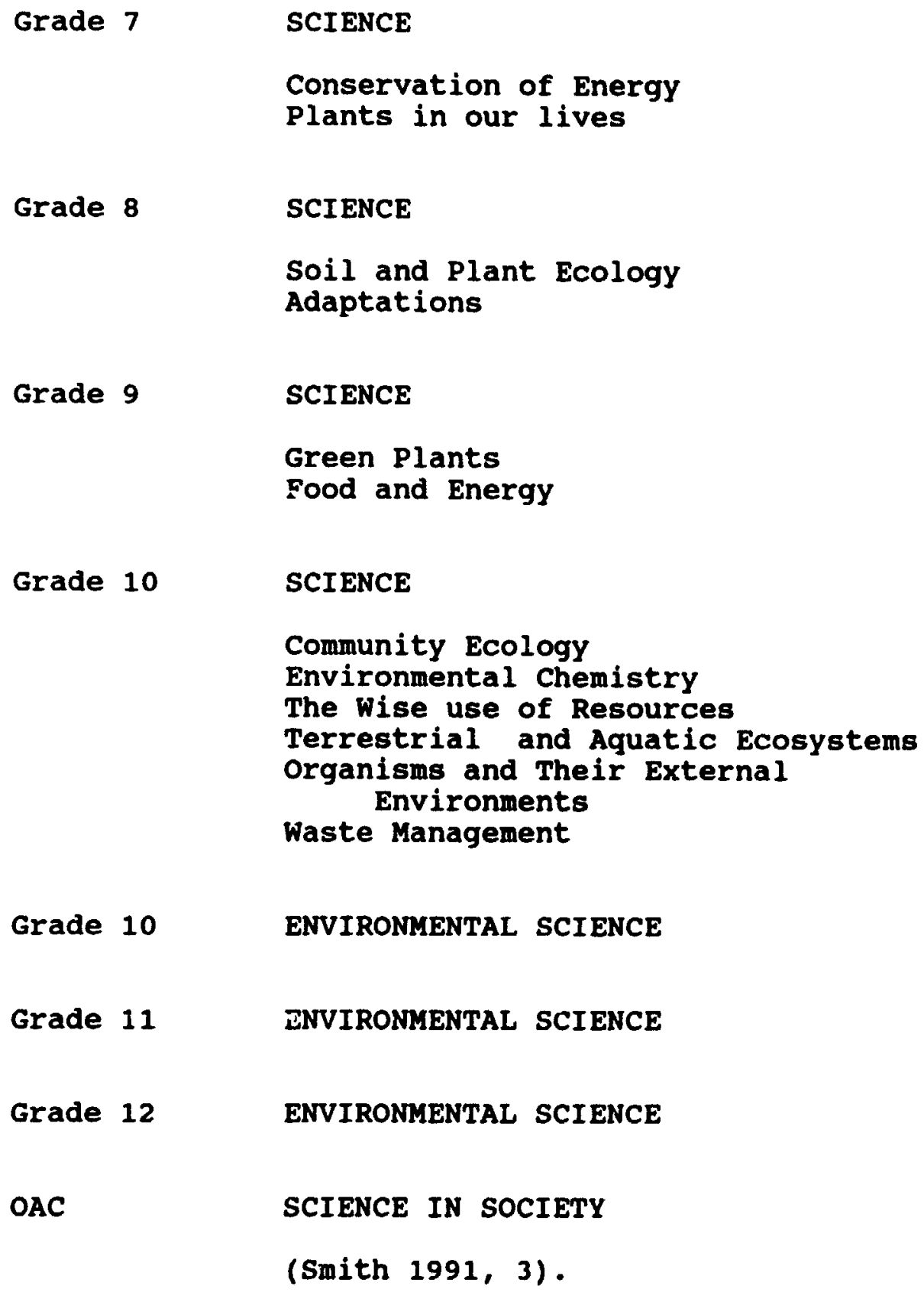

All the courses are from the Geography and science course offerings. In some cases a whole course is cited as being of an environmental nature (eg. Grade 12 Geography; 
"Environmental studies") and in other cases specific units are listed (eg. Grade 8 Science; "Soil and Plant Ecology").

Environmental education is not directly mentioned in many of the curriculum documents, but again, as in the case of the Primary and Junior Divisions, the individual teacher can choose to stress environmental issues. For example: the Grade 10 Geography course; "Geography of Europe and Asia", the unit titled "The Land" does not include specific mention of the environment, per se, but smith has included it in his list (Ontario Ministry of Education 1988d, 46).

New guidelines for environmental science were released in 1988 by the Ontario Ministry of Education. These guidelines gave teachers detailed curricula for courses in Grades 10 to 12. Previous curricular guidelines, issued in 1973, were so vague that only a minority of dedicated teachers had attempted to form a course from their contents (Cundiff 1989,16 ). As a result of these new guidelines 204 of 767 ontario secondary Schools offered their students one or more courses in environmental science in the fall of 1989 (Cundiff 1989, 16).

Bill Andrews, who teaches environmental science at University of Toronto's Faculty of Education, wrote a proposal for the revision of the course guidelines which was used as the basis for the current document. Andrews is quite critical of the lack of a solid link between the knowledge being developed and the attitudes that are supposed to flow from it. He feels that the new environmental science guideline is a 
"pretty good document" (Cundiff 1989, 17). It covers the environmental issues "alright", but what it's lacking is a cohesive ethical thread and it is up to the teachers to put that in. He states that: "nowhere does it say 'take action'" (Cundiff 1989,17 ). It is up to those teaching the course to see to it that students come away with "an ecosystem ethic... whatever you do aff'zcts something else" (Cundiff 1989, 17).

Only 268 of ontario's secondary schools offer a course in environmental science and "some school boards opt not to carry it at all" (Cundiff 1989, 17). Andrews believes part of the reason is that environmental science is "not considered a university - bound course". "It's not a prerequisite for any university program and, under the new guidelines, it cannot be taught at the OAC level" (Cundiff 1989, 17).

As far as the Ministry of Education is concerned, environmental science is an alternative for students who are not able to perform well in "the real sciences" (Cundiff 1989, 17). In defending the Ministry's approach Ms. Gerry Connelly, education officer for the Ministry of Educations's Centre for Secondary and Adult Education, has stated that: "Every major course has environmental awareness built into it." she referred particularly to geography and history. As well, she pointed out that schools can now offer a course called "Science and Society," at the OAC level, which dwells on such subjects as the nature of science and technology, humans in 
the environment and current issues in science (Connelly is quoted in Cundiff 1989,17$)$.

In the cundiff $(1989,17)$ article, Connelly was also quoted as saying: "We think environmental education is very important and we're working on it from a variety of directions, but we have to move into a more integrated kind of curriculum" (Cundiff 1989, 17).

Connelly and Smith need to start delivering the same message. Nowhere in the smith document does he refer to history courses or an "integrated kind of curriculum." From what is said by Smith one could infer the Ministry's intention to develop an integrated curriculum, but it is not stated as such.

According to cundiff, teachers in a variety of departments are trying to put forth an environmental message. "Environmental awareness is surfacing in courses ranging from family studies to history" (Cundiff 1989, 19). All too slowly environmental awareness is working its way into the Ministry guidelines.

In the 1989 throne speech, the Provincial Government committed itself to curriculum renewal for Grades 7 to 9. According to Connelly, "the major focus will be the environment" (Cundiff 1989, 19). In this case the Ministry is not fulfilling its role of "leadership and vision" (Ontario Ministry of Education 19880,6$)$, but is instead being pulled along by a grassroots movement that has overtaken it. 
The CRCSB has, in many ways, responded far more quickly to the outcry of environmental concern by its tax payers. The following chapter outlines the CRCSBs philosophy on environmental education and what action the Board has taken to date. 
CHAPTER FOUR

AN EVALUATION OF THE CARLETON ROMAN CATHOLIC SCHOOL BOARD'S ENVIRONMENTAL EDUCATION PROGRAM

\subsection{THE BOARD}

The Carleton Roman Catholic School Board (CRCSB) was formed in 1969 when a number of smaller county boards were amalgamated. The Board is located in eastern ontario. It covers much of the Regional Municipality of ottawa-Carleton. The Cities of Gloucester, Kanata, and Nepean, and the Townships of Cumberland, Goulbourn, Osgoode, Rideau, and West Carleton are all served by the Board (CRCSB 1991a) (Figure 4.1).

The Board operates a total of 40 schools, 34 elementary and 6 secondary, spread throughout the region. Figure 4.2 shows the location of each of the schools. Total enrolment was 20,090 students for the school year 1990-91 (CRCSB 1990a). There were 731 elementary teachers and 321 secondary teachers employed by the Board for that school year (Ontario Ministry of Education 1991, 114).

The schools of the CRCSB are grouped into "families". Each "family" has a high school and several elementary feeder schools in the same geographical area. Appendix $\mathrm{H}$ lists all Board schools by family unit (CRCSB 1991a). 


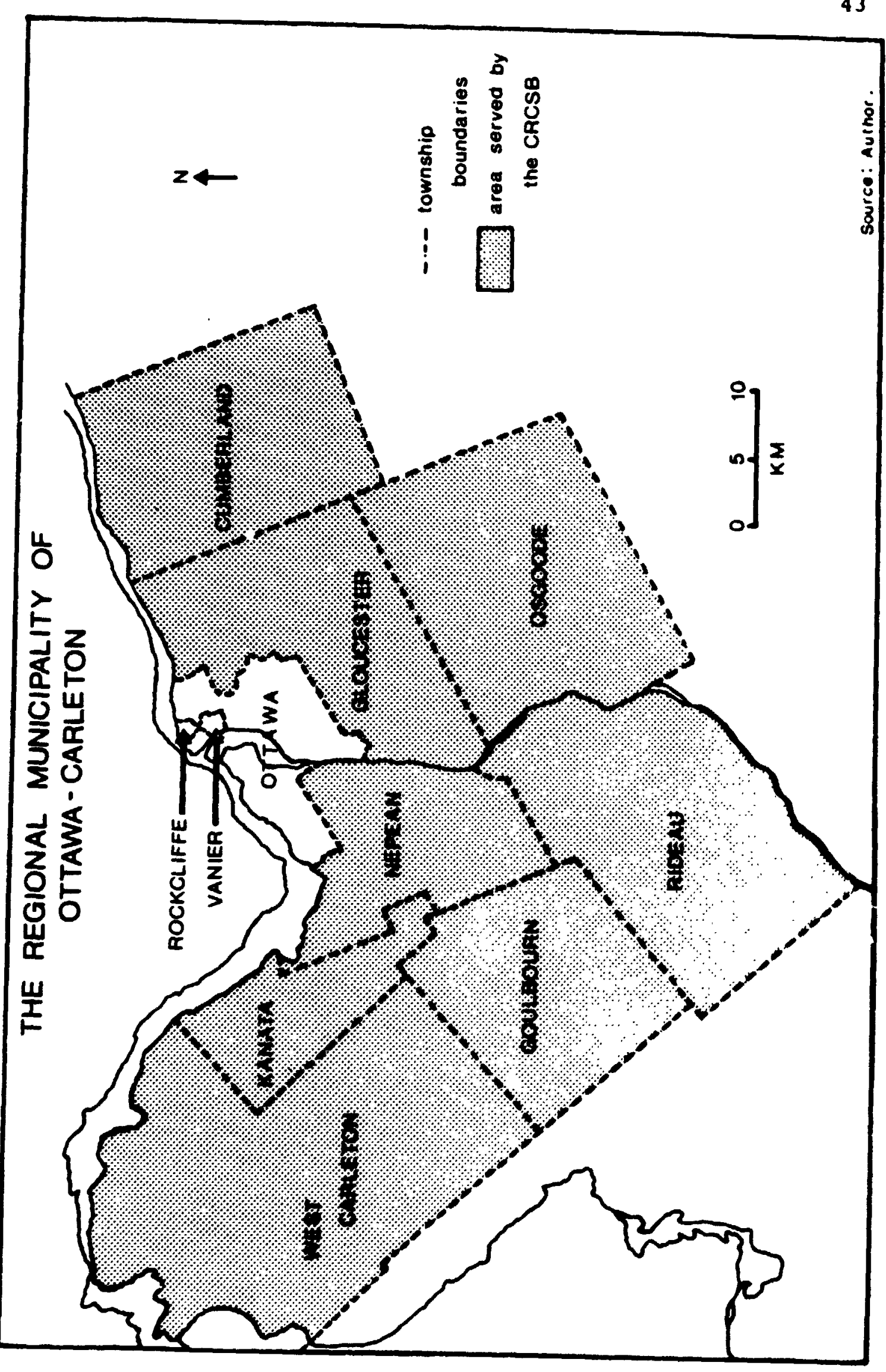




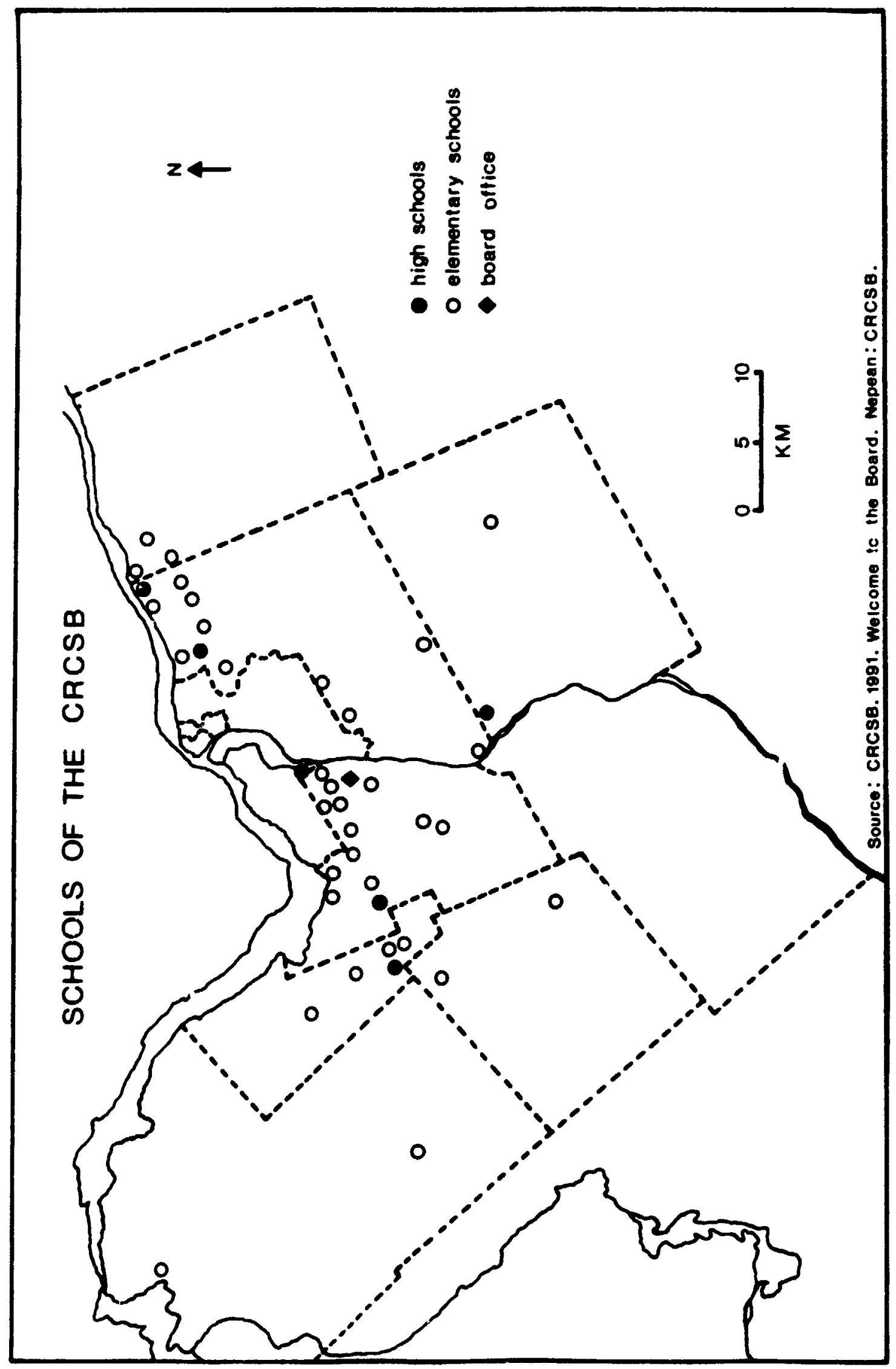


The CRCSB endeavours to provide "educational programs which develop the whole person, rhallenging each student to reach his or her full potential spiritually, intellectually, physically, socially, and emotionally" (CRCSB 1991b).

The Carleton Roman Catholic School Board views learning as a life-long experience and is dedicated to providing educational opportunities for all students to develop knowledge, skills and values which will enable them to become productive, responsible, Catholic members of an increasingly complex and changing society (CRCSB 1991b).

The Board aims rol achieve this mandate through five goals, each goal containing between five and eight s'dbsections. The goals can be found in their entirety in Appendix I. The section of the goals which is of importance to this paper is a subsection of Goal 2 and states that:

The Board believes that all students [should] be provided with opportunities to: ...develop an awareness, knowledge, responsibility and appreciation of the environment (CRCSB 1991b).

This is the only time the environment is mentioned in the Board's goals. Also, no reference is made to environmental issues in the Board's mandate. This, however, seems in keeping with the Ministry of Education's goals. As stated previously, the Ministry only mentioned environmental education in one of thirteen goals (Ontario Ministry of Education $1989, ?$ ).

Ir. an attempt to meet its environmental goal the Board has established an environment committee. Generally, the role of the committee is to encourage environmental awareness in both its staff and students. 
4.2 THE ENVIRONMENT COMMTTEE

In October of 1989 the CRCSB voted to examine the need to establish an Environmental Action Ad Hoc Committee (Environment Committee) (CRCSB 1989, 13). The Board suggested that the committee would have representation from the following groups: "trustees, administration, teachers, PTA [Parent - Teacher Association], PCC [Parent Communications Committee] and students" (CRCSB 1989, 13). The committee was to establish the terms of reference and take them back to the Board for approval. Trustees Armstrong, Brasset, Kelly, MacPhee and Stankovic were all appointed to the committee.

The first meeting of the Environment Commitiee was held on November 21st, 1989 (CRCSB 1989b,2). At this meeting the committee established its mandate and terms of reference. The mandate of the Environment Committee is as follows:

1. To develop a CRCSB mission statement concerning environmental issues.

2. To review the curriculum invoiving environmental issues and to make recommendations concerning content, resources, and facilities in the elementary and high school.

3. To identify and promote environmental

initiatives which can be readily implemented. (CRCSB 1989b, 2).1

The Environment Committee developed a policy statement regarding environmental action. The policy statement was

1 As adopted by the Board on the 19th of December 1989 (CRCSB 1989C, 8). 
adopted by the Board on the 5th of March 1991 and reads as foll.ows :

1. Environmental issues, concerns and solutions should be integrated into the curriculum of a variety of subjects in all grade levels.

2. Instruction in environmental education should be realistic, age appropriate, respect the principles of student development and be oriented to positive and attainable action.

3. A program of education for teachers and pupils which reflects the environmental concerns of this Board and the community as a whole should be encouraged.

4. The Bcard shall consider environmental issues and concerns in developing its purchasing, building, educational and maintenance programs (CRCSB 1991C).

The committee meets once a month throughout the school year. Anyone wishing to promote environmental awareness or who has useful environmentally oriented suggestions for the Board is welcome to make a presentation to the committee. As well, the Board refers any environmental matters to the committee for consideration. Committee initiatives have included starting a Board-wide recycling program and coordinating the Board's professional development day on environmental education.

Environmental issues have become such a concern that, at a meeting of the Board on the 3rd of March 1992, Trustee Armstrong brought forward a motion to change the Environment Action Ad HoC Committee to a permanent standing committee. The Board voted in favour of this motion. The name of the committee was thus changed to the Environmental Action 
Committee to reflect its new status as a permanent standing committee of the Board (CRCSB 1992, 11).

It should be noted here that there was and still is no Ministry requirement for the Board to have such a committee. 2 The committee was initially created out of the concern individual Board members had for tine environment. The Board members felt that they needed to emphasise environmental issues to heighten awareness and promote environmentally responsible activities within the schools. Once the committee was established and the hard work of its members began to make a difference to the environmental outlook of the Board, it was made a permanent standing committee.

\subsection{THE ENVIRONMENTAL EDUCATION PROGRAM}

The CRCSB believes that environmental education is "an attitudinal and life style change" (CRCSB 1990b, 2). The Board strives to heighten the awareness of its educators "of not only the issues, but also of curricular activities and resources" leading to "a more thorough integration of environmental education in all schools" (CRCSB 1990b,2). In attempting to meet this aim, the Board has created a document, Ecology and Applied Ecological Themes in the K-OAC Curriculum (CRCSB 1990b), which describes its stand on environmental

2 The other school boards in the ottawa area were contacted and none of them reported having a similar mechanism for dealing with environmental issues. 
issues and identifies where these issues are taught in the curriculum.

The list of current environmental issues that the CRCSB has compiled is as follows:

CAUSATIVE AGENTS OF THE ENVIRONMENTAL CRISIS

Over-population Resource Depletion

ENVIRONMENTAL DEGRADATION

Atmospheric

Ozone Depletion Greenhouse Effect Acid Rain

Smog and airborne pollutants

Aquatic

Water Quality

Toxic Waste

Terrestrial

Garbage Volume-Packaging Landfill limitations and the 4 Rs Deforestation Desertification

Biotic Species Extinction and Habitat Depletion (CRCSB 1990b, 1).

The Board feels that these issues are addressed adequately throughout the Primary - Junior Environmental studies program and the Intermediate - Senior Science, Geography, and Family studies programs. These issues are similar to the issues the Ministry of Education has listed as environmental issues (Patrick, May 1991). Where the list varies is that the Ministry includes a section on biotechnology that is not included by the Board. 
Appendix $J$ describes the environmental units and topics discussed at each level. Each of the environmental issues listed above is addressed in this curriculum before the end of Grade 10 (CRCSB 1990b, 1). Because the Board has adopted a spiral curriculum approach many of the issues are addressed several times at different grade levels, thus facilitating an "adequate understanding of the issues" (CRCSB 1990b, 2).

When this list is compared to the list established by the Ministry of Education some differences appear. The Board has put far more thought, than the Ministry, into where environmental issues can be included (eg. family studies) and has offered worthwhile suggestions on the environmental topics to be covered in each unit. 3

At the Primary and Junior levels specific environmentally geared units have been developed or purchased by the Board for use in its classrooms. For example: Grade 4 has four units listed: "All Charged Up", "Beetling Along", "Blooming Blocks", and "Tuning In". These units focus on sources and uses of energy, insects, plants, and noise pollution respectively. Each child in Grade 4 will take all four of these units.

At the Intermediate and senior levels courses are listed with specific units and topics being described for each course. For example: the Grade $11 / 12$ geography course,

3 The Board's list of environmental units and topics was compiled by the Board's science consultant at the request of the Environment committee. 
"Human Geography", contains four units that touch on the environment: "An Overview of Human Geography", "Population and Environment", "Global Village", and "Changes, Trends, Planning" Topics/concepts are also described for each unit. The first unit, "An Overview of Human Geography", delves into "human uses and abuses of the natural environment."

According to members of the Environment Committee the Board and the schools themselves are trying to develop and foster a "global" environmental education program. They are trying to make environmental awareness a way of life within the schools, from $K$ - OAC. Members of the Environment Committee feel that it is not enough to introduce environmental concepts and issues into the curriculum. The students and the schools must adopt environmentally friendly habits in everything they do. The Board is trying to influence both the cognitive and affective domains of the child. It is not enough to teach a child about overflowing landfills, the child also has to be shown what to do about it: eg. reduce, reuse, recycle.

\subsection{RESULTS OF THE BOARD'S ENVIRONMENTAL QUESTIONNAIRE}

On March 25th 1991 (CRCSB 1991d), in an attempt to find out more about the environmental education program in each of its schools, the Environment Committee approved the design and 
distribution of a questionnaire. ${ }^{4}$ one questionnaire was distributed to each school to be answered by the environmental representative in the school. Appendix $\mathrm{K}$ contains a copy of this questionnaire. Since the questionnaire addresses issues that are of interest to this paper its findings will be briefly discussed.

Nembers of the Environment Committee were satisfied with the responses they received even though some of the schools were not aware that the Board had established an environmental committee: only 80 of the elementary schools were aware of the committee, while all of the secondary schools knew of its existence.

The Environment Committee asked the respondents for suggestions as to what it, the committee, could do to help facilitate environmental education in the schools. Aside from the common suggestions of more participation and better communication, a suggestion was made that the Board sponsor a conference for students. Students from different schools could then get together and compare programs and ideas.

The respondents were asked whether there was an environment club in their school. Eight of the 34 eleme tary schools and all of the secondary schools have environmental clubs, with memberships ranging from 3 to 50 .

4 To clarify, this questionnaire was not designed for this research project. It was developed by the Environment Committee and they graciously agreed to aliow use of their results in this work. 
All schools in the system run recycling projects. All schools recycle tin cans and newsprint, and most recycle bottles and fine paper. Facilities are not available in all areas for fine paper recycling. Very few glass bottles are used in the schools, which makes recycling projects for glass rather costly. Fewer than half the schools promote litterless lunches. One respondent suggested that "litterless living" should be promoted instead.

Questions were posed regarding environment projects and topics in the school curriculum, and outdoor environmental education. From the responses to these questions a list of topics was compiled which included some of the units described in Appendix $J$, Environmental Education at the CRCSB. For example: Mother Nature's Recipes at the Grade 3 level. Some of those units and activities not covered in Appendix $J$ are: adopt a whale, tree planting, school garciens, composting, environmental camping trips, visits to conservation areas and landfill sites.

The vast majority of the schools, roughly 908, participated in Earth Day 1991. Special activities ranged from guest speakers and lectures to community cleanups and tree planting. Unfortunately, the questionnaire does not give the participation level within each of the schools. 
The respondents indicated that there was a need for teacher education in the area of environmental issues. 5 A Board-wide professional development day was dedicated to environmental education, 15 February 1991, and yet the questionnaire respondents seemed to feel far more education was necessary. Several respondents suggested that suitable environmental education materials be made more readily available to teachers. As well, more information on current environmental issues needs to be made available. Teachers simply have too much to do to be spending time hunting through books and magazines to learn about the environment. If this information was readily available, it would be far easier to incorporate it into the individuai classroom curriculum. Suggestions were also made regarding inservice training, conferences and more professional development days on the subject of environmental education and outdoor education. Environmental education is still relatively new to the Board, the Environment Committee having been formed in 1989. It will take some time for the Board to develop and implement the projects it has "in the works". Several committee members said that they felt the Board was "on the right track" and that it would just be a matter of time before environmental education would become an integrated part of daily life within the Board.

5 This question is missing from the copy of the questionnaire that was submitted to the Board on the 25 th of March 1991. 
Chapter 5, the following chapter, explores the Boards activities further. The chapter is an analysis of the data collected during interviews with persons involved with the Board. 
CHAPTER FIVE

DATA ACQUISITION AND ANALYSIS

\subsection{DATA ACQUISITION}

In the spring of 1991 persons involved with the CRCSB were interviewed. Appendix A contains a copy of the questions that were asked during the interviews, referred to as the interview guide. In total 35 face to face interviews were conducted. Persons interviewed had a wide range of responsibilities at the Board, from the Chairman of the Board to the students (Table 5.1). Interviews ranged in length from thirty minutes to four hours. All interviews were conducted by this researcher in the months of April and May 1991. Contacts were also made with persons from other school boards, Ottawa University and the Ministry of Education at various times. A complete list of persons contacted in relation to this paper is attached after the Bibliography.

All interviews with persons from the CRCSB were arranged with the help of Mr. Vic D'Amico, Superintendent of Secondary Programs. Mr. D'Amico made the initial contact with all the participants. He stated that he was contacting persons on my behalf and asked if they would be willing to participate in this study. Mr. D'Amico was asked to contact a range of people with various positions and involvements. He was asked to choose people at random without asking whether they were involved with the environmental education program. 
TABLE 5.1: PARTICIPANT INVOLVEMENT

\begin{tabular}{|l|c|c|}
\hline \multicolumn{1}{|c|}{ INVOLVEMENT } & NO. & \\
\hline environment committee members & 4 & 31.4 \\
\hline trustees & 3 & 8.6 \\
\hline superintendents & 1 & 2.9 \\
\hline consultants & 2 & 5.7 \\
\hline administration staff & 2 & 5.7 \\
\hline parents & 1 & 2.9 \\
\hline elementary school principals & 1 & 2.9 \\
\hline secondary school principals & 1 & 2.9 \\
\hline secondary school vice-principals & 1 & 2.9 \\
\hline elementary school teachers & 9 & 25.7 \\
\hline high school teachers & 7 & 20.0 \\
\hline students & 7 & 20.0 \\
\hline
\end{tabular}

NOTE: It should be noted here that all the participants listed under environment committee are also listed under their normal designation/job within the Board. For example the parent interviewed was also a member of the environment committee therefore he appears under both the environment committee designation and parent designation. The environment committee category was kept separate and not acided into the total sample figures to avoid duplication of their opinions. 


\subsection{RESERिRCH DESIGN}

The interviews were designed to collect both qualitative and quantitative data. With respect to quantitative data the emphasis was placed on descriptive statistics as opposed to inferential statistics due to the small sample size. A far larger group of people would have had to have been interviewed in order to employ inferential statistics.

Part $A$ of the interview guide queried the participants about themselves. Four demographic questions were asked: name, position, educational. background and number of years with the Board. The participants were then asked for their views on the environment and for a brief description of any environmental activities they had participated in. The second part of the guide dealt with the program at the CRCSB. These questions were designed to probe the interviewee's knowledge of the Board's program ${ }^{1}$, where they saw environmental education heading in the next fer years and if they felt anything was lacking from the current program.

\subsection{THE DATA}

The first key question asked was the number of years the individual had been involved with the Board (question A4).

1 As stated earlier, all comments made are the participants own beliefs and may not reflect Board policy and practice. 
Answers ranged from 1 to 23 years. Figure 5.1 shows the distribution. Note that the majority have been with the Board less than 8 years. The average number of years with the Board was 8.9 for the total sample. The teachers interviewed have been with the Board the longest with an average of 10.3 years. The students had an average of 9.1 years and the Environment Committee members were the least experienced, having only been active in the Board for an average of 5.8 years.

The participants were then asked to rank themselves, with regard to their environmental awareness (question A5). of the 35 respondents 28 , or 808 , indicated that they felt they were well informed or informed about environmental issues. One person placed themselves in the not very environmentally aware category and nobody in the sample said that they were not at all informed (Figure 5.2).

From talking to the participants it soon became evident that the term "environmentally aware" meant something different to each of them. One participant felt that because she lived in the country she was environmentally aware while the person that put himself in the not very environmentally aware category was one of the most environmentally knowledgable of the persons interviewed. This person felt that even though they knew a great deal about environmental issues and they were making a concerted effort to be an environmentally conscious individual and act responsibly in their daily lives there was still a great deal to learn and 
$\frac{\dot{\omega}}{\frac{\pi}{\sigma}}$

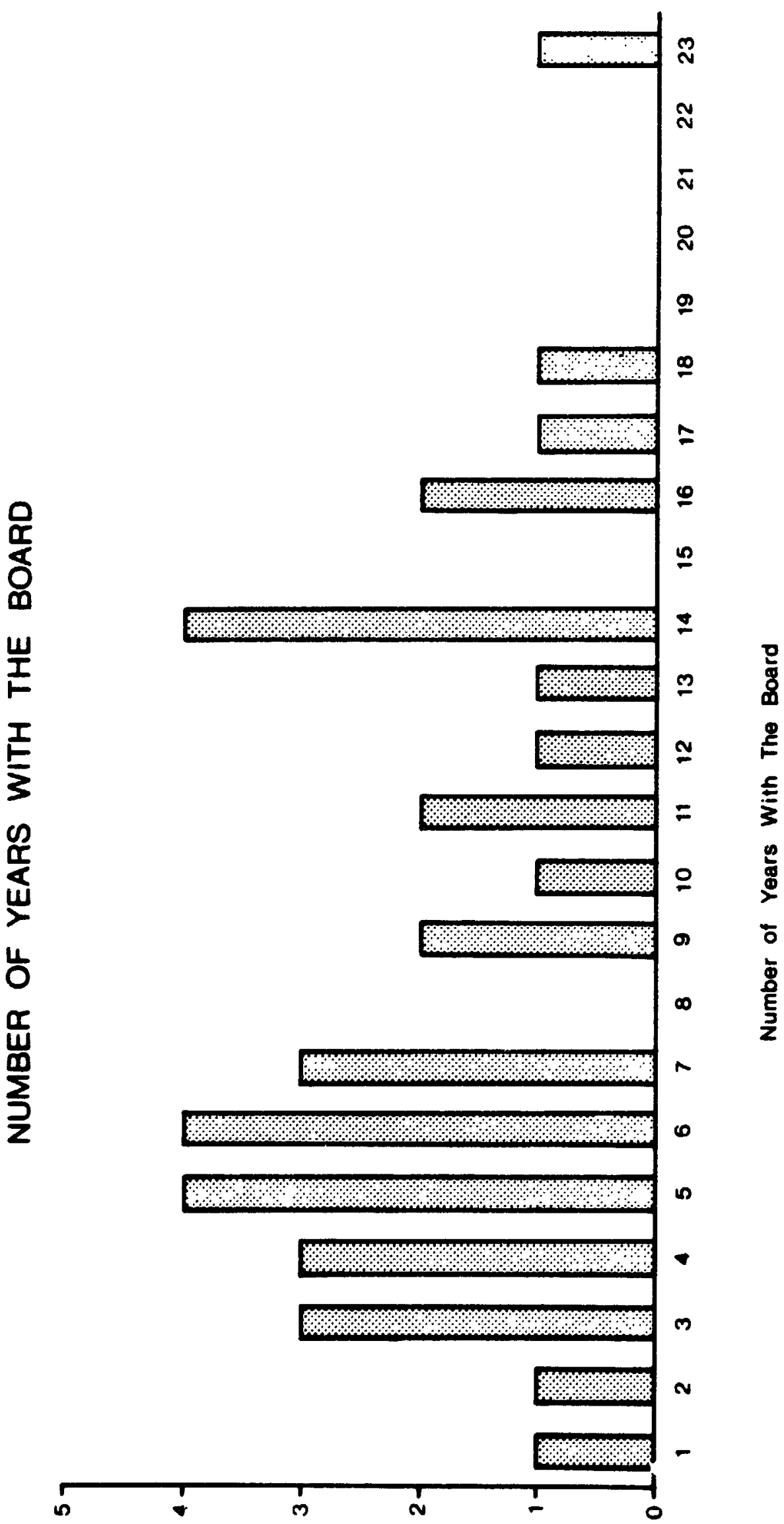


FIGURE 5.2

\section{DO YOU CONSIDER YOURSELF ENVIRONMENTALLY AWARE?}

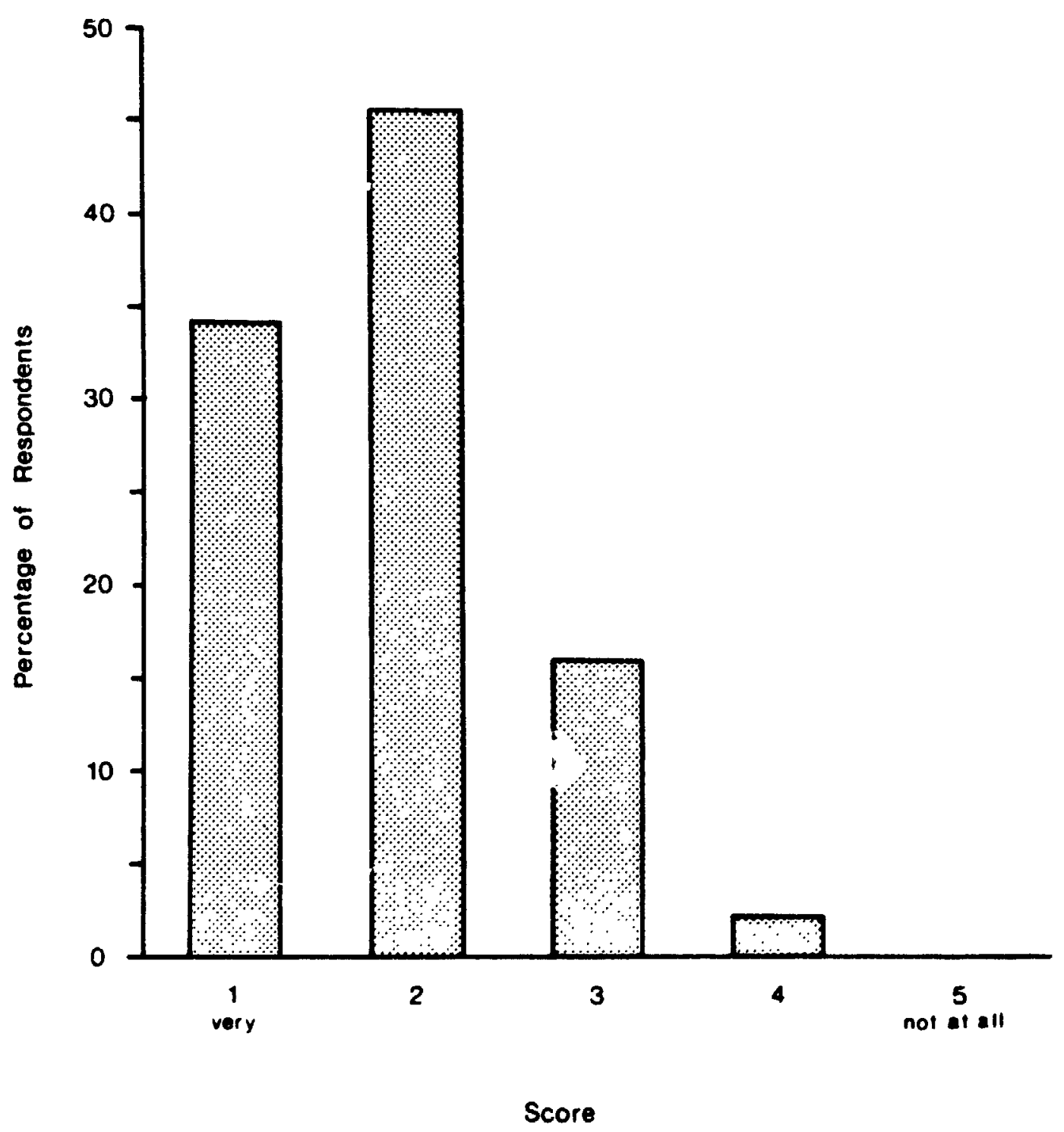


do. The researcher is, thus, sceptical as to the validity of this question. People tend to put themselves in the best possible light and that fact has been reflected in the responses elicited in this case.

Because so much of what goes on in schools is modeled by the students, it was felt that some information needed to be collected on participants' practices while conducting Board related activities (question A6). The participants were asked to rank themselves on a variety of "environmentally friendly" behaviours. As Table 5.2 illustrates, the respondents saw themselves as acting in an environmentally friendly manner always or almost always. For 6 of 7 of the behaviours addressed the participation rate was over $70 \%$. The bringing of garbage free lunchrs was the behaviour that was practised the least. Only $28.6 \%$ of the respondents always brought garbage free lunches and 31.48 almost always for a total of 608.

The respondents seemed quite sincere in their attempts to be environmentally friendly. One of the teachers interviewed who did not have access to recycling facilities for glass at school went so far as to collect these containers and take them home to put in his own blue box. 
TABLE 5.2: ENVIRONMENTALLY FRIENDLY BEHAVIOURS

\begin{tabular}{|c|c|c|c|c|c|c|}
\hline \multirow[t]{3}{*}{ BEHAVIOUR } & \multicolumn{6}{|c|}{$\begin{array}{c}\text { SCORE } \\
\text { if and (no.) }\end{array}$} \\
\hline & \multicolumn{4}{|l|}{ Always } & \multicolumn{2}{|c|}{ Never } \\
\hline & 1 & 2 & 3 & 4 & 5 & N/A \\
\hline $\begin{array}{l}\text { paper } \\
\text { conservation }\end{array}$ & $\begin{array}{l}54.3 \\
(19) \\
\end{array}$ & $\begin{array}{l}34.3 \\
(12) \\
\end{array}$ & $\begin{array}{r}11.4 \\
(4) \\
\end{array}$ & 0 & 0 & 0 \\
\hline $\begin{array}{l}\text { energy } \\
\text { conservation }\end{array}$ & $\begin{array}{l}40.0 \\
(14) \\
\end{array}$ & $\begin{array}{l}34.3 \\
(12) \\
\end{array}$ & $\begin{array}{c}17.1 \\
(6) \\
\end{array}$ & $\begin{array}{l}5.7 \\
(2) \\
\end{array}$ & 0 & $\begin{array}{l}2.9 \\
(1) \\
\end{array}$ \\
\hline $\begin{array}{l}\text { recycling of } \\
\text { paper }\end{array}$ & $\begin{array}{l}68.6 \\
(24) \\
\end{array}$ & $\begin{array}{c}25.7 \\
(9) \\
\end{array}$ & 0 & $\begin{array}{l}2.9 \\
(1) \\
\end{array}$ & $\begin{array}{l}2.9 \\
(1) \\
\end{array}$ & 0 \\
\hline $\begin{array}{l}\text { recycling of } \\
\text { glass }\end{array}$ & $\begin{array}{l}51.4 \\
(18) \\
\end{array}$ & $\begin{array}{c}20.0 \\
(7) \\
\end{array}$ & $\begin{array}{l}2.9 \\
(1) \\
\end{array}$ & 0 & $\begin{array}{l}5.7 \\
(2) \\
\end{array}$ & $\begin{array}{c}20.0 \\
(7) \\
\end{array}$ \\
\hline $\begin{array}{l}\text { recycling of } \\
\text { tins }\end{array}$ & $\begin{array}{l}65.7 \\
(23) \\
\end{array}$ & $\begin{array}{c}14.3 \\
(5) \\
\end{array}$ & $\begin{array}{l}2.9 \\
(1) \\
\end{array}$ & 0 & $\begin{array}{l}2.9 \\
(1) \\
\end{array}$ & $\begin{array}{c}14.3 \\
(5) \\
\end{array}$ \\
\hline $\begin{array}{l}\text { garbage free } \\
\text { lunches }\end{array}$ & $\begin{array}{l}28.6 \\
(10) \\
\end{array}$ & $\begin{array}{l}31.4 \\
(11) \\
\end{array}$ & $\begin{array}{l}34.3 \\
(12) \\
\end{array}$ & 0 & 0 & $\begin{array}{l}5.7 \\
(2) \\
\end{array}$ \\
\hline $\begin{array}{l}\text { reusable } \\
\text { containers }\end{array}$ & $\begin{array}{l}34.3 \\
(12)\end{array}$ & $\begin{array}{l}48.6 \\
(17)\end{array}$ & $\begin{array}{c}11.4 \\
(4)\end{array}$ & $\begin{array}{l}2.9 \\
(1) \\
\end{array}$ & $\begin{array}{l}2.9 \\
(1)\end{array}$ & 0 \\
\hline
\end{tabular}

NOTE: Participants, when answering the recycling of glass and tins questions, put themselves in the not applicable (N/A) category because they did not use glass or tins when conducting Board related activities. The two respondents who put themselves in the $N / A$ category for garbage free lunches went home for lunch, in one case, or did not eat lunch in the other case. The person who, under energy conservation, put themselves in the $N / A$ category felt that the use of energy was beyond their control while conducting Board related activities.

As part of question A6, the participants were also asked to rank themselves with respect to environmentally friendly transport. Unfortunately the question divided environmentally friendly transport into subgroups i.e. bus, walking, and small car. This subdivision proved confusing and has made the data 
unusable. The researcher can not comment on a certain percentage of participants using environmentally friendly transport because some participants indicated that they bused or walked all the time and therefore put themselves in category 1 for two different modes of transport. The question should have simply been "do you use environmentally friendly transport", with the modes of transport as examples and not subcategories.

Questions were asked concerning when participants first became aware of the need for environmental awareness education (question $\mathrm{A7a}$ ) and when they first began incorporating environmental education concepts in their activities (question $A 7 b)$. Answers to the first question ranged from 2 to 23 years ago, with 14.38 of the respondents saying "always". Approximately a third $(31.4 \%)$ of the respondents said they began incorporating environmental education concepts in their activities shortly after becoming aware of the need for environmental education, 14.38 of the respondents said "when they first began teaching" and 22.98 responded "always". What is interesting to note here is that all the respondents indicated that they had "become aware of the need for environmental awareness education" sometime in the past and that all of them had begun "to encourage/include environmental education concepts in [their] activities".

Question B5 asked participants to comment on their "current involvement in the environmental awareness education 
program". Only 5.78 indicated that they had no involvement with the program. Of those that indicated an involvement with the program 9.18 said that their involvement was due to job requirements. Respondents indicated that they were involved in a variety of activities such as: sitting on an environment committee (either school or Board) (24.2\%), teaching (15.28), actively recycling (33.38), or participating in school clubs $(9.18)$.

Just over fifty percent (57.18) of the respondents had attended environmental awareness workshops (question A8). Respondents indicated attending from 1 to 20 in the last five years (the majority attended 5 or less). A variety of topics were covered by these workshops, everything from practical "awareness" sessions to global issues. One quarter (25.7\%) of the participants reported attending the Board's professional development day, held in February of 1991, that dealt with the environment.

At least half of the respondents indicated that they were willing to attend any worthwhile workshop or information session on the environment. Those that nad attended a large number of these events indicated that they became somewhat repetitious after a while. They said that they were hearing the same things over and over again. There seemed to be few new ideas in recent years.

Participants were asked if they felt teachers were well informed on environmental issues (question B9a). Roughly 
half, 48.6\%, responded "yes" and 378 "no", 8.68 said "some" and 5.78 said they "didn't know." The follow up question here was if the teachers are not well informed "how can they be better informed" (question B9b). Table 5.3 summarizes the participants' responses to this question. "Professional development day activities" at 48.68 was, by far, the most popular suggestion.

TABLE 5.3: HOW CAN TEACHERS BECOME BETTER INFORMED ON ENVIRONMENTAL ISSUES

\begin{tabular}{|l|c|c|}
\hline \multicolumn{1}{|c|}{ METHOD } & NO. & \& \\
\hline literature & 9 & 25.7 \\
\hline audio visual aids & 8 & 22.9 \\
\hline compulsory workshops & 8 & 22.9 \\
\hline voluntary workshops & 10 & 28.6 \\
\hline professional development day activities & 17 & 48.6 \\
\hline other 2 & 7 & 20.0 \\
\hline
\end{tabular}

The respondents indicated that no one group was responsible for educating teachers on environmental issues. The respondents felt that it should be a collaborative effort between the Ministry, the Board, the administration and the

2 Suggestions respondents had under "other" were: students, the Environment Committee and personal professional development. 
teachers. The feeling here was that the teachers needed help. They could not be expected to go out and learn about the environment on their own. Teachers already commit a large amount of their time to teaching. They take summer courses, attend workshops and spend evenings marking and creating lesson plans. Teachers need some help and encouragement if they are going to be expected to include environmental concepts in their classrooms.

The majority of the interviewees, 68.68 , felt that the movement to include environmental concepts in the education program began in the classrooms (40\%) and the schools (28.68) (question B1). Only $8.6 \%$ of the respondents felt that the movement began at the Board staff and administration level and only 5.7\% at the Ministry level. Participant perception is quite correct. As discussed previously, the Ministry is only now beginning to discuss environmental education. The smith document, written in 1991, is a first tentative step towards articulating a firm environmental policy. The school Board is not that far ahead. They established the Environmental Action Ad Hoc Committee in November of 1983 and began to examine environmental education seriously at that time. Information collected during the interviews indicates that employees of the Board, both teachers and administrative staff, had been working to include environmental issues in the classroom long before either the Board or Ministry made any attempt to do so. 
This notwithstanding, 88.62 of the respondents indicated that the Board is now taking more responsibility for environmental education than it had in the past (question B2). Respondents cited activities such as the recycling program (54.38), the creation of the Environment Committee (208) and the Board's attempts to try and include environmental concepts in every course (20\%). Again, these perceptions are correct. Since 1989 the Board has taken an active interest in incorporating environmental awareness in everything it does. It has even discontinued the use of weed killer in its school yards and examined the possibility of creating a compost pile at every school.

As discussed in the previous chapter, the CRCSB is attempting to make environmental awareness a way of life in its schools. The Board wishes to see environmental concepts taught throughout the curriculum and introduced where appropriate in school activities. This goal has been reflected in the responses received during this research project. Almost three-quarters $(71.4 \%)$ of the respondents agree with the Board's vision. They see environmental awareness being taught "throughout the curriculum, as a way of life" (question B4).

In order to instill this "way of life" in students environmental awareness must begin early. The vast majority, 88.68, of the participants felt that environmental awareness concepts should be introduced as early as possible or as early 
as understanding would allow (question B3). Participants indicated that in order for good environmental behaviour to become part of their daily lives, students have to be exposed to these habits early in life, when they are most impressionable.

Questions were asked about the Board's environmental awareness education program today (1991) and 5 years ago (1986) (questions $B 6$ and B7). On the 5 point scale 42.98 said the program was average today, while the program 5 years ago was rated as poor by 45.78 of the respondents. Respondents definitely feel that there has been an improvement in the last 5 years. When rating the program 5 years ago none of the respondents felt that the program rated good or excellent, but 34.38 of the respondents rated the program as good or excellent today. Figure 5.3, on the following page, shows the distributions for both periods. This perceived improvement in the program is most likely due to the fact that the Board, as discussed previously, has taker a more active role in environmental education in the past few years.

When separating out the teacher and student groups the frequency charts look somewhat difterent. The teachers, as a group, seem to be more cohesive in their opinion with respect to the Board's program than the students. Figures 5.4 and 5.5 illustrate the difference in opinion between the two groups. 


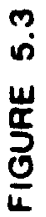

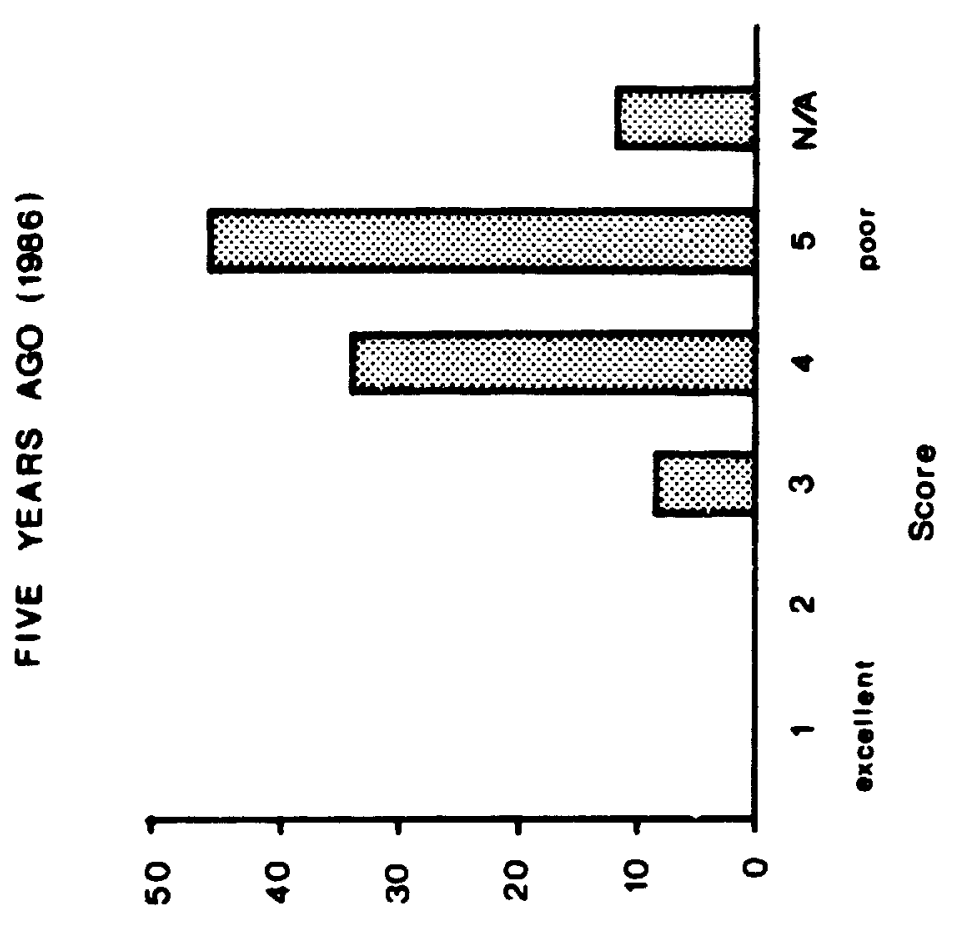

$\underline{\underline{F}}$

殅

Percentage of Respondents

$\frac{0}{\frac{2}{2}}$

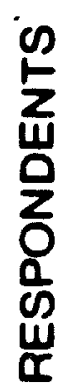

恋

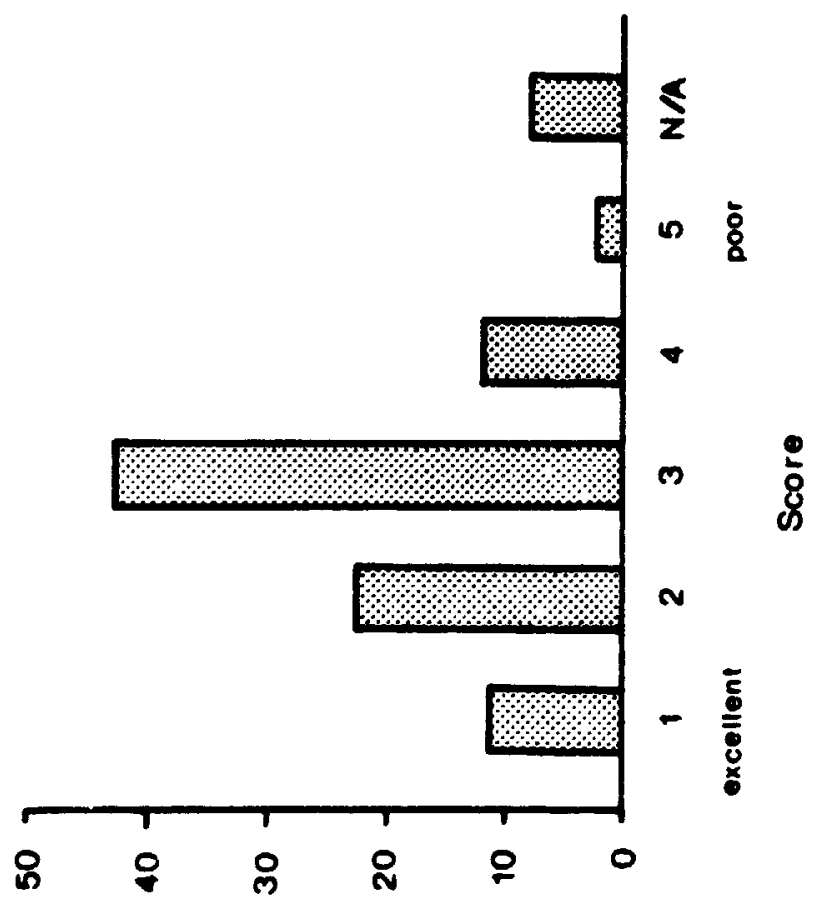

Percentage of Respondents 
in
ư
$\frac{0}{5}$
$\frac{0}{4}$
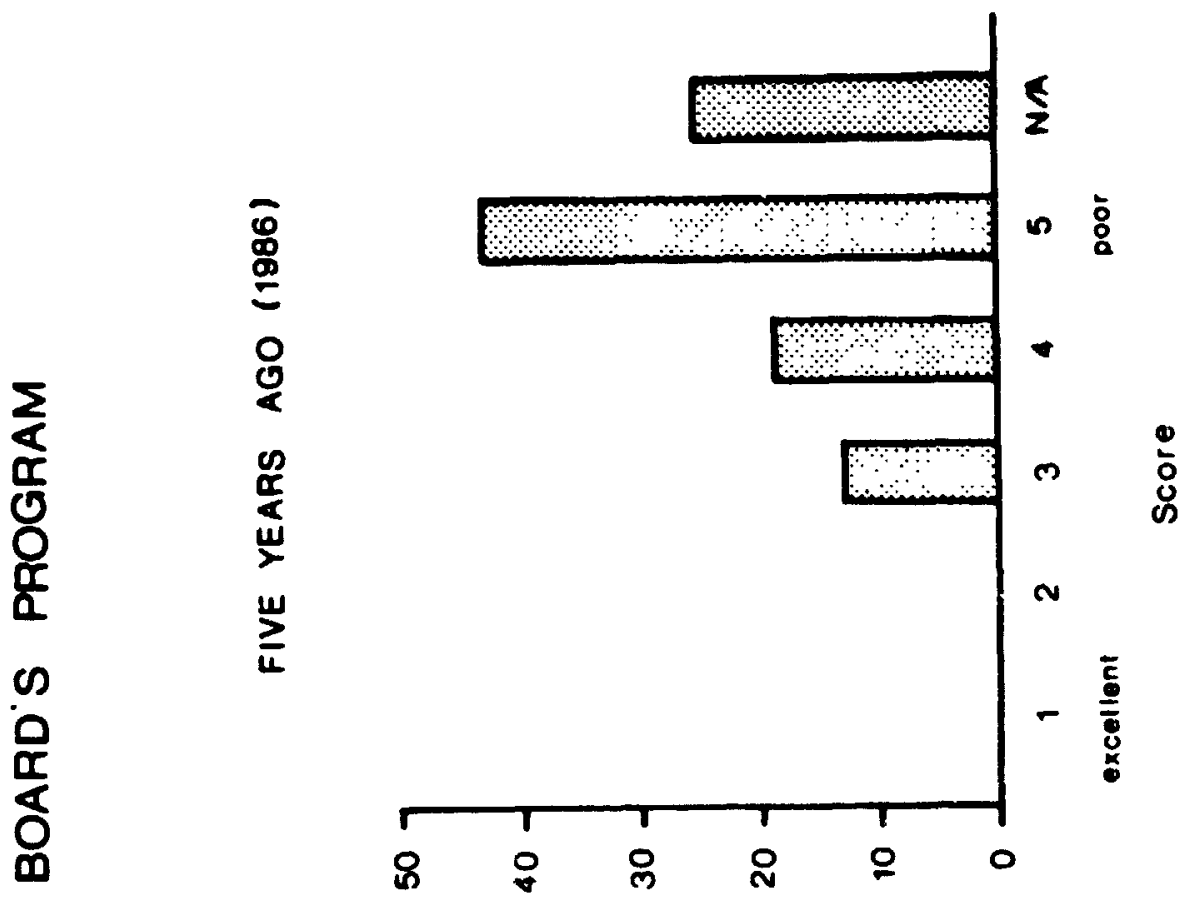

I

Percentage of Respondents.

แั

$\frac{5}{2}$

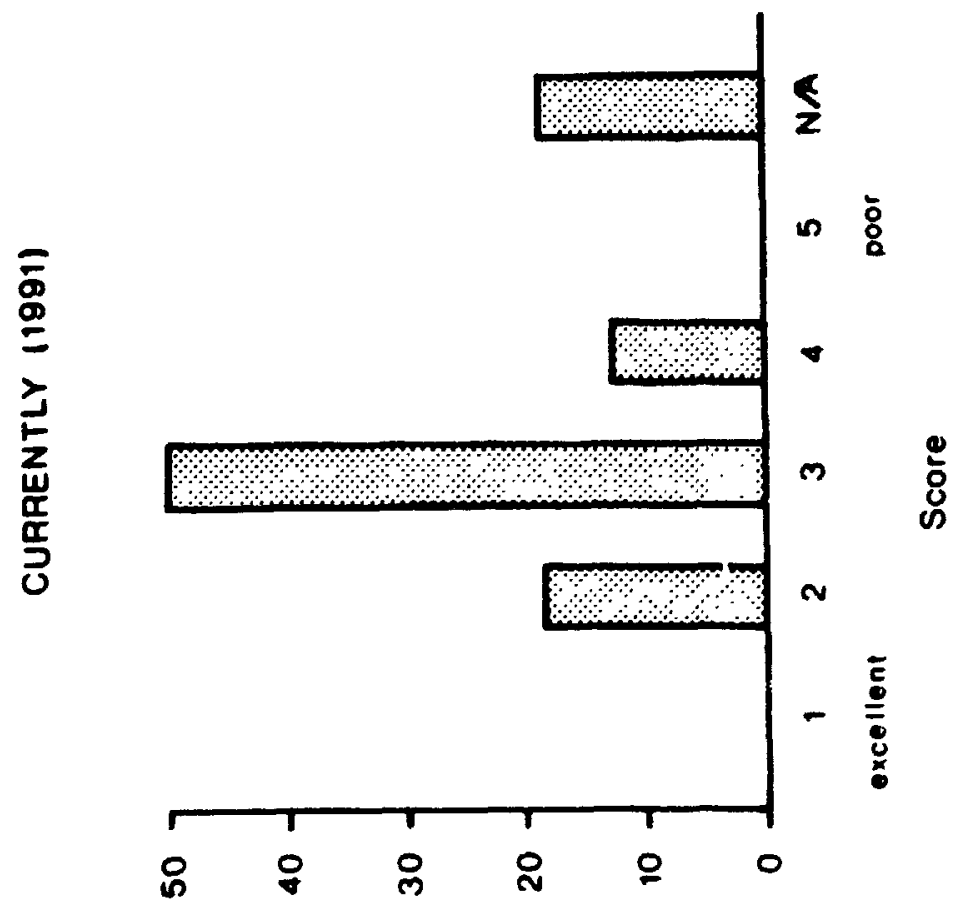

Percentage of Respondents 
$n$
$\dot{w}$
$\frac{\pi}{5}$
$\frac{0}{u}$

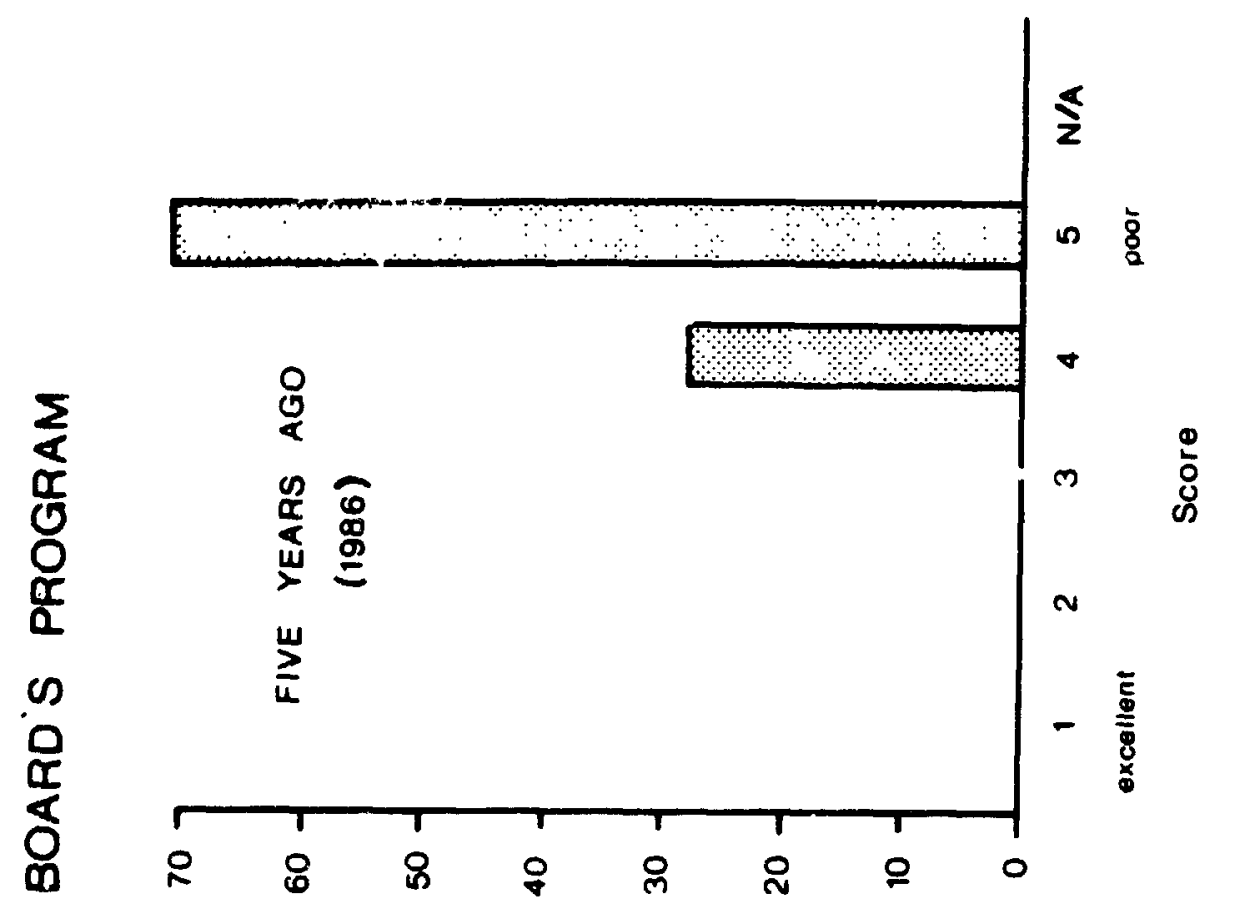

$\frac{11}{E}$

Percentage of Respoindents

范

$\frac{\mathfrak{Z}}{2}$

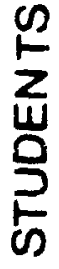
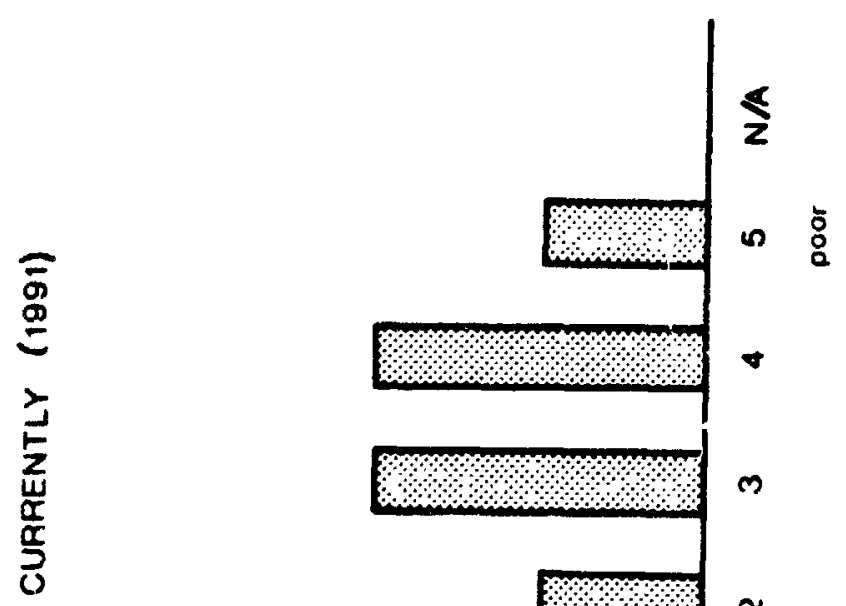

M $\quad \begin{aligned} & 0 \\ & 0\end{aligned}$

N

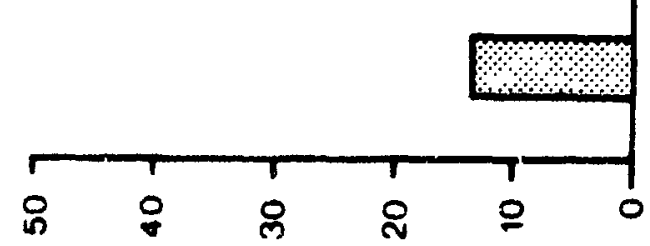

$-\quad \frac{\bar{\sigma}}{\bar{\delta}}$

Percentage of Respondents 
The students seem somewhat undecided as to how they see the environmental education program in their Board. Responses ranged from excellent to poor. The teachers, on the other hand, saw the program as average. The teachers felt that the program was doing acceptably well, but could stand improvement. The student who indicated that the program was excellent qualified the response by saying that "awareness was excellent", but that "action was poor" and that the Board needed to stop talking and start doing. The students saw environmental issues being discussed at school, at home, anò in the media, but little action being taken. The student who indicated that the program was poor stated that there was too much talk and not enough action. This student had the same complaint as the previous student, tut articulated it differently.

The way the students and teachers see the environmental education program at the Board is coloured by their past experience. Many teachers can remember a time when environmental awareness was not an issue. While students have grown up in a time of environmental consciousness raising and therefure have a different experience to draw from. Students, in general, see the school system lagging behind the environmental movement that is so prevalent in the media and our society today.

The participants were asked if improvements to the program were still needed (question B8). The overwhelming 
response was "yes"; one respondent answered "not sure", all the others, 97.1\%, answered "yes". Suggestions for improvement included the following: improve curriculum (8.68), encourage a lifestyle change (8.6\%), better inform teachers (5.7\%), develop more hands on activities, follow through on policies, and encourage students and teachers to be more environmentally friendly in their daily activities $(14.38)$.

students were the most discouraged group interviewed. Being on the receiving end of the program, they felt that they were not being given enough information on current environmental issues. Students voiced concern over the "do as I say not as I do" syndrome. They felt that the teachers were telling them that they had to live one way while they, the teachers, were living a different way.

When asked to comment on what, specifically, is lacking from the Board's curriculum (question B11) the interviewees raised, among others, the issues of lack of resources (14.3\%), money ( $8.6 \%)$ and the fact that environmental issues need to be stressed more throughout the curriculum (20\%).

Looking toward the future, the respondents were asked where they felt environmental education was heading in the next few years (question B10). Many of the respondents felt that environmental education would be integ. ted more thoroughly throughout the curriculum (28.68), more courses related specifically to the environment would be offered 
(17.1\%) and also a better educated public would lead to more positive action (208).

The last question in the interview guide was open ended and gave the respondents an opportunity to make any other comments they felt relevant (question B12). The most disheartening of the comments was made by the Chairman of the CRCSB when he said simply: "We're too late." He feels that we are srying, in the eleventh hour, to change hundreds of years of history. Our society has not developed into the "consume and dispose" society it is over night. We have spent hundreds of years refining the "art" of wastefulness and it will take more than a few years to change. The Chairman simply is not sure we can change quickly enough.

Several of the questions asked during the interviews were not reported on because the information they collected was irrelevant in retrospect. They are: points "d" and "e" from question $A 8$ and question $A 9$.

\subsection{DATA INTERPRETATION}

From the data collected for this project it is obvious that the Board is putting a great deal of effort into becoming an environmentally aware institution. The biggest factor in this respect is the Environment committee itself. Since its inception in 1989, a great deal of work has been done to develop an environmental etric within the Board. As discussed 
in the previous chapter, specific policies have been created that strive to include environmental issues within the curriculum wherever possible (CRCSB 1991C) and worthwhile environmental projects have been encouraged (CRCSB 1989b, 2).

Even though the respondents indicated that environmental education started at a grassroots level, in the classrooms and schools in this case, they felt the Board had recently taken a far greater responsibility for eivironmental education. Figure 5.3 illustrates how respondents perceived the Board's program 5 years ago (1986) and at the time of the survey, in the spring of 1991. The figures indicated that participants felt the program had improved but that there was still room for improvement.

The only discouraging voice seems to be that of the students. Overall, they felt that the Board had not done nearly enough to encourage and include environmental issues in the curriculum. Students reported that they felt the Board was approaching this as a "fad" or "the issue of the month" and that teachers were not taking environmental concerns seriously.

It is unfortunate that the students could not see what was taking place in their classrooms ten or fifteen years ago. They would quickly realize that many things have changed and environmental awareriss is taken far more seriously than it was then. At that time the environment was never mentioned in the context of "preservation" and / or "sustainability". It 
was only mentioned in terms of what we could harvest from it (eg. trees, fish, mineral deposits). Very little distinction was made between renewable and nonrenewable resources.

\subsection{PROBLEMS WITH DATA COLLECTION}

Even though a pretest had been undertaken and the interview guide modified to reflect the results of this test some problems with the data collection tool became evident.

The same guide was used for each interview. In retrospect a separate guide should have been designed for the students. They seemed to have concerns somewhat different from those of their elders. The students were less concerned about what the Board was doing and more concerned about what the Board could or should be doing. They wanted more of an opportunity to offer their suggestions for improvement.

In retrospect, the interview guide should have been designed a little differently. Several of the questions that appear in Part B of the guide ask people for their personal opinion on issues not related to the Board's program (questions B3, B4 and B5) and therefore should have been addressed in Part $A$. The portion of $A 6$ that dealt with environmentally friendly transport should have been presented differently. The question shouid have been simply: "Do you use environmentally friendly transport (examples: bus, bike, small car). As well, points "d" and "e" from question A8 and 
question A9 should have been eliminated. They did not contribute to the aim of the paper and were simply not reported on for this reason.

The interviewees were selected to ensure that persons from all levels of the board had a chance to contribute. The interview process itself was very time-consuming and, unfortunately, time constraints did not allow for as many interviews as the researcher would have liked. At least double the number of interviews would have been preferable. 


\section{CHAPTER SIX}

\section{CONCLUSIONS AND RECOMENDATIONS}

\subsection{REITERATION OF THE AIM}

Conclusions and recommendations can be drawn with respect to two of the questions stated at the beginning of this paper: 1) is the environmental education program of the CRCSB meeting Ministry of Education requirements; and 2) are the students, the users, satisfied with the program. As a result of the research done, some comments can also be made about the Ministry of Education requirements.

The third question: "What is the environmental education program, formal and informal, at the CRCSB?" is discussed at length in chapter Four. It is simply a description of the program. The evaluation occurs when the program is compared to the Ministry of Education requirements. Conclusions and recommendations are made on the basis of this comparison.

\subsection{CONCLUSIONS}

The examination of the CRCSB's program in terms of the Ministry expectations has proved almost impossible. The Ministry has, as yet, not fully developed a policy on environmental education, so trying to measure conformance with an incomplete policy is very difficult. One can look at many of the curriculum guide...nes and read a great deal of 
environmental awareness into them or very little. It all seems to depend on how you, as a board or teacher, interpret the guidelines.

The only signs that the Ministry has made a commitment to the environment are: 1) the twelfth goal of education "develop respect for the environment and a commitment to the wise use of resources" (Ontario Ministry of Education 1989, 3); and 2) the, as yet unpublished, document by Smith (1991).

At the board level, the CRCSB has taken the curriculum guidelines and tried to read as much environmentalism into them as possible. Efforts have been made on the part of the Board to ensure that their students become environmentally conscious. The Board established an Environment committee in 1989 with the following mandate:

1. To develop a CRCSB mission statement concerning environmental issues.

2. To review the curriculum involving environmental issues and to make recommendations concerning content, resources, and facilities in the elementary and high school.

3. To identify and promote environmental

initiatives which can be readily implemented. (CRCSB 1989b, 2).

Since its inception, the committee has worked to filfill its mandate. It has developed firm policy statements with respect to the environment (CRCSB 1991C). The committee has also been instrumental in establishing a Board-wide recycling program and co-ordinating professional development activities dealing with environmental education. 
with respect to the latter part of the aim, are the students satisfied with the program; the answer is no. The students who were interviewed 1 lt that the Board and Ministry were not doing enough to encourage environmental awareness in the schools (100\%). Students repeatedly cited the use of styrofoam in tho cafeterias $(71.48)$, the requirement to use one side of a page of paper $(42.98)$, and the teacher's seeming lack of knowledge of and concern for the environment (42.98).

\subsection{RECOMMENDATIONS}

The Ministry needs to develop a much more explicit policy with respect to environmental awareness. It has begun to develop courses, but more work needs to be done. Some suggestions for improvement can be made. First, the Ministry could develop a curriculum ideas pamphlet for teachers on environmental issues similar to the pamphlet published on the use of road maps (Ontario Ministry of Education 1987). The Carleton Board of Education has already created two helpful booklets for its teachers at the Junior level: How Can I Make a Difference? (Smith 1990) and Ecocentre Activity Package (McLellan 1990). Both these booklets contain a collection of ideas to help children develop environmental awareness, and the knowledge needed to put that awareness into action.

A second suggestion would be to include environmental studies/education as a required part of the program, much like 
mathematics and arts which both have a minimum of 120 hours of instructional time per year at the Grade 7 and 8 level (Ontario Ministry of Education 1989,15$)$.

Lastly, the Ministry needs to try to include environmental concepts in every course it administers. Environmental awareness needs to become a way of life within our school system. This can only be accomplished by including environmental issues wherever possible.

From the research done, the CRCSB is making a good attempt at incorporating environmental awareness in its curriculum. The best recommendation that can be made here is to keep trying. Only with time and persistence will environmental ideals permeate the Board. It's nut something that will happen over night.

The Board may wish to re-examine its goals and mandate. Currently, environmental awareness is only addressed in a subsection of Goal 2. With the focus that the Board has placed on environmental education in the last couple of years, it may wish to change its goals and mandate, or add to them, to reflect the current thinking of the Board.

It is unfortunate that the students of the CPCSB see their program as so lacking. They must be patient. Change takes time. If the students are really committed to environmental awareness they, themselves, can work to make the system change. They can encourage their teachers and the 
school staff and administration to become more environmentally aware. They, the students, can become change agents.

\subsection{LIMITATIONS OF THE STUDY}

There are several problems that arose during the course of the study that in some way limited it. First, the researcher had a far too ambitious idea of what could be accomplished in the time allowed. The desire to evaluate the entirety of the CRCSB's environmental education program was overly ambitious. In retrospect a smaller section of the program should have been chosen for examination (eg. the elementary or secondary program, or even the program at a specific grade). This would have produced a far more in depth evaluation than the one presented here.

A second, and unexpected, Iimitation to the study was the lack of sim:lar studies. An exhaustive search of the literature was undertaken and no studies were found that were of a similar nature. Many studies and articles were found that dealt with specific environmental issues and the ways in which specific schools and school boards handled these issues, but nothing was found that discussed an entire environmental education program at a school board.

The absence of similar studies limits the extent to which these findings can be compared to other situations. It would have been helpful to know what other school boards are doing 
and how their programs differ from what the CRCSB is doing. Such studies would have made other, more useful recommendations possible.

\subsection{FUTURE DIRECTIONS OF RESEARCH}

Several issues were raised during this investigation that could be examined in the future.

Since the students interviewed were so unhappy with their education, the following question should be addressed: "What do the students want to see in their program?" During the course of this research several students offered quite insightful ideas. For example, one student suggested that a forum be established of students from different schools in the area. The students could get together on a regular basis and exchange ideas on the environment and encourage each other in their environmental endeavours. A second student suggested that it was time to stop talking and start doing. They suggested that students be allotted school time for environmental activities such as cleaning up a local creek or planting trees.

The school environment needs to be examined as well. "Why are school cafeterias still using styrofoam?" "Is there a reason for having so many lights on all the time?" The Board needs to conduct an environmental audit. It needs to look at what the most environmentally friendly options are and 
incorporate as many of these as possible into its daily life. Perhaps styrofoam containers cost the environment less than reusable china containers in the long run. Each option needs to be examined fully to deternine which is "actually" best. A comparative study of the different boards in the ottawa area would allow the researcher to see what is being done by the different administrations. "Is one program better than the others?" "Are there aspects from several programs that could be combined to create a superior environmental education prog:am?" 

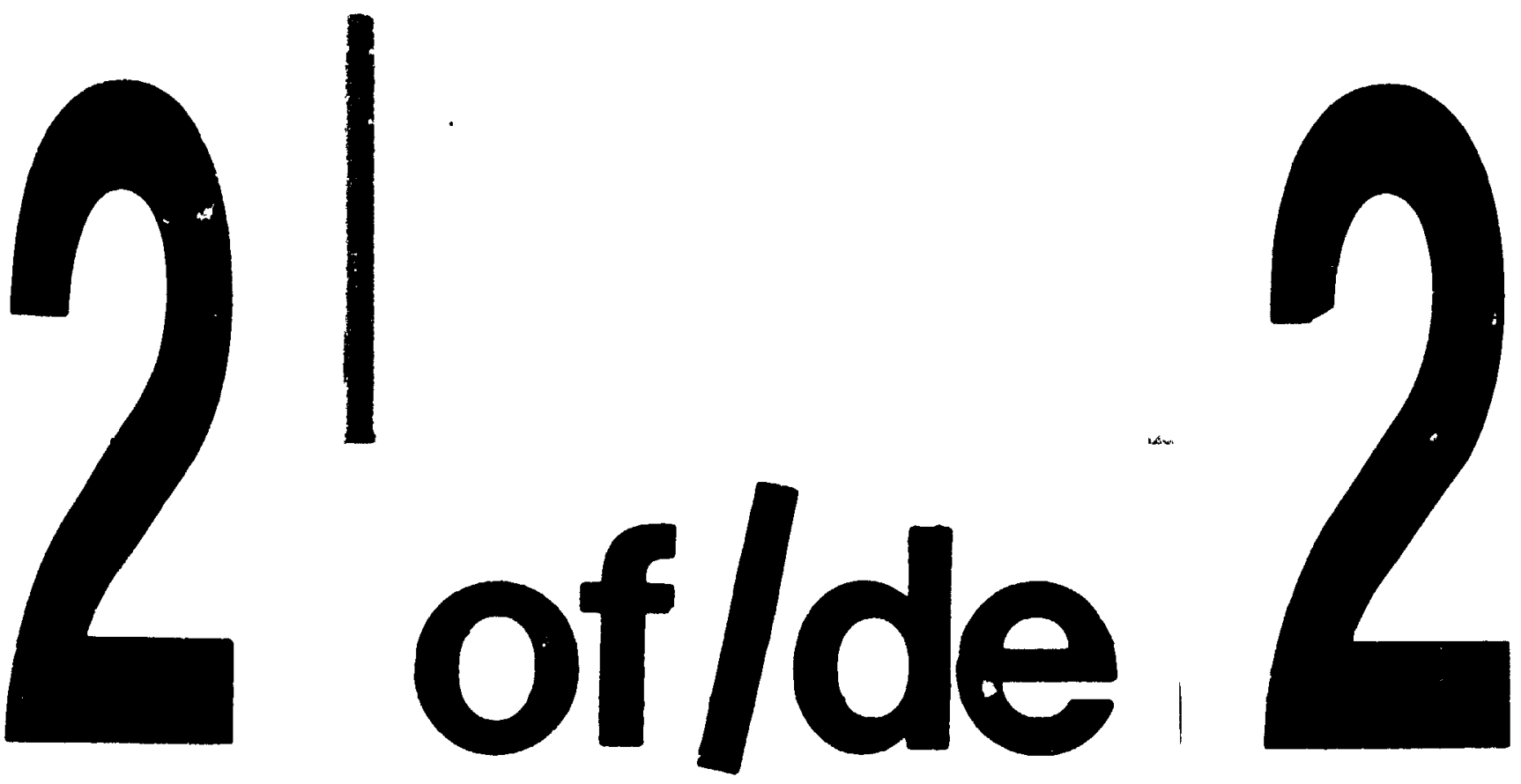

[PM-1 31\%2"X4" PH:OTOGRAPHIC MICROCOPY TARGET NBS 10100 ANSI/ISO *2 EOUIVALENT

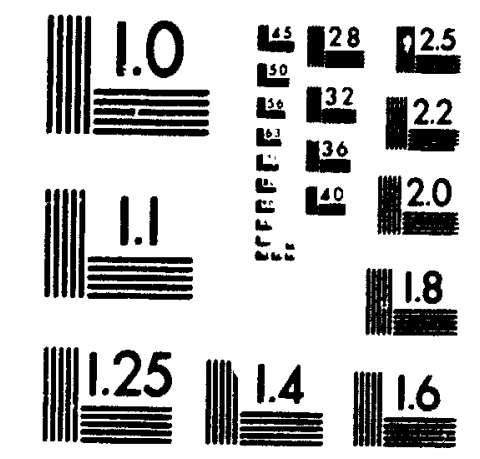

PAECISIONEm RESOLUTION TARGETS

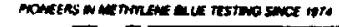


APPENDIX A

March 1991.

Dear Participant:

As per our telephone conversation, I am conducting research on the environmental education program of the Carleton Roman Catholic School Board as part of the requirements for my Masters in Geography. The primary objective of this research is to determine the extent to which the Ministry of Education guidelines provide direction in environmental education and how this is interpreted by the school board.

The interview, which you have agreed to participate in, will take roughly forty five minutes. I will be asking you questions related to environmental education practices at the Boara, as well as your environmental practices while on Board related activities. I would hope to be able to use any of the material gathered freely in my research. If you would rather I not use your name at all or in reference to any particular statement I will respect those wishes and your comments will remain anonymous.

Thank you for your time and participating in my research. If you have any questions feel free to contact me or my advisor at the following numbers:

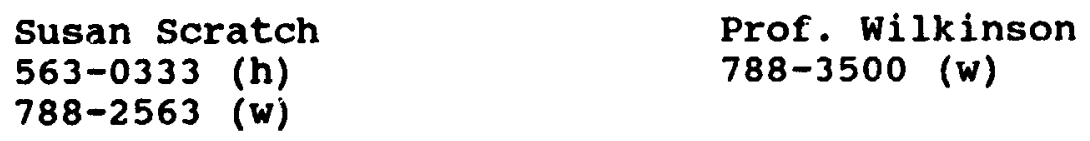

I plan to create an executive summary of my work for Board use. If you would like a ropy of this summary please let me know.

Sincerely

Susan Scratch 
PART A - PERSONAL INFORMATION

1. Name.

2. Position.

3. Educational Background.

4. Number of years with the Board.

5. Do you consider yourself environmentally aware?

$\begin{array}{ccccc}\text { very } & & & \text { not at all } \\ 1 & 2 & 3 & 4 & 5\end{array}$

Why did you put yourself in this category?

6. So much of what we do in schools is modeled by our students. DC you practice the following while conducting Board related activities:

$$
\text { always never }
$$

conservation of:

$\begin{array}{llllll}\text { paper } & 1 & 2 & 3 & 4 & 5 \\ \text { energy } & 1 & 2 & 3 & 4 & 5\end{array}$

recycling of:

$\begin{array}{llllll}\text { paper } & 1 & 2 & 3 & 4 & 5 \\ \text { glass } & 1 & 2 & 3 & 4 & 5 \\ \text { tin } & 1 & 2 & 3 & 4 & 5 \\ \text { age free lunches } & 1 & 2 & 3 & 4 & 5\end{array}$


reusable containers

$\begin{array}{lllll}1 & 2 & 3 & 4 & 5\end{array}$

environmentally friendly transport:

$\begin{array}{llllll}\text { bus } & 1 & 2 & 3 & 4 & 5 \\ \text { walking } & 1 & 2 & 3 & 4 & 5 \\ \text { small car } & 1 & 2 & 3 & 4 & 5 \\ \text { car pool } & 1 & 2 & 3 & 4 & 5 \\ \text { bicycle } & 1 & 2 & 3 & 4 & 5\end{array}$

7. When did you first become aware of the need for environmental awareness education?

When did you begin to encourage/include environmental education concepts in your activities?

8. Have you attended any environmental awareness workshops?

If yes, how many in the last five years?

Content and structure? 
Overall, were the ideas and materials useful?

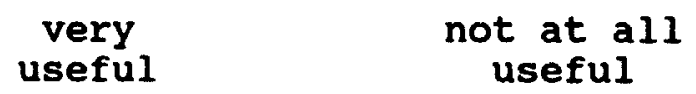

How frequently do you use this information?

\begin{tabular}{ccccc} 
always & & & \multicolumn{3}{r}{ never } \\
1 & 2 & 3 & 4 & 5
\end{tabular}

9. Have you participated in the development of environmental awareness education curriculum, courses, or units?

If yes, please elaborate. 
PART B - THE PROGRAM

1. In the URCSB, at what level do you feel the movement to include environmental concepts in the education program started?

the classroom

- subject area

- school

- department

- the Board staff and administration

- the Board trustees

- the Ministry

2. Do you feel the Board is taking more responsibility for environmental education than it has in the past?

In what respects?

3. At what age should environmental 'awareness' concepts be introduced?

Why? 
4. Do you feel that environmental awareness should be taught:
- throughout the curriculum, as a component of every class throughout the curriculum, as a way of life as a separate course

Comments.

5. What is your current involvement in the environmental awareness education program?

Is your involvement due to job requirements?

If no, please specify.

6. From your point of view, do you feel the Board's current environmental awareness education program is:

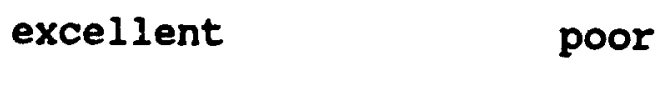

$\begin{array}{lllll}1 & 2 & 3 & 4 & 5\end{array}$

Comments. 
7. Using the same scale, five years ago was the Board's environmental education program:

excellent poor

$\begin{array}{lllll}1 & 2 & 3 & 4 & 5\end{array}$

8. Are improvements to the program needed?

Suggestions.

9. Do you feel most teachers are well informed about environmental issues?

If not, how can they be better informed?

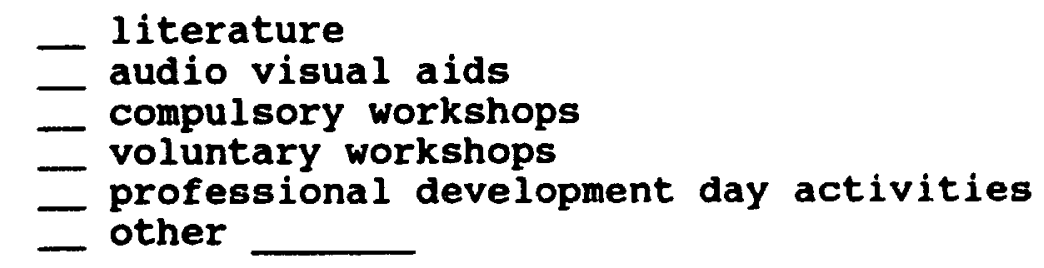

Who should pay?

Whose responsibility should it be? 
10. Where do you see environmental education heading in the next few years?

11. What do you feel is lacking from the curriculum the Board currently offers?

12. Any other comments, questions or concerns? 
APPENDIX B

TO: The Ethics Committee

March 15, 1991.

c/o Anne Burgess

FROM: Susan Scratch

Geography Department

RE: Approval for M.A. Thesis

Thesis Title:

The Environmental Education Program of the

Carleton Roman Catholic School Board

- A Case Study -

Proposed Research:

I will be examining the environmental education program of the Carleton Roman Catholic School Board (CRCSB) with the main focus of the investigation being the extent to which the Ministry of Education guidelines provide direction in environmental education and how this is interpreted by the school board.

The investigation will begin with a review of pertinent literature including a review of appropriate Ministry of Education documents. I will then interview representatives of all levels of the school board as well as members of the Board's Ad Hoc Environmental Committee. Currently, I plan to interview representatives from each of the following areas: trustees; superintendents; co-ordinators; consultants; principals; department heads; teachers, both elementary and secondary; and students.

The issues/questions I plan to address in my interviews are attached at the end of this letter.

I have spoken to Mr. Vic D'Amico, superintendent of secondary programs, of the CRCSB and he has offered to facilitate my study of the Board's environmental awareness program. He has agreed to arrange appointments for interviews for me with the proponents mentioned above. Also, Mr. D'Amico has offered to include my questionnaire as an item on the April agenda of the Environment Committee (they meet the fourth Monday of each month). I would, therefore, greatly appreciate having your approval by the third week of April to allow me time to properly prepare for the meeting.

Thank you for your time and quick response. 


\section{FACULTY OF GRADUATE STUDIES AND RESEARCH}

MEMOR A N D U M

DATE: $\quad$ April 1, 1991.

TO: $\searrow_{\text {Susan Scratch }}$

Prof. Tom Wilkinson

Dept. of Geography

FROM: Anne Burgess

University Research Officer

RE: $\quad$ Ethics Clearance

The University Ethics Committee has reviewed Ms. Scratch's research proposal, and has found it to be ethically acceptable.

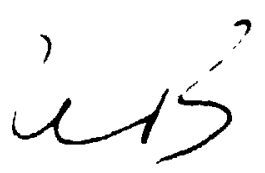

A.B. 
APPENDIX $C$

May 1, 1991.

\begin{abstract}
THE ENVIRONMENTAL EDUCATION PROGRAM OF THE CARLETON ROMAN CATHOLIC SCHOOL BOARD

- A CASE STUDY -
\end{abstract}

Proposed Research:

I will be examining the environmental education program of the Carleton Roman Catholic School Board (CRCSB). The main focus of the investigation is the extent to which the Ministry of Education guidelines provide direction in environmental education and how this is interpreted by the School Board.

The investigation will begin with a review of pertinent literature including a review of appropriate Ministry of Education documents. I will then interview representatives of all levels of the School Board as well as members of the Board's ad hoc Environmental Committee. Currently, I plan to interview representatives from each of the following areas: trustees; superintendents; co-ordinators; consultants; principals; department heads; teachers, both elementary and secondary; and students.

I have spoken to Mr. Vic D'Amico, superintendent of Secondary Programs, and he has offered to facilitate my study of the Board's environmental awareness program. He has agreed to arrange appointments for interviews for me with the parties mentioned above.

What I hope to gain by coming here tonight and presenting my research proposal to you are any ideas or suggestions you may have regarding my proposed research. Am I omitting questions? Is there a particular issue that the committee would like to see investigated that I could tie into my work? Equally, are there any concerns about my proposal that you would like to raise at this time?

The issues/questions I plan to address in my interviews are attached at the end of this letter.

Thank you for your time. If you have any questions or comments or wish to volunteer to take part in my research please feel free to contact me at any time. 


\section{APPENDIX D}

THE GOALS OF EDUCATION ${ }^{1}$

The Ministry of Education in Ontario strives to provide in the schools of the province equal opportunity for all. In it's contribution to programs, personnel, facilities, and finances, the ministry has the overall purpose of helping individual learners to achieve their potential in physical, intellectual, emotional, social, cultural, and moral development. The goals of education, therefore, consist of helping each student to:

1. develop a respo: iveness to the dynamic processes of learning

Processes of learning include observing, sensing, inquiring, creating, analysing, synthesizing, evaluating, and communicating. The dynamic aspect of these processes derives from their source in many instinctive human activities, their application to real-life experiences, and their systematic int srrelation within the curriculum.

2. develop resourcefulness, adaptability, and creativity in learning and living

These attributes apply to modes of study and inquiry, to the management of personal affairs such as career plans and leisure activities, and to the ability to deal effectively with challenge and change.

3. acquire the basic knowledge and skills needed to comprehend and express ideas through words, numbers, and other symbols

Such knowledge and skills will assist the learner in applying rational and intuitive processes to the identification and solution of problems by:

a) using language aptly as a means of communication and an instrument of thought;

b) reading, listening, and viewing with comprehension and insight;

1 The Goals of Education have been copied from the Ontario Ministry of Education publication ontarie Schools: Intermediate and Senior Divisions (Grades 7-12/0ACs) (1989, 3). 
c) understanding and using mathematical operations and concepts.

4. develop physical fitness and good health

Factors that contribute to fitness and good health include regular physical activily, an understanding of human biolugy and nutrition, the avoidance of health hazards, and concern for personal well-being.

5. gain satisfaction from participating and from sharing the participation of others in various forms of artistic expression

Artistic expression involves the clarification and restructuring of personal perception and experience. It is found in the visual arts, music, drama, and literature, as well as in other areas of the curriculum where both the expressive and receptive capabilities of the learner are being developed.

6. develop a feeling of self-worth

Self-worth is affected by internal and external influences. Internally it is fostered by realistic self-appraisal, confidence and conviction in the pursuit of excellence, selfdiscipline, and the satisfaction of achievement. Externally it is reinforced by encouragement, respect, and supportive evaluation.

7. develop an understanding of the role of the individual within the family and the role of the family within society

Within the family the individual shares responsibility, develops supportive relationships, and acquires values. within society the family contributes to the stability and quality of a democratic way of life.

8. acquire skills that contribute to self-reliance in solving practical problems in everyday life

These skills relate to the skilful management of personal resources, effective participation in legal and civic transactions, the art of parenthood, responsible consumerism, the appropriate use of community agencies and services, the application of accident-prevention techniques, and a practical understanding of the basic technology of home maintenance. 
9. develop a sense of personal responsibility in society at the local, national, and international levels

Awareness of personal responsibility in society grows out of knowledge and urderstanding of one's community, one's country, aind the rest of the world. It is based on an understanding of social order, a respect for the law and the rights of others, and a concern for the quality of life at home and abroad.

10. deve,op esteem for the customs, cultures, and beliefs of a wide variety of societal groups

This goal is related to social concord and individual enrichment. In Canada it includes regard for:
a) the Native peoples;
b) the English and French founding peoples;
c) multiculturalism;
d) national identity and unity.

11. acquire skills and attitudes that will lead to satisfaction and productivity in the world of work

In addition to the appropriate academic, technical, and interpersonal skills, this goal relates to good work habits, flexibility, initiative, leadership, the ability to cope with stress, and regard for the dignity of work.

12. develop respect for the ervironment and a commitment to the wise use of resources

This goal relates to a knowledgeable concern for the quality of the environment, the careful use of natural resources, and the humane treatment of living things.

13. develop values related to personal, ethical, or religious beliefs and to the common welfare of society

Moral development in the school depends in part on a consideration of ethical principles and religious beliefs, a respect for the ideals held by others, and the identification of personal and societal values.

The preceding goals are not arranged in any hierarchical order, nor are they discrete categories from which a checklist 
should be made. The integrated nature of learning and the complex pattern of human development preclude such a sequential or fragmented approach. The translation of the goals into curriculum objectives, however, will undoubtedly result in sequences of learning appropriate to the particular levels and stages of development of the students for whom programs are being planned. 


\section{APPENDIX E}

THE KEY CONCEPTS OF ENVIRONMENTAL EDUCATION ${ }^{1}$

1. The Planet is a closed system: the concept of Bcosyston Factors: sunshine, rain, temperature, wind, energy, soil, plants, animals, fungi

Everything is oomnocted to everything else

Renowable/Mon-Renewable resources

2. Human Intoraction with the environment: every action has an impact

Personal Awareness of these impacts Effect of consumer and market forces

Energy required to sustain current way of life: global warming

3. Cyoles:

Natural Cycles: water, nutrients, life-death, Jrowthdecay, carbon-oxygen, etc.

4. Managanont of environment and resources for long term sustainability

Efficient use of resources

Harvesting: - plants and animals, domestic and wild

- population control / carrying capacity

- predator-prey relationships

Farm/wildlife preserves as examples of a simplified ecosystem/shortened food chain

High productivity, modern technology and economic

development must co-exist with a healthy environment

5. Interaction of Bconomics, Bcience

(Biology/Chonistry/Physics; and Politics in

environmental issues: Integration of learning about our world

6. Habltat: Importance of food, water, shelter, space for personal/human/animal survival

Food is not magic; trace its path

Water is not magic; trace its path

Garbage and sewage disposal is not magic: follow it

A healthy, beautiful environment is a basic human need

1 The Key Concepts of Environmental Education have been copied from ontario Ministry of Education: Environmental Education: Summary of Curriculum: $K$ to OAC (Smith 1991, 9). 
7. Food wobs and chains: biological magnification of contamination

8. Complexity of decision-making on environmental issues Lack of precise information and knowledge of how the world works

Invisibility of many problems or damage: water pollution

Long range and/or unintended effects

9. Hope: Natural Rehabilitation and Regeneration from environmental damage

"The environment is resilient but has its limits"

Individuals can make a difference; success stories

10. Personal comitment for the care and reapect of the environment

Reduce, Reuse, Recycle, Rethink as a way of life Environmental ethics in your job and family life Minimize use of substances harmful to the environment: chemicals, pesticides, insecticides, CFC's, home products

Respect for all living things 
APPENDIX F

ENVIRONMENTAL ISSUES ${ }^{1}$

1. Growth of the Human Population

2. Global Warming

3. Destruction of the ozone layer

4. Vanishing Forests

5. Acid Rain

6. Biotechnology

7. General Environmental Deterioration

8. Species extinction and wildlife conservation: loss of genetic diversity

9. Soil degradation and erosion due to construction and modern agriculture methods

10. Disappearance of prime agricultural land

Urban Sprawl

11. Disappearance of wetlands

12. Waste Disposal

Hazardous wastes: domestic, industrial, nuclear Solid wastes: domestic, industrial, land fill, incineration, recycling Agricultural Wastes: manure, fertilizer, pesticide run-off

13. Air Quality

14. Water Quantity and Quality

15. Effective management of the environment and resources for sustainable development

1 Copied from ontario Ministry of Education: Environmental Education: Summary of curriculum: $K$ to OAC (Smith 1991, 11). 
16. Hunger/chronic malnutrition: distribution of the world's food and wealth

17. Place of people on the globe in respect of other living things: Respect for other living things 


\begin{abstract}
APPENDIX G
ENVIRONMENTAL LEARNING OPPORTUNITIES AFFORDED

TO CHILDREN IN THE PRIMARY AND JUNIOR DIVISIONS ${ }^{1}$
\end{abstract}

\title{
PRIMARY DIVISION:
}

Children shall have opportunities to:

- demonstrate concern and care for the environment and respect for all life

- become aware of some of the machines and tools that are used to maintain a safe, clean environment

- observe and describe a wide variety of living things

- observe the growth and development of common animals and common plants

- care for an animal and a plant over a period of time

- use materials to replicate a natural environment

- explore ways in which living things adapt to their natural environment in order to survive

- investigate the needs of animals and plants and how they are met

- observe and describe weather conditions and changes

- observe and describe a variety of indicators of seasonal change

- predict change on the basis of observations of the environment

- develop time lines to track and record observed events in science

- observe and describe simple changes (snow to water, etc)

- use devices that employ various forms of energy

- develop awareness of their role in the wise use of energy

- identify devices that may help conserve energy.

\section{JUNIOR DIVISION:}

Children shall have opportunities to:

- demonstrate concern and care for the environment

- investigate ways to care for the environment

- observe, describe, and compare a wide variety of plants

1 The following is copied from the ontario Ministry of Education document ontario Ministry of Education: Environmental Education: Summary of curriculum: $\mathrm{K}$ to OAC (Smith 1991, 4). 
and animals common to the immediate environment

- develop their own simple systems for classifying plants and animals

- investigate the life cycles of some common plants and animals

- use materials to replicate a natural environment

- observe and describe plants and animals peculiar to a particular habitat

- observe the ongoing process of change in a natural community

- design and perform an experiment involving seed germination or plant growth

- identify relationships among living things

- investigate ways in which people affect plant and animal life

- investigate human dependence on plants and animals

- investigate at least one of the following from the local environment: rocks and minerals, fossils, soils

- use devices appropriate to the investigation of rocks and minerals, fossils, or soils

- observe and describe a variety of weather conditions and suggests ways of predicting weather

- design, construct, and use simple weather instruments

- identify ways in which weather conditions affect their lives

- use appropriate materials to explore the nature and movement of air

- observe cyclic occurrences in their lives and in the natural world

- develop an awareness of the movement of the earth that results in day and night and the seasons

- investigate the physical properties of one or more materiais

- design and perform an experiment to explore a causeand-effect relationship

- explore the characteristics and properties of one or more forms of energy

- identify devices used to conserve energy

- demonstrate their role in the wise use of energy. 


\title{
APPENDIX H \\ LIST OF CARLETON ROMAN CATHOLIC SCHOOL BOARD SCHOOLS - BY SCHOOL FAMILY ${ }^{1}$
}

\author{
HOLY TRINITY FAMIEY OF SCHOOLS \\ Holy Trinity High School \\ 180 Katimavik Road, Kanata \\ Georges Vanier \\ 40 Varley Drive, Kanata
}

Holy Redeemer

75 Mccurdy Drive, Kanata

Holy Spirit

1383 Main street, stittsville

st. Isidore

1105 March Road, Kanata

st. Martin de Porres

20 McKitrick Drive, Kanata

st. Michael (Corkery)

1572 Corkery Road, Carp

st. Michael (Fitzroy)

159 Charles street, Fitzroy Harbour

LESTER B. PEARSON FAMILY OF SCHOOLS

Lester B. Pearson High School

2072 Jasmine Cresent, Gloucester

Chapel Hill Catholic

1534 Forest Valley Drive, Orleans

Elmridge Catholic

1923 Elmridge Drive, Gloucester

Good Shepherd Catholic

101 Bearbrook Road, Gloucester

1 Taken from Welcome to the Board (CRCSB 1991a). 
Pineview Catholic

1500 Beaverpond Drive, Gloucester

Thomas D'Arcy McGee Catholic

635 Laverendrye Drive, Gloucester

ST. MARK FAMILY OF SCHOOLS

St. Mark High School

1040 Dozois Road, Manotick

st. Bernard

1722 st. Bernard street, Gloucester

st. Catherine

2717 Albert Street North, Metcalfe

st. Leonard

5344 Long Island Drive, Manotick

st. Mary

5536 Bank Street, Gloucester

st. Philip

79 Maitland st., Richmond

ST. MATTHEW FAMILY OF SCHOOLS

st. Matthew High School

6550 Bilberry Drive, Orleans

Blessed Kateri Tekakwitha

6400 Beausejour Drive, Orleans

Convent Glen Catholic

6212 Jeanne d'Arc Boulevard, Orleans

Divine Infant

8100 Jeanne d'Arc Boulevard, Orleans

Our Lady of Wisdom

$1565 \mathrm{st}$. Georges street, Orleans

St, Francis of Assisi

795 Watters Road, Orleans 
ST. PAUL FAMILY OF SCHOOLS

st. Paul High School

411 Seyton Drive, Nepean

Bayshore Catholic

50 Bayshore Drive, Nepean

Our Lady of Peace

3877 Richmond Road, Nepean

St. Thomas

9 Leeming Drive, Nepean

ST. PIUS X FAMILY OF SCHOOLS

St. Pius $X$ High School

1481 Fisher Avenue, ottawa

Frank Ryan Senior Elementary

128 Chesterton Drive, Nepean

Pope John XXIII

165 Knoxdale Road, Nepean

st. Elizabeth Ann Seton

41 Weybridge Drive, Nepean

St. Gregory

70 Fieldrow street, Nepean

St. John the Apostle

30 Costello Avenue, Nepean

st. Monica

2000 Merivale Road, Nepean

st. Patrick

68 Larkin Drive, Nepean

st. Rita

1 Inverness Road, Nepean

Uplands Catholic

CFB Uplands, Gloucester

st. Nicholas Adult Day School

130 Lotta street, Nepean 


\section{APPENUIX I}

\section{GOALS OF THE CARLETON ROMAN CATHOLIC SCHOOL BOARD ${ }^{1}$}

1. The CRCSB provides a dynamic learning environment which promotes the fullest possible development of the individual, based on the teachings of the Catholic Church and the mandate of the Ministry of Education.

The Board is dedicated to:

- supporting schools and classrooms as faith communities where relationships are based on Gospel values

- viewing the learner as the focal point of the system

- promoting learning as a life-long process

- emphasizing high expectations for all and the value of academic excellence

- encouraging independent learners through the process of logical reasoning, critical judgement and collaborative problem solving.

2. The CRCSB fosters a love of learning by providing quality programs which enable students to grow spiritually, intellectually, physically, socially, and emotionally. The Board believes that all students be provided with opportunities to:

- develnp a love for, and an understanding of, the teachings of Jesus

- experience their faith through Scripture readings, prayer and liturgical celebrations

- develop the knowledge and skills of communication, mathematics, social sciences, science, arts and modern technologies

- develop physical fitness and health

- understand and fulfill their roles as individials within the family

1 Copied from the CRCSB pamphlet Realizing the Vision: Touching Tomorrow Today: Mission statement and Goals (CRCSB 1991b). 
- develop a healthy sense of self-worth and well-being

- participate in programs where their growth is regularly observed and monitored both formatively and summatively

- develop an awareness, knowledge, responsibility and appreciation of the environment.

3. The CRCSB recognizes the important contribution of the community, including industry and business, to educational excellence. Effective education is the result of a homeschool-church partnership which leads inevitably to stronger social and moral structures in our region, province, country and the world. The Board promotes:

- the community school as the basic structure for program delivery

- regular and open communication with all segments of the public

- fairness in its relations with students, parents or guardians, ratepayers, community, and school board personnel

- recognition of the multi-racial and multi-cultural nature of this region and appropriate educational programs and services

- understanding of the rights and responsibilities of canadian citizenship within the global community

- equal opportunity and affirmative action which address employment equity of staff

4. The CRCSB formulates and implements policies that support and facilitate the realization of its goals.

The Board is committed to:

- providing leadership in all areas of Catrolic education

- ensuring that all members of its educating coramunity (students, parents, staff and trustees) are treated with dignity and respect

- fostering positive attitudes toward the Board

- human resources planning and development through on-joing professional development and performance appraisal 
- ensuring that students, parents and staff are fully aware of it's objectives, services, activities, and accomplishments.

5. The CRCSB monitors and plans for growth in the system in order to provide appropriate accommodation for all students in the most effective way possible.

The Board is committed to:

- maintaining it's buildings and grounds at a high standard

- developing long-term plans to identify accommodation and program needs

- developing systems and procedures for the operation of school buildings

- monitoring and assessing costs and contractual services

- continuing liaison with the Ministry of Education, universities and other educational institutions. 
APPENDIX J

ENVIRONMENTAL EDUCATION AT THE

CARLETON ROMAN CATHOLIC SCHOOL BOARD ${ }^{1}$

PRIMARY - JUNIOR CURRICULUM

A. ATTITUDES

The primary and Junior Environmental Studies Programs attempt to develop the following attitudes in students:

- Awareness

- Concern and care for the envircnment

- Respect for living things

- Consideration for other

- Sensitivity

- Compassion

- objectivity

- Open-mindedness

These attitudes contribute to an understanding of the natural environment and how it affects and in turn is affected by human activities, past and present. students develop an early understanding of the relationships among natural things, among natural and manufactured things and between people and things.

\section{B. KNOWLEDGE/CONCEPTS}

$\begin{array}{cll}\text { Grade } & \text { Unit } & \text { Concept } \\ 1 & \text { Breaking out } & \text { Life cycles of animals. } \\ 1 & \text { Staying Alive } & \begin{array}{l}\text { Respect for living things. } \\ \text { Relationships between and } \\ \text { among living things and their } \\ \text { physical environment. }\end{array}\end{array}$

1 The following is taken from the CRCSB document Ecology and Applied Ecological Themes in the $K$ - OAC Curriculum. This document was distributed at the october 22, 1990 meeting of the Environmental Action Ad Hoc Committee. 
1 Talk to your Plant

1 Under Cover

$2 \quad$ Blooming

2 * wind and Weather

2 * Don't Look Now

2 Happy Habitats

3 Surviving

3 People Call it Home

3
Mother Nature's Recipes
Coverings protect plants from weather injury.

We need to keep our environment healthy.

Changes in the environment affect changes in an organism.

Weather is harmful and helpful.

Change in the environment may be sudden and unpredicated. Changes in the environment may be beneficial or detrimental. Change may occur as a result of technological advances.

All living things are independent.

We share our environment with a multitude of small animals.

Animals and plants change to suit environmental conditions. An animal's living space must provide food, water, shelter, and community.

People are producers and consumers.

A community has an effect on its surroundings.

Many non-living objects are made from living things. Soil, air, water, fuels, metals and gems are natural resources that must be conserved.

Living things depend upon one another and their non-living environment.

Nature has a definite order of balance.

A food chain demonstrates nature's balance. 
People can disrupt the balance or ensure its continuation through conservation. Everything becomes something else.

4

4

4

Blooming Blocks

4

5 Webs of Life

5 * Amazing Animals

6 Plants

6 Electricity
The sources and uses of energy at home and in school.

Insects depend on their environment for the necessities of life.

The conditions necessary for plant growth. How plants adapt to their ever changing environment.

Noise pollution is unpleasant sound.

Ways in which plants and animals interrelate within a community.

Nearly all living things are dependent on other living things for survival. Roles playad by producers, consumers and decomposers in a natural community. How the water cycle works. Man's role in air and water pollution.

Endanyered species are animals close to becoming extinct.

Plants interact with the environment. Plants are very useful to people and people can manipulate plants.

Conservation of our natural resources must be observed. 
6 Voyage of the Mimi

The manne environment: adaptation, temperature, storms, effects of pollution, research techniques.

Cycles of life: water cycle and food chains.

Solar heating and organic gardening.

$6 \star$ Soil

Humus is organic material present in soil.

Soil must be managed for conservation reasons. Soil can be considered an irreplaceable non-renewable resource because of its slow formation over long periods of time.

6 * Pond or Stream

Such ecosystems are in a study

delicate balance and conservation of such an environment must be preserved. Water is necessary for life. Every plant and animal occupies a niche in the ecosystem.

* This is an optional unit and as such is not studied by every class. 
INTERMEDIATE - SENIOR CURRICULUM

A. THE SCIENCE CURRICULUM

\begin{tabular}{|c|c|c|}
\hline Course & Unit & Topic/Concept \\
\hline \multirow[t]{5}{*}{$\begin{array}{l}\text { Grade } 7 \\
\text { Science }\end{array}$} & $\begin{array}{l}\text { Characteristics } \\
\text { of Living Things }\end{array}$ & $\begin{array}{l}\text { Role of living organisms } \\
\text { in/on our lives. }\end{array}$ \\
\hline & $\begin{array}{l}\text { Properties of } \\
\text { Matter }\end{array}$ & $\begin{array}{l}\text { Methods of acquiring and } \\
\text { separating substances may } \\
\text { have a detrimental effect } \\
\text { on the environment. eg. } \\
\text { strip mining. }\end{array}$ \\
\hline & $\begin{array}{l}\text { Conservation of } \\
\text { Energy }\end{array}$ & $\begin{array}{l}\text { Conservation attitudes, } \\
\text { skills and knowledge. }\end{array}$ \\
\hline & Chemicals & $\begin{array}{l}\text { Pollution of air and } \\
\text { water. }\end{array}$ \\
\hline & $\begin{array}{l}\text { Plants in our } \\
\text { Lives }\end{array}$ & $\begin{array}{l}\text { Knowledge, conservation } \\
\text { and appreciation of } \\
\text { plants in the } \\
\text { environment. }\end{array}$ \\
\hline \multirow[t]{3}{*}{$\begin{array}{l}\text { Grade } 8 \\
\text { science }\end{array}$} & Solutions & $\begin{array}{l}\text { Importance of water to } \\
\text { life. Pollution of } \\
\text { water. }\end{array}$ \\
\hline & $\begin{array}{l}\text { Investigating } \\
\text { Living Things }\end{array}$ & $\begin{array}{l}\text { Understanding of science } \\
\text { helps non-scientists } \\
\text { understand health and } \\
\text { environmental issues. }\end{array}$ \\
\hline & $\begin{array}{l}\text { Force Work and } \\
\text { Energy }\end{array}$ & $\begin{array}{l}\text { Benefits versus } \\
\text { environmental, economical } \\
\text { and societal } \\
\text { considerations of } \\
\text { technology. } \\
\text { Soil conservation, } \\
\text { agricultural pollution, } \\
\text { composting, etc. }\end{array}$ \\
\hline
\end{tabular}


Heat and

Temperature

Adaptations

Gardening

Grade 9B

Science

Grade 9G

Science Matter
Insulation of buildings, heat pollution, oil pollution, alternate energy sources.

Extinction of species. Damage caused by herbicides and pesticides.

Soil conservation, role of plants in our lives.

Properties of

Solubility of substances can cause water pollution, salt damage to cars, and gardens, along with bioaccumulation of toxic substances.

The Water World

Water pollution, water treatment.

Water pollution, water treatment. Problems associated with mixtures such as paint, solvents and pesticides.

Chemical Change

Cells and cell systems

Green Plants

Separation of substances
Problems associated with chemical disposal, including plastics. Greenhouse effect.

Effects of environmental changes (temperature, chemicals etc.) on cells and systems.

Role of plants in our lives. Deforestation, acid rain, agricultural pollution.

Separation of impurities from air and water. Recycling and resource recovery. 


\author{
Grade 9A \\ Science \\ Structure of \\ Matter \\ Disposal of solid, \\ liquid, and gaseous \\ waste. \\ Chemical Change \\ Chemical disposal and \\ pollution prevention. \\ Nuclear energy concerns. \\ Acid rain. \\ Green Plants \\ Deforestation, \\ urbanization problems, \\ biomass energy. \\ Agricultural pollution \\ and soil degradation. \\ Food and Energy \\ Environmental factors \\ that affect food \\ production. \\ Role of microorganisms in \\ food production. Energy \\ use in food production. \\ Pesticides and \\ fertilizers. \\ Science in Society Air pollution, harmful \\ and beneficial effects of \\ chemical cnange, data \\ collection by satellites \\ harm and benefits, \\ greenhouse effect and \\ ozone depletion, etc. \\ Grade 10B \\ Science \\ Grade $10 G$ \\ Science \\ Fibres and Fabrics Paper making, recycling. \\ Toxic vapours from \\ synthetics. \\ skin, sun, and \\ Eyes \\ Ultra violet radiation, \\ sunburn, skin cancer and \\ eye damage. \\ Attitudes, skill and \\ knowledge related to \\ balance within and \\ interrelationships among \\ components in the \\ environment. Role of fir \\ in forest regeneration, \\ plant and animal \\ import/export \\ regulations, habitat
}


The Functioning Animal

Environmental Chemistry

Magnetism and Electricity

Wise use of Resources

Minerals and Mining

Terrestrial and Aquatic Ecosystems

Grade $10 \mathrm{G}$ Environmental Science destruction, population management, long term effects of chemicals in ecosystems.

Effects of food additives, airborne pollution, pesticides, and hormones on health.

Air and water pollution and their control eg. acid rain, thermal pollution, and soil leaching.

Electrostatic precipitation of pollutants, electricity and environment.

Energy: types, sources, and measurement. Energy systems, industrial processes and energy consumption, conserving energy and resources.

Pollution from refining and purification.

Forest, farm and aquatic ecosystem function and management.

Urban and rural plant applications, tropical rainforest and farmland depletion.

Animal Adaptations

Environmental degradation and animal survival.

Soil erosion and misuse, fertilizer and pesticide pollution. 
Energy:

Interaction and Dependence

Ecosystems

Horticulture I

Forestry I

Living with insects

Agricultural Crop Science

Grade 10A Science
Interactions

Organisms and their External Environment

Organisms and their Internal Environment

Heat

Applied Chemistry

Magnetism and Electricity
Alternate energy sources, public transit vs cars, and other solutions. Acid rain, air pollution and climatic change.

Abiotic and biotic factors that control ecosystems. Natural balance and man-made disruptions. Conservation, agroeconomy, pets, gardening.

Alternate methods of food production.

Reforestation, clear cutting, pests and pesticide problems.

Pests, pesticides and alternate methods of control.

Wise use of agricultural land.

Study of ecology.

Environmental Issues eg. composting, conservation.

Organisms and environmental diversity. Environmental alteration. The impact of man made change eg. species extinction. Sustainable development.

Toxic substances.

Thermal, nuclear and carbon dioxide pollution.

Chemical disposal.

Acid rain, radioactive waste, thermal pollution. 
Waste Management Liquid and Solid waste. Wastes and the environment. Hazardous waste. Waste management.

Grade $10 G$ Applied Biology
Grade $11 G$

Applied Chemistry
Respiratory and Cardiovascular Systems

Waste Management

Home Gardening

skin

Humans and the Environment
Air pollution and respiratory diseases and allergies.

Water pollution, chemical pollution, water purification, air pollution, garbage, waste treatment, recycling.

Organic gardening anc chemical reduction.

Skin disorders caused by the sun.

Population growth, food consumption, waste disposal and recycling, global ecological issues. eg. rainforest depletion, acid rain, arable land depletion. Local environmental issues.

Quality and pollutant control.

Analysis

The Structure of Matter

Radioactive materials and health.

Properties of

Substances

Chemicals in Action

Chemical spills, salt damage

Synthesis of chemicals and pollution. eg. Acid rain.

Acids and Bases
Effects of acid rain on the environment. 
$11 A$

Biology

Grade 11A

Chemistry

Grade 12A

Physics
The World of

Carbon Chemistry

Nuclear Chemistry

Vascular Plants

Gasoline Additives (lead) Greenhouse Effect

Ozone depletion

Radiation

Role of plant hormones in weed control, deforestation.

Bacteria and Viruses

Nitrogen Fixation and decomposition of organic material.

Vertebrate Gas

Exchange Systems

Pollution and Respiratory disease.

The impact of science on

Selected Issues.
Matter

Gases

Chemical Reactions

Solutions

Industry and Society

Mechanics

Electricity

Electromagnetism
Separation of substances and pollution control. oil spills, radiation.

Carbon dioxide and the environment.

Pollution from chemical production.

Water pollution and purification. Acid rain.

Environmental problems associated with chemical industry.

Determination $\mathrm{C}_{i}$ the amount of energy needed to maintain some aspect of lifestyle. Wind and water power.

Resource depletion, acid rain, thermal pollution.

Power transmission lines and the environment. 
Sound

Nuclear Physics

Plant Physiology and Photosynthesis

Genetics

The Theory of

Evolution

Ecology

Organic Chemistry

Energy and Rates

in Chemical

Reactions

Equilibrium

Applications

Redox and Electrochemistry

OAC

Physics
Momentum and Energy

Electrostatics
Noise pollution.

Nuclear waste and radiation.

Environmental factors

and photosynthesis. Role of understanding photosynthesis in conservation and cultivation.

Development of new hybrids to enhance global food production.

Role of specialization in development of new varieties of domestic plants and animals.

Basic ecological concepts Human ecology and environmental ethics.

DDT, PCB's and other toxic organics.

Gasification of Coal, alteration of octane ratings with lead etc.

Acid Rain solutions.

Benefits and harards of storing energy in electrochemical cells.

Role of physics in development of more energy efficient and environmentally sound machines.

Electrostatic air cleaners. 
OAC

Science in

Society
Current issues in Science

\author{
Nature of Science \\ Nature of \\ Technology \\ Humans and the \\ Environment
}

B. THE GEOGRAPHY CURRICULUM
Resources

Environments in The News

River systems

Fragile

Environments
Role of scientific literacy in making sound decisions in society.

Impact of technology on environment.

Concern for the environment, pollution, population, resource depletion, energy, impact of military technology. Solutions.

Fertilizers and pesticides. Chemical warfare. Toxic waste, chemicals in the water supply.

Topic/Concept

Community development, industrial development, deforestation, drainage, planned urban expansion.

Non-renewable and renewable.

Environmental balance in developing primary industries.

Natural disasters. Man's waste leading to disasters.

Conflicts over water use.

Ecological disruptions, ecosystem, human activities influencing ecosystems, global

concerns. 
Grade 8

Patterns in

Human

Geography

Grade 10

Geography

of Canada
Patterns in our

Community

Manufacturing

People in Transition
Improvement of a local environment. Recycling of wastes by a community. Investigate cause/effect relationships in the local environment.

Production of a good/wastage involved in process and possible damage.

Consider how people have adapted to their environment, consider how other cultures perceive the use of the environment.

Physical Diversity

Relationship between people and their environment. Human interaction with the environment.

Natural Resources

Renewable and nonrenewable resources. Acid rain. Urban expansion.

Reasons for Canadians to conserve natural resources. Use of resources such as wilderness areas and provincial parks.

Urban Canada

Problems associated with urban sprawl, waste disposal.

Locality studies Examine current examples of conflicts in the community that involve such matters as land uses, transportation and waste disposal. 


\begin{tabular}{|c|c|c|}
\hline $\begin{array}{l}\text { Grade } 11 / 12 \\
\text { Physical } \\
\text { Geography }\end{array}$ & $\begin{array}{l}\text { An Overview of } \\
\text { Physical Geography }\end{array}$ & $\begin{array}{l}\text { Develop curiosity about } \\
\text { the immediate and global } \\
\text { environments. } \\
\text { Interaction between } \\
\text { people and their } \\
\text { environment. }\end{array}$ \\
\hline & $\begin{array}{l}\text { Vegetation and } \\
\text { soils }\end{array}$ & $\begin{array}{l}\text { Concern about the } \\
\text { conservation and wise use } \\
\text { of vegetation and soils. } \\
\text { l"egetation as a life- } \\
\text { support system. }\end{array}$ \\
\hline & $\begin{array}{l}\text { Integrative } \\
\text { studies }\end{array}$ & $\begin{array}{l}\text { Human use of one or more } \\
\text { distinctive environments, } \\
\text { major emphasis expected, } \\
\text { and unforseen } \\
\text { consequences of human } \\
\text { intervention }\end{array}$ \\
\hline \multirow{4}{*}{$\begin{array}{l}\text { Grade } 11 / 12 \\
\text { Human } \\
\text { Geography }\end{array}$} & $\begin{array}{l}\text { An Overview of } \\
\text { Human Geography }\end{array}$ & $\begin{array}{l}\text { Human uses and abuses of } \\
\text { the natural environment. }\end{array}$ \\
\hline & $\begin{array}{l}\text { Population and } \\
\text { Environment }\end{array}$ & $\begin{array}{l}\text { Investigate environmental } \\
\text { problems associated with } \\
\text { the rapid growth of the } \\
\text { human population. } \\
\text { Effect of technological } \\
\text { advances or the human } \\
\text { environmert. }\end{array}$ \\
\hline & Global Village & $\begin{array}{l}\text { Control of technological } \\
\text { advancement. }\end{array}$ \\
\hline & $\begin{array}{l}\text { Changes, Trends, } \\
\text { Planning }\end{array}$ & $\begin{array}{l}\text { Identify one specific } \\
\text { trend in the local } \\
\text { community involving the } \\
\text { use of space or } \\
\text { resources. }\end{array}$ \\
\hline \multirow[t]{2}{*}{$\begin{array}{l}\text { Grade } 11 / 12 \\
\text { Regional } \\
\text { Geography }\end{array}$} & $\begin{array}{l}\text { Selected Regional } \\
\text { studies }\end{array}$ & $\begin{array}{l}\text { Natural resources, } \\
\text { political response to } \\
\text { community's needs. }\end{array}$ \\
\hline & Issues and Trends & $\begin{array}{l}\text { Environmental } \\
\text { degradation, proposed } \\
\text { development trends. }\end{array}$ \\
\hline
\end{tabular}


Planning

Grade 11/12 Urbanization

Urban studies
Environmental purposes. The disposal of toxic wastes.

The regulation of wastes.

Effect of urbanization on our neighbourhoods. Effects of urbanization on lifestyle.

Internal structure of city

Urban Economy

Integrative studies
Investigate conflicts that develop over the use of urba.n space.

Economic development of the natural environment.

A local planning issues, taking into consideration the view points of local planners and residents. Urban politics. Waste disposal. Quality of life.

Environmental Environment Ecosystems Studies $^{2}$

Ecosystems and Resources

Built Environments

Changing Environments

Preservation, Conservation and Environmental Management Issues

OAC

World Issues

Geographic Approaches to World Issues
Analysis of the effects

of an issue under study:

a) on the environment; and b) on the people.

2 This course was develope in 1988 when the geography curriculum was reviewed (Onitario Ministry of Education 1988f). The entire course focuses on the environment. 
Environmental Issues

Economic and

Resource Issues
OAC

Canada

Environment and Economy
Environmental Systems Important to Canada

Patterns of Population Composition and distribution in Canada

Urban and Regional Systems
Role of technology in modifying and managing environments.

Human intervention. Waste disposal collective. Responsibility in environment. Acid rain, greenhouse effect.

Study specific environmental concerns that are seen as issues.

Energy: Production and consumption. Waste management. Production of, trade in and consumption of key commodities.

Implications of acid precipitation for various regions, trans-border exchanges of environmental elements.

Environmental and social issues arising from the concentration of population in urban centred regions.

Environmental issues related to urban and regional studies.

Environmental

Systems and Resource Management 
C. THE FAMILY STUDIES CURRICULUM

$\begin{array}{ll}\text { Course } & \text { Unit } \\ \text { Grade } 7 & \text { Families of the } \\ \text { Family } & \text { Future } \\ \text { Studies } & \end{array}$

Families in our Community

$\begin{array}{ll}\begin{array}{l}\text { Grade } 8 \\ \text { Family } \\ \text { Studies }\end{array} & \text { Clothing } \\ \begin{array}{l}\text { Grade } 9 \\ \text { World of Food }\end{array} & \begin{array}{l}\text { Sound Food } \\ \text { Choices }\end{array} \\ & \begin{array}{l}\text { Food and Family } \\ \text { Relationships }\end{array} \\ & \text { Families and the } \\ \text { Global Food Supply }\end{array}$

Grade 10

Creative

Fashion clothing

Management

Clothing as an Expression of Lifestyle
Topic/Concept

Changing needs and practices of procurement and preparation (packaging and waste).

Environmental concerns. wise food choices and recycling.

Advantages of being able to make repairs.

Recycling clothes.

Safe handling of food to prevent waste.

Fast food (packaging and garbage).

Current food crises. Future trends in food technology.

The use of recycled items. The renovation and recycling of clothing.

Current ecological concerns: water pollution, air pollution, energy conservation. How waste products from washing, dyeing, and bleaching clothes, and from detergents and petroleum based cleaning solvents affect the environment in which the family lives. The envirormental factors that cauge deterioration 
Grade 11

Parenting

Grade 12

Housing
Parenting

Throughout the

Life Cycle

Child Development

Within

Contemporary

Families of the fabrics used in clothing.

How various factors affect clothing choices: concern for health, cleanliness, and the desire for an unpolluted environment.

Transmission of values, knowledge and awareness of environmental issues. cloth vs. disposable diapers.

Safety considerations: the family dwelling, furniture, clothing, toys, toxic substances, and other items that can be harmful to children.

Special considerations:

Housing: Meeting the Needs of Families pollution, demands on the water or electrical

supply.

Types of community services available for recycling.

Factors affecting family housing: use, disposal of waste, advances and changes in technology and energy conservation. The effect on housing and family life of laws and regulations pertaining to pollution, and the conservation of energy. Energy conservation.
Independent Living
Food labelling and packaging. waste disposal.

Nutrition 
OAC

Families in

Canadian

Society
Families with

Young Children

Families with

Adolescents
Waste disposal (diapers).

Factors influencing food selection (packaging and waste).

Water and electrical conservation. 
APPENDIX $\mathrm{K}$

ENVIRONMENTAL QUESTIONNAIRE ADMINISTERED BY

THE ENVIRONMENTAL ACTION AD HOC COMMITTEE

ENVIRONMENT QUESTIONNAIRE

1. Is there an environmental club in your school?

Yes No

a) If yes, how many members?

b) What are its major activities?

2. Does your school have a recycling program?

Yes

No

If yes, do you recycle

$$
\begin{aligned}
& \text { fine paper } \\
& \text { cans } \\
& \text { bottles } \\
& \text { newspapers }
\end{aligned}
$$

Yes No

Yes No

Yes No

Yes No

3. Are teachers encouraging litterless lunches? Yes No

4. a) Are you aware that the Carleton Roman Catholic School Board has established an Environmental Action Committee composed of Trustees, students, parents, and Teachers?

Yes No

b) Do you have any suggestions for this committee?

Yes No 
5. Please list examples of specific environmental projects and topics in your school's curriculum.

6. Are your students involved in outdoor environmental education activities?

Yes No

If yes please give examples.

7. a) Did your school participate in Earth Day - 1990?

Yes No

b) Will it be participating in

Earth Day - 1991?

Yes No

8. Does your school seek to avoid the use of disposable paper, plastic and styrofoam cups and plates?

Yes No

9. Does your school make use of nearby nature trails or outdoor areas?

Yes No

10. Please list below any comments or concerns. 


\section{BIBLIOGRAPHY}

Adams, Michael. 1992. Environics Corporation. Speech Broadcast on CBC Radio, April 17 at $12: 30 \mathrm{pm}$.

Baez, Albert. 1986. The Educational Challenge of the World Conservation strategy. In Environmental Challenges: Learning for Tomorrow's World, eds. Paul F. Wilkinson and Miriam Wyman, 49-62. London, ontario: The Althouse Press.

Baine, Richard P. 1991. A Survey of the status of Geography and Social studies in Canadian Elementary and Secondary Schools. The Operational Geographer 9 3: 6-11.

Bandhu, Desh and G.S. Aulakh. eds. 1981. Environmental Education. New Delhi: Indian Environmental Society.

Biswas, Margaret R. and Asit K. Biswas. 1982. Major requirements for environmental education. Environmental Conservation 9: 125-130.

Blackstone, William. 1980. Ethics and ecology. In Philosophy and Enyironmental Crisis, ed. William Blackstone, 16-42. Athens:University of Georgia Press.

Buethe, Chris and Jim Smallwood. 1987. Teachers' environmental literacy: Check and recheck, 1975 and 1985. The Journal of Environmental Education 18 (Spring): 39-42.

Brundtland, Gro Harlem. 1987. See Qur Common Future. 1987.

Carleton Roman Catholic School Board. 1989a. Kinutes of the Brard October 17, 1989. Nepean: Carleton Roman Catholic school Board.

Carleton Roman Catholic School Board. 1989b. Minutes of the Environmental Action Ad Hoc Committee November 21.1989. Nepean: Carleton Roman Catholic School Board.

Carleton Roman Catholic School Board. 1989c. Minutes of the Board December 19, 1989. Nepean: Carleton Roman Catholic School Board.

Carleton Roman Catholic School Board. 1990a. Carleton Roman Catholic School Board: Enrollment Figures 1990-1991. Nepear: Carleton Roman Catholic School Board.

Carleton Roman Catholic School Board. 1990b. Ecology and Applied Ecological Themes in the $K$ - OAC Curriculum. (Handed out at the Environmental Action Ad Hoc Committee 
October 22, 1990) Nepean: Carleton Roman Catholic School Board.

Carleton Roman Catholic School Board. 1991a. Welcome to the Board. Nepean: Carleton Roman Catholic School Board.

Carleton Roman Catholic School Board. 1991b. Realizing the vision: Touching Tomorrow Today: Mission statement and Goals. Nepean: Carleton Roman Catholic School Board.

Carleton Roman Cathoilc School Board. 1991c. Carleton Roman Catholic School Board: Policies and Procedures Manual (Section C: Programs, Sub-Section: General, subtect: Environmental Action). Nepean: Carleton Roman Catholic School Board.

Carleton Roman Catholic School Board. 1991d. Minutes of the Environmental Action Ad Hoc Committee March 25, 1921 . Nepean: Carleton Roman Catholic School Board.

Carleton Roman Catholic School Board. 1992. Minutes of the Buard March 3, 1992. Nepean: Carleton Roman Catholic School Board.

Carmody, John. 1983. Ecology and Religion: Toward a New Christian Theology of Nature. New York: Paulist Press.

Carson, Rachel. 1962. Silent Spring. Boston: Houghton Mifflin Company.

CIDA. 1986a. Canada, Canadians and the environment. Development Special Issue on the Environment (June): 5-8.

CIDA. 1986b. Environment and development: Which way now? Development Special Issue on the Environment (June): 46-49.

CIDA. 1986c. From Stockholm to ottawa. Development Special Issue on the Environment (June): 2-4.

Cole, Susan G. 1989. The Greening of the Curriculum: How four innovative teachers created cross-curricular approaches to environmental education. Education Forum 15 4: 19-23.

Cundiff, Brad. 1989. Reading, Writing and the Environment. Seasons 29 3: 16-19.

Cunningham, Harry A. 1989. Smug indifference to paternal guilt: An environmental message for the 908 . Education Manitoba 17 2: 36. 
Devall, William. A sense of Earth wisdom. The Journal of Environmental Education 16 (Winter): 1-3.

Disinger, John F. 1985. Current trends in environmental education. The Journal of Environmental Education

17 (winter): 1-3.

Dower, Nigel. 1989. What is environmental ethics? In Ethics and Environmental Responsibility, ed. Nigel Dower, 11-37. Aldershot: Avebury.

Dyas1, Hubert. 1977. International Cooperation in Environmental Education. In Environmental Education: Key Issues of the Future. Proceedings of the conference held at the college of Technology. Farnborough. Fngland, ed. David Hughes-Evans, 43-54. Oxford: Pergamon Press.

Government. of Canada. 1990a. Canada's Green Plan Ottawa: Printing Services, Canada Communication Group.

Government of Canada. 1990b. Canada's Green Plan: News Release. Ottawa: Printing Services, Canada Communication Group.

Ham, Sam H., and Daphne R. Sewing. 1987. Barriers to environmental education. The Journal of Environmental Education 19 (winter): 17-24.

Ham, Sam H., Mary H. Rellerget-Taylor, and Edwin E. Krumpe. 1987. Reducing Barriers to environmental education. The Journal af Environmental Education 19 (Winter): 2542 .

Hammill, Roger. 1990. Take aim for environmental education. Teacher 3 2: 16.

Hughes-Evans, David. ed. 1977. Environmental Education: Key Issues of the Future. Proceedings of the conference held at the college of Technology, Farnborough. England. oxford: Pergamon Press.

Hungerford, Harold R., and Trudi L. Volk. 1990. Changing learning behavior through environmental education. The Journal of Environnental Education 21 (Spring): 8-21.

Istance, David. 1991. What Changes for Education? The OECD Observer 168 (February): 39-42.

Johnston, R.J. 1988. Writing geographically. In Research in Human Geography: Introductions and Investigations, ed. John Eyles, 174-197. Oxford: Basil Blackwell Ltd. 
Kelly-Laine, Kathleen. 1990. The Environment at School. The OECD Qbserver 165 (August): 13-16.

Kelly, P.J. 1977. What do we really mean by environmental education? In Environmental Education: Key Issues of the Future. Proceedings of the conference held at the collage of Technology, Farnbourough, Fngland, ed. David HughesEvans, 61-66. Oxford: Pergamon Press.

Kirk, John J. 1986. The World Conservation Strategy: The Key to Survival and the Nucleus for Environmental Education. In Environmental Challenges: Learning for Tomorrow's World, eds. Paul F. Wilkinson and Miriam Wyman, 37-48. London, Ontario: The Althouse Press.

Lovelock, John E. 1979. Gaia: A new look at life on Earth. Oxford: Oxford University Press.

Ludlow, Robin. 1989. With God on our side. Ottawa citizen. Special Section on the Environment (A Southam Environment Project) october 7: 21.

Matthews, Eric. 1989. The metaphysics of environmentalism. In Ethics and Environmental Responsibility, ed. Nigel Dower, 38-56. Aldershot: Avebury.

McIlroy, Anne and Margaret Munro. 1989. The Best of Times. ottawa citizen. Special Section on the Environment (A Southam Environment Project) October 7: 3 .

McLellan, Michael. 1990. Ecocentre Activity Package. Nepean: Carleton Board of Education.

Miller, G. Tyler Jr. 1982. Living in the Environment. Belmont, California: Wadsworth Publishing Company.

Munro, Margaret. 1989. Learning to Live With Less. Qttawa Cltizen. Special section on the Environment (A Southam Environment Project) October 7: 4 .

Neumann, Karl. 1987. Quantitative and qualitative approaches in educational research - Problems and examples of controlled understanding through interpretive methods. International Review of Education 332 : 159-170.

Nicholson, E.M. 1977. Keynote Address. In Environmental Education: Key Issues of the Future. Proceedings of the Conference held at the college of Technology. Farnborough, England, ed. David Hughes-Evans, 3-8 . Oxford: Pergamon Press. 
Ontario Ministry of Education. 1975. Circular P1J1:

Provincial curriculum Policy for the Primary and Junior pivisions of the public and separate schools of ontario: The Formative Years. Toronto: Ministry of Education, ontario.

Ontario Ministry of Education. 1986a. Curriculum Guidelines: Dramatic Arts: OAC: 1986. Toronto: Queen's Printer for Ontario.

Ontario Ministry of Education. 1986b. Curriculum Guideline: History and Contemporary studies: Part A: Policy and Program Considerations: 1986. Toronto: Queen's Printer for Ontario.

Ontario Ministry of Education. 1987a. Curriculum Ideas for Teachers: Discover Ontario Through the Road Map (second edition). Toronto: Queen's Printer for ontario.

Ontario Ministry of Education. 1987b. Curriculum Guideline: Science: Intermediate and Senior Divisions, 1987: Part 1: Proaram Qutline and Policy. Toronto: Queen's Printer for Ontario.

Ontario Ministry of Education. 1987c. Curriculum Guideline: Science: Intermediate and Senior Divisions, 1987: Part 2: Science: Grades 7 and 8. Toronto: Queen's Printer for ontario.

Ontario Ministry of Education. 1987d. Curriculum Guideline: Science: Intermediate and Senior Divisions, 1987: Part 3: Science: Grades 9 and 10, General Level. Toronto: Queen's Printer for Ontario.

Ontario Ministry of Education. 1987e. Curriculum Guideline: Science: Intermediate and Senior Divisions, 1987: Part 4: Science: Grades 9 and 10. Advanced Level. Toronto: Queen's Printer for Ontario.

Ontario Ministry of Education. 1987f . Curriculum Guideline: Science: Intermediate and Senior Divisions, 1987: Part 5: Science: Grades 9 and 10, Basic Level. Toronto: Queen's Printer for Ontario.

Ontario Ministry of Education. 1987g. Curriculum Guideline: Science: Intermediate and Senior Divisions, 1987: Part 12: Biology: Grade 11, Advanced Level, and the oAC. Toronto: Queen's Printer for Ontarin.

Ontario Ministry of Education. 1987h. Curriculum Guideline: Science: Intermediate and Senior Divisions, 1987: Part 13: Chemistry: Grade 11, Advanced Level, and the 
OAC. Torcnto: Queen's Printer for Ontario.

Ontario Ministry of Education. 1988a. Science is Happening Here: A Policy Statement for science in the Primary and Junior Divisions. Toronto: Queen's Printer for ontario.

Ontario Ministry of Education. 1988b. Geography: Intermediate and Senior Divisions, 1988: Curriculum Guideline: Part A: Policy and Program Expectations. Toronto: Queen's Printer for Ontario.

Ontario Ministry of Education. 1988c. Geography: Intermediate and Senior Divisions, 1988: Curriculum Guideline: Part B: Planning at the Local Level. Toronto: Queen's Printer for Ontario.

Ontario Ministry of Education. 1988d. Geography: Intermediate and Senior pivisions, 1988: Curriculum Guideline: Part C: The Intermediate Division Proaram. Toronto: Queen's Printer for Ontario.

Ontario Ministry of Education. 1988e. Geography: Intermediate and Senior Divisions, 1988: Curriculum Guideline: Part D: The Senior Division Program, Revised Courses. Toronto: Queen's Printer for Ontario.

Ontario Ministry of Education. $1988 \mathrm{f}$. Geography: Intermediate and Senior Divisions, 1988: Curriculum Guideline: Part F: The Senior Division Program, New Courses. Toronto: Queen's Printer for ontario.

Ontario Ministry of Education. $198 \mathrm{Bg}$. Geography: Intermediate and Senior Divisions, 1988: Curriculum Guideline: Part F: The Senior Division Program, ontario Academic Courses. Toronto: Queen's Printer for Ontario.

Ontario Ministry of Education. 1988h. Curriculum Guideline: Science: Intermediate and Senior Divisions, 1988: Part 6: Science: Grades 11 and 12 , Basic Level. Toronto: Queen's Printer for Ontario.

Ontario Ministry of Education. 1988i. Curriculum Guideline: Science: Intermediate and Senior Divisions, 1988: Part 7: Environmental Science: Grades 10 to 12 , General Level. Toronto: Queen's Printer for Ontario.

Ontario Ministry of Education. 1988j. Curriculum Guideline: Science: Intermediate and Senior Divisions, 1988: Part 8: Environmental Science: Grades 10 and 12. Advanced Level. Toronto: Queen's Printer for Ontario. 
Ontario Ministry of Education. 1988k. Curriculum Guideline: Science: Intermediate and Senior Divisions, 1988: Part 9: Applied Biology and Applied Chemistry: Grade 11, General Level. Toronto: Queen's Printer for ontario.

Jntario Ministry of Education. 19881. Curriculum Guideline: Science: Intermediate and Senior Divisions, 1988: Part 11: Geology: Grade 12, General and Advanced Levels. Toronto: Queen's Printer for Ontario.

Ontario Ministry of Education. $198 \mathrm{~cm}$. Curriculum Guideline: Science: Intermediate and Senior Divisions, 1988: Part 14: Physics: Grade 12, Advanced Level, and the OAC. Toronto: Queen's Printer for Ontario.

Ontario Ministry of Education. 1988n. Curriculum Guideline: Science: Intermediate and Senior Divisions, 1988: Part 15: Science in Society: OAC. Toronto: Queen's Printer for Ontario.

Ontario Ministry of Education. 19880. Curriculum Management: Resource Guide: 1988. Tcronto: Queen's Printer for Ontario.

Ontario Ministry of Education. 1989a. Ontario Schools: Intermediate and Senior Divisions (Grades 7-12/0ACs): Program and Diploma Requirements. Toronto: Queen's Printer for Ontario.

Ontario Ministry of Education. 1989b. Curriculum Guideline: Science: Intermediate and Senior Divisions, 1989: Part 10: Applied Physics and Technological science: Grade 12, General Level. Toronto: Queen's Printer for Ontario.

Ontario Ministry of Education. 1991a. Directory of Education 1990/1991. Toronto: Queen's Printer for Ontario.

Ontario Ministry of Education. 1991b. Science in Primary and Junior Education: A Report of Progress: 1991. Toronto: Queen's Printer for Ontario.

Ontario Ministry of Education. 1991c. Food and Nutrition Sciences: Curriculum Guideline: Senior Division: 1991. Toronto: Queen's Printer for Ontario.

Qttawa Citizen. 1989. Innovators. Ottawa Citizen. Special Section on the Environment (A Southam Environment Project) October 7: 3 . 
our Common Future: World Commission on Environment and Development. 1987. By Gro Harlem Brundtland, Chairman. Oxford: Oxford University Press.

Papadopulos, George S. 1991. An Educational Agenda for the '90s. The OECD Observer 168 (February): 36-38.

Pemberton, Dixie Ann. 1989. Definitional problems for environmental education and graphic education. The Journal of Environmental Educition 21 (Fall): 5-14.

Robottom, Ian. 1985. Evaluation in environmental education: Time for a Change in perspective. The Jcurnal of Environmental Fducation 17 (Fall): 31-36.

Rule, Jim and Dawn Paxton. 1991. Ecologically speaking: students can make a difference. ontaris. Public school Teachers' Federation News 5 3: 21.

Saveland, Robert N. ed. 1976. Handbook of Environmental Education with International Case Studies. London: John wiley and Sons.

Saveland, Robert N. 1976. Perspectives. In Handbook of Environmental Education with International case studies, ed. Robert N. Saveland, 1-26. London: John wiley and Sons.

Schneider, Dan. 1991. Classrooms without walls: Environmental education helps students turn their enthusiasm into action. Canadian Geographic 111 4: 66-73.

Simpson, Patricia R. et.al. 1989. A survey concerning teachers' perceptions of the importance of SRSI issues. The Journal of Environmental Education 21 (Fal1): 31-37.

Smith, Lorne R. 1991. Ontario Ministry of Education: Environmental Education: Summary of curciculum: $K$ to OAC. Toronto: Curriculum Policy Development Branch, Ontario Ministry of Education (unpublished).

Smith, Pat. 1990. How Can I Make a Difference? Nepean: Carleton Board of Education.

Sprinthall, Norman A. and Richard C. Sprinthall. 1987. Educational Psychology: The Developmental Approach. New York: Random House.

Swan, James and Stapp, William eds. 1974. Environmental Education: Strategies Toward a More Livable Future. New York: Halsted Press Division, John Wiley and Sons. 
Thomas, Ian G. 1989. Evaluating environmental education programs using case studies. The Journal of Environmental Education 21 (winter): 3-8.

Timmerman, Peter. 1986. Is it Possible to Teach Environmental Ethics. In Environmental Challenges: Learning for Tomorrow's World, eds. Paul $F$. Wilkinson and Miriam Wyman, 75-88. London, Ontario: The Althouse Press.

UNESCO. 1976. The Belgrade Charter. Connect I (January): 1-9.

UNESCO. 1980. Environmental Education in the light of the Tbilisi conference: Education on the move. Paris: UNESCO.

UNESCO. 1981. Interdisiplinarity in Environmental Education. connect VI (September): 1-2.

UNESCO and UNEP. 1987. International strategy for Action in the Field of Environmental Education and Training for the 1990's. Paris: UNESCO and UNEP.

Vivian, V. Eugene. 1973. Sourcebook for Environmental Education. Saint Louis: The C.V. Mosby Company.

Wals, Arjen E.J. 1990. Caretakers of the environment: A global network of teachers and students to save the Earth. The Journal of Environmental Education 21 (Spring): 3-7.

White, Gilbert F. 1986. The meaning of the environmental crisis. In Vol. 1. Geography, Resources, and Environment: Selected Writings of Gilbert $F$. White, eds. Robert Kates and Ian Burton, 278\%290. Chicago: The University of Chicago Press.

Wilkinson, Paul F. and Miriam Wyman. eds. 1986. Environmental Challenges: Learning for Tomorrow's World. London, Ontario: The Althouse Press.

Yin, Robert K. 1981. The Case Study Crisis: Some Answers. Administrative Science Quarterly 26 (March): 58-65.

Yin, Robert K. 1984. Case Study Research. Beverly Hills: Sage. 
INTERVIEWS

Allan, Frank. Ottawa Board of Education. May 6, 1991.

Armstrong, Mary. Carleton Roman Catholic School Board. May 13, 1991.

Armstrong, Pat. Carleton Roman Catholic School Board. May 30, 1991.

Billington, Charles. Rideau Valley Conservation Authority. May 1, 1991.

Brasset, Andrea. Carleton Roman Catholic School Board. March 2, 1991 and April 14, 1991.

Brasset, Maureen. Carleton Roman Catholic School Board. April 14, 1991, May 1, 1991 and April 8, 1992.

Broom, Garry. Carleton Board of Education. January 10, 1991.

Brousseau, Karen. Carleton Roman Catholic School Board. May 14, 1991.

Cobb, Shannon. Carleton Roman Catholic School Board. May 21, 1991.

D'Amico, Vic. Carleton Roman Catholic School Board. April 11, 1991 and May 14, 1991.

Davis, Mike. Carleton Roman Catholic School Board. May 21, 1991.

Delaney, Val. Carleton Roman Catholic School Board. May 13, 1991.

Des Lauriers, Camille. Carleton Roman Catholic School Board. May 21, 1991.

Duggan, Frank. Carleton Roman Catholic School Board. May 17, 1991 and May 24, 1991.

Duguay, Alain. Carleton Roman Catholic School Board. May 29, 1991.

Duquette, Cheryl. University of ottawa: Faculty of Education. March 21, 199?.

Durvine, June. Ontario Ministry of Education. April 10, 1992. 
Farrwell, Monique. Carleton Roman Catholic School Board. May 29, 1991 .

Fillion, Bernard. Carleton Roman Catholic School Board. May 29, 1991.

Fransham, Richard. Carleton Roman Catholic School Board. May 24, 1991.

Haffner, Paula. Carleton Roman Catholic School Board. May 24, 1991.

Hailey, Jill. Carleton Roman Catholic School Board. May 24, 1991.

Harrington - Veryard, Cathy. Carleton Roman Catholic School Board. May 29, 1991.

Harrison, Gordon. The Common Heritage. January 15, 1991.

Hutchinson, Vance. Carleton Roman Catholic School Board. May 24, 1991.

Ilgunas, Fran. Carleton Roman Catholic School Board. May 21, 1991.

Kerr, Wayne. University of Ottawa: Faculty of Education. March 21, 1991.

Klasser, Elizabeth. Carleton Roman Catholic School Board. May 14, 1991.

Lamarche, Art. Carleton Roman Catholic school Board. May 1, 1991 and May 30, 1991.

Lamourie, David. Carleton Roman Catholic School Board. May 29, 1991.

Lineger, Peter. Carleton Roman Catholic School Board. May 24, 1991.

Lemoine, Barry. Carleton Roxan Catholic School Board. May 24, 1991.

Mackay, Lee. Carleton Roman Catholic School Board. May 29, 1991.

Metivir, Marc. Ottawa-Carleton French Language School. Board. January 12, 1991.

Murphy, Mary. Carleton Roman Catholic School Board. May 21, 1991. 
Ostafichuk, William. Carleton Roman Catholic School Board. May 9, 1991.

Pat-Kelly, Mary. Carleton Roman Catholic School Board. May 13, 1991.

Patrick, Anne. Carleton Roman Catholic School Board. May 14, 1991.

Provincal, Jason. Carleton Roman Catholic School Board. May 24, 1991.

Purdy, Mike. Ottawa Board of Education. January 23, 1991.

Schreider, Kim. Carleton Roman Catholic School Board. May 21, 1991.

Shannon, John. Carleton Roman Catholic School Board. May 21, 1991.

Smith, Lorne. Ontario Ministry of Education. March 31, 1992 and April 15, 1992.

Smith, Pat. Carleton Board of Education. May 6, 1991.

Touchette, claudette. Carleton Roman Catholic School Board. April 13, 1992 .

Walker, Trevor. Carleton Roman Catholic School Board. May 14, 1991.

Walsh, Cheryl. Carleton Roman Catholic School Board. May 29, 1991.

Wood, Murray. Ontario Ministry of Education. May 3, 1991. 

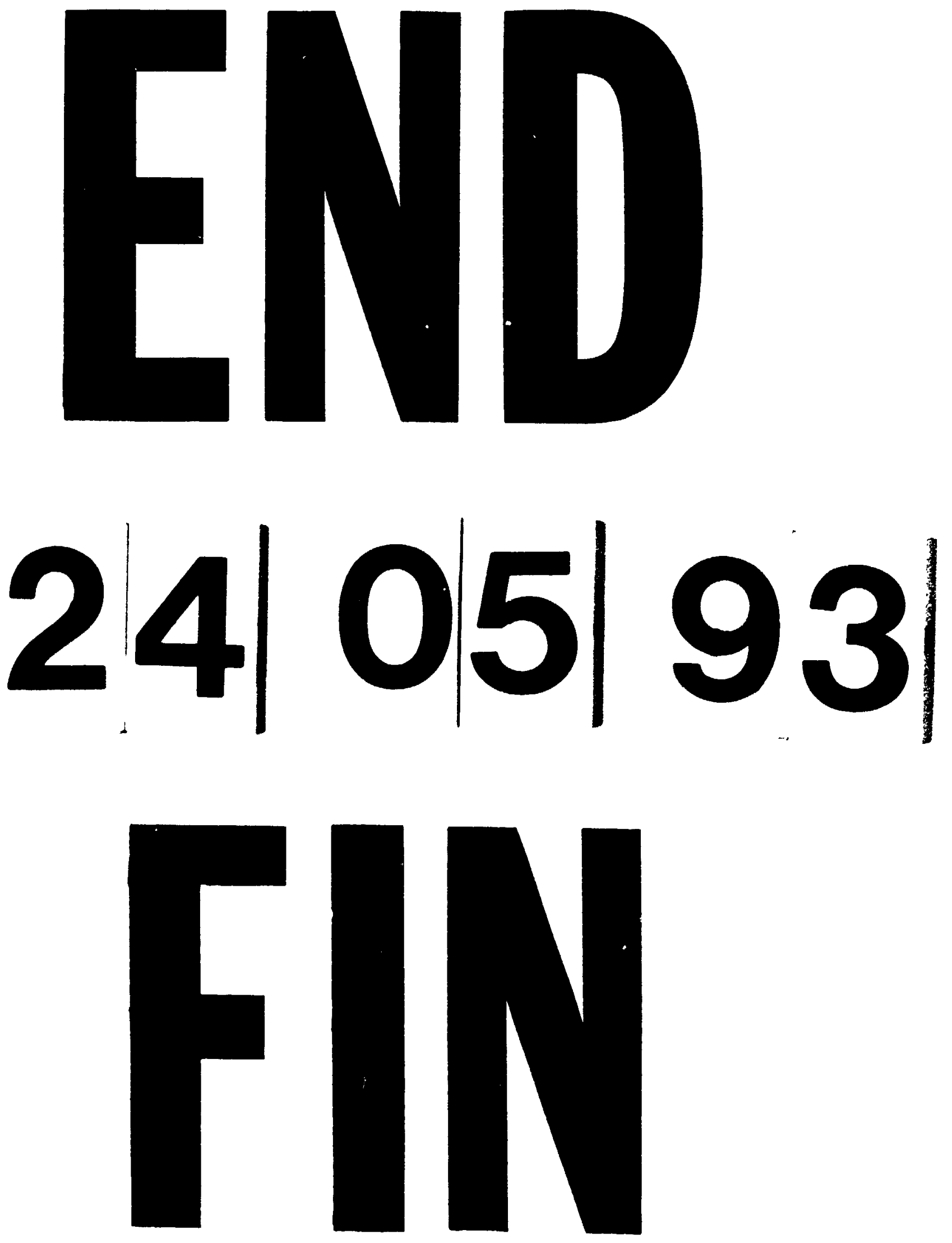